Cochrane Database of Systematic Reviews

\title{
Antibiotic prophylaxis to reduce respiratory tract infections and mortality in adults receiving intensive care (Review)
}

D'Amico R, Pifferi S, Torri V, Brazzi L, Parmelli E, Liberati A

D'Amico R, Pifferi S, Torri V, Brazzi L, Parmelli E, Liberati A.

Antibiotic prophylaxis to reduce respiratory tract infections and mortality in adults receiving intensive care.

Cochrane Database of Systematic Reviews 2009, Issue 4. Art. No.: CD000022.

DOI: 10.1002/14651858.CD000022.pub3.

www.cochranelibrary.com 
TABLE OF CONTENTS

HEADER 1

ABSTRACT

PLAIN LANGUAGE SUMMARY

BACKGROUND

OBJECTIVES

METHODS

RESULTS

DISCUSSION

Figure 1.

AUTHORS' CONCLUSIONS

ACKNOWLEDGEMENTS

REFERENCES

CHARACTERISTICS OF STUDIES

DATA AND ANALYSES

Analysis 1.1. Comparison 1 Topical plus systemic versus no prophylaxis, Outcome 1 Overall mortality.

Analysis 1.2. Comparison 1 Topical plus systemic versus no prophylaxis, Outcome 2 Mortality according to quality of allocation concealment.

Analysis 1.3. Comparison 1 Topical plus systemic versus no prophylaxis, Outcome 3 Mortality according to blinding of the studies.

Analysis 1.4. Comparison 1 Topical plus systemic versus no prophylaxis, Outcome 4 RTIs.

Analysis 1.5. Comparison 1 Topical plus systemic versus no prophylaxis, Outcome 5 RTIs according to quality of allocation concealment.

Analysis 1.6. Comparison 1 Topical plus systemic versus no prophylaxis, Outcome 6 RTIs according to blinding of the studies. ..

Analysis 2.1. Comparison 2 Topical versus control, Outcome 1 Overall mortality.

Analysis 2.2. Comparison 2 Topical versus control, Outcome 2 Mortality according to quality of allocation concealment. .........

Analysis 2.3. Comparison 2 Topical versus control, Outcome 3 Mortality according to blinding of the studies.

Analysis 2.4. Comparison 2 Topical versus control, Outcome 4 RTIs.

Analysis 2.5. Comparison 2 Topical versus control, Outcome 5 RTIs according to quality of allocation concealment.

Analysis 2.6. Comparison 2 Topical versus control, Outcome 6 RTIs according to blinding of the studies.

APPENDICES

WHAT'S NEW

HISTORY

CONTRIBUTIONS OF AUTHORS

DECLARATIONS OF INTEREST

SOURCES OF SUPPORT

INDEX TERMS 
[Intervention Review]

\section{Antibiotic prophylaxis to reduce respiratory tract infections and mortality in adults receiving intensive care}

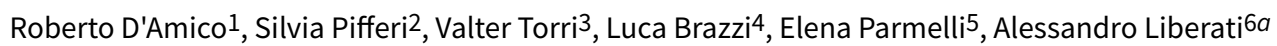

1Statistics Unit, Department of clinical and diagnostic medicine and public health, University of Modena and Reggio Emilia, Modena, Italy, University of Modena and Reggio Emilia, Modena, Italy. ${ }^{2}$ Policlinico San Matteo, Pavia, Milano, Italy. ${ }^{3}$ Laboratorio di Epidemiologia Clinica, Mario Negri Institute, Milano, Italy. ${ }^{4}$ Dipartimento di Scienze Chirurgiche, Microchirurgiche e Mediche, Università degli Studi di Sassari, Sassari, Italy. ${ }^{5}$ Department of Oncology, Hematology and Respiratory Diseases, University of Modena and Reggio Emilia,

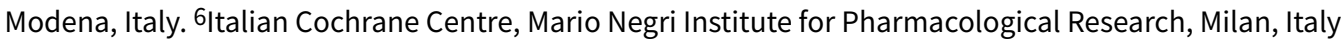

a Deceased

Contact address: Roberto D'Amico, Statistics Unit, Department of clinical and diagnostic medicine and public health, University of Modena and Reggio Emilia, Modena, Italy, University of Modena and Reggio Emilia, Via del Pozzo 71, Modena, 41121, Italy. roberto.damico@unimore.it.

Editorial group: Cochrane Acute Respiratory Infections Group Publication status and date: Edited (no change to conclusions), published in Issue 2, 2013.

Citation: D'Amico R, Pifferi S, Torri V, Brazzi L, Parmelli E, Liberati A. Antibiotic prophylaxis to reduce respiratory tract infections and mortality in adults receiving intensive care. Cochrane Database of Systematic Reviews 2009, Issue 4. Art. No.: CD000022. DOI: 10.1002/14651858.CD000022.pub3.

Copyright @ 2013 The Cochrane Collaboration. Published by John Wiley \& Sons, Ltd.

\section{A B S T R A C T}

\section{Background}

Pneumonia is an important cause of mortality in intensive care units (ICUs). The incidence of pneumonia in ICU patients ranges between $7 \%$ and $40 \%$, and the crude mortality from ventilator-associated pneumonia may exceed $50 \%$. Although not all deaths in patients with this form of pneumonia are directly attributable to pneumonia, it has been shown to contribute to mortality in ICUs independently of other factors that are also strongly associated with such deaths.

\section{Objectives}

To assess the effects of prophylactic antibiotic regimens, such as selective decontamination of the digestive tract (SDD) for the prevention of respiratory tract infections (RTIs) and overall mortality in adults receiving intensive care.

\section{Search methods}

We searched the Cochrane Central Register of Controlled Trials (CENTRAL) (The Cochrane Library 2009, issue 1), which contains the Cochrane Acute Respiratory Infections (ARI) Group's Specialised Register; MEDLINE (January 1966 to March 2009); and EMBASE (January 1990 to March 2009).

\section{Selection criteria}

Randomised controlled trials (RCTs) of antibiotic prophylaxis for RTIs and deaths among adult ICU patients.

\section{Data collection and analysis}

At least two review authors independently extracted data and assessed trial quality. 


\section{Main results}

We included 36 trials involving 6914 people. There was variation in the antibiotics used, patient characteristics and risk of RTIs and mortality in the control groups. In trials comparing a combination of topical and systemic antibiotics, there was a significant reduction in both RTIs (number of studies $=16$, odds ratio $(\mathrm{OR}) 0.28,95 \%$ confidence interval $(\mathrm{CI}) 0.20$ to 0.38 ) and total mortality (number of studies $=17$, OR $0.75,95 \% \mathrm{Cl} 0.65$ to 0.87 ) in the treated group. In trials comparing topical antimicrobials alone (or comparing topical plus systemic versus systemic alone) there was a significant reduction in RTIs (number of studies $=17$, OR $0.44,95 \% \mathrm{Cl} 0.31$ to 0.63 ) but not in total mortality (number of studies $=19$, OR $0.97,95 \% \mathrm{Cl} 0.82$ to 1.16 ) in the treated group.

\section{Authors' conclusions}

A combination of topical and systemic prophylactic antibiotics reduces RTIs and overall mortality in adult patients receiving intensive care. Treatment based on the use of topical prophylaxis alone reduces respiratory infections but not mortality. The risk of resistance occurring as a negative consequence of antibiotic use was appropriately explored only in one trial which did not show any such effect.

\section{PLAIN LANGUAGE SUMMARY}

\section{Antibiotics to help reduce mortality and respiratory infections in people receiving intensive care in hospital}

Infections acquired in intensive care units (ICUs) are important complications of the treatment of patients with very severe diseases who need ventilation (mechanical breathing support). Some people will die because of these infections. Considerable efforts have been made to evaluate methods for reducing this problem; one of these involves the use of antibiotics administered as preventative intervention, usually referred to as selective decontamination of the digestive tract (SDD). This review includes 36 studies involving 6914 patients treated in ICUs to investigate whether the administration of antibiotics prevents the development of infections. Antibiotics were administered in two different ways. In some studies antibiotics were applied both directly to the oropharynx via a nasogastric tube (topical) and intravenously (systemic). In other studies they were applied only topically. Our results show that when patients received the combination of topical plus systemic antibiotics there were less infections and deaths. When patients received only topical treatment there were less infections but the number of deaths was not changed. Although this treatment seems to work it is not widely used in clinical practice because there is concern about the possible development of antibiotic resistance (that is, bacteria become unresponsive to drugs). 


\section{B A C K G R O U N D}

\section{Description of the condition}

Infections acquired in the intensive care unit (ICU), especially pneumonia, are important complications of the treatment of critically ill patients, increasing morbidity and mortality. The incidence of pneumonia has been reported to vary from $7 \%$ to more than 40\% in ICU patients (Chevret 1996; Fagon 1996). The mortality rate for patients with ventilator-associated pneumonia (VAP) may exceed $50 \%$. Although not all deaths in patients with pneumonia are directly attributable to pneumonia, it has been shown to contribute to ICU mortality, independently of other factors that are also strongly associated with deaths in these patients (Fagon 1996). In a case-controlled study an increase in mortality of $27 \%$ attributable to pneumonia was evidenced in ventilated patients (Fagon 1996).

\section{Description of the intervention}

Considerable efforts have been made to evaluate methods for reducing respiratory tract infections (RTIs). One strategy involves the use of selective decontamination of the digestive tract (SDD). Different SDD protocols have been used in different trials and investigators often disagree on which is the most appropriate definition of SDD. Traditionally, SDD indicates a method designed to prevent infection by eradicating and preventing carriage of aerobic, potentially pathogenic micro-organisms from the oropharynx, stomach and gut. It consists of antimicrobials applied topically to the oropharynx through a nasogastric tube. In some trials systemic antibiotic therapy has been added in the first days after the patients' admission to prevent 'early' infections.

\section{How the intervention might work}

The use of oral non-absorbable antibiotics was first reported by Stoutenbeek (Stoutenbeek 1994) in an SDD protocol based upon a group of multiple trauma patients. The incidence of nosocomial (hospital-acquired) infection was reduced from $81 \%$ to $16 \%$ in a non-randomised comparison with an historical control group. Further studies tested the efficacy of SDD in ICU patients, with infection-related morbidity as the main endpoint. The results showed that SDD reduced infection but it was not clear whether there was a reduction in mortality.

Between 1991 and 2008 nine different systematic review and metaanalyses (D'Amico 1998; Heyland 1994; Hurley 1995; Kollef 1994; Nathens 1999; Redman 2001; Silvestri 2007; SDD Group 1993; Vanderbrouk-Gra 1991) on the effect of SDD on RTIs and mortality were published. Their results are summarised in the table below.

\begin{tabular}{|c|c|c|c|c|}
\hline SR & $\begin{array}{l}\mathbf{N}^{\circ} \text { of } \\
\text { studies }\end{array}$ & $\begin{array}{l}N^{\circ} \text { of pa- } \\
\text { tients }\end{array}$ & Mortality & RTIS \\
\hline $\begin{array}{l}\text { Vander- } \\
\text { brouk-Gra } \\
1991\end{array}$ & 6 & 491 & $\begin{array}{l}\text { Odds ratio (OR) } 0.70 \\
95 \% \text { confidence intervals }(\mathrm{Cl}) 0.45 \text { to } \\
1.09\end{array}$ & $\begin{array}{l}\text { OR } 0.12 \\
95 \% \mathrm{Cl} 0.08 \text { to } 0.19\end{array}$ \\
\hline
\end{tabular}

\begin{tabular}{|c|c|c|c|c|}
\hline $\begin{array}{l}\text { SDD Group } \\
1993\end{array}$ & 22 & 4142 & $\begin{array}{l}\text { OR } 0.90 \\
95 \% \mathrm{Cl} 0.79 \text { to } 1.04\end{array}$ & $\begin{array}{l}\text { OR } 0.37 \\
95 \% \mathrm{Cl} 0.31 \text { to } 0.43\end{array}$ \\
\hline $\begin{array}{l}\text { Heyland } \\
1994\end{array}$ & 24 & 3312 & $\begin{array}{l}\text { Risk ratio (RR) } 0.87 \\
95 \% \mathrm{Cl} 0.79 \text { to } 0.97\end{array}$ & $\begin{array}{l}\text { RR } 0.46 \\
95 \% \mathrm{Cl} 0.39 \text { to } 0.56\end{array}$ \\
\hline Kollef 1994 & 16 & 2270 & $\begin{array}{l}\text { Risk difference (RD) } 0.019 \\
95 \% \mathrm{Cl}-0.016 \text { to } 0.054\end{array}$ & $\begin{array}{l}\text { Pneumonia } \\
\text { RD } 0.145 \\
95 \% \mathrm{Cl} 0.116 \text { to } 0.174 \\
\text { Tracheobronchitis } \\
\text { RD } 0.052 \\
95 \% \mathrm{Cl} 0.017 \text { to } 0.087\end{array}$ \\
\hline $\begin{array}{l}\text { Hurley } \\
1995\end{array}$ & 26 & 3768 & $\begin{array}{l}\text { OR } 0.86 \\
95 \% \mathrm{Cl} 0.74 \text { to } 0.99\end{array}$ & $\begin{array}{l}\text { OR } 0.35 \\
95 \% \mathrm{Cl} 0.30 \text { to } 0.42\end{array}$ \\
\hline $\begin{array}{l}\text { D'Amico } \\
1998\end{array}$ & 33 & 5727 & $\begin{array}{l}\text { Topical plus systemic ( } 16 \text { trials; } 3361 \\
\text { pts) } \\
\text { OR } 0.80 \\
95 \% \mathrm{Cl} 0.69 \text { to } 0.93 \\
\text { Topical alone ( } 17 \text { trials; } 2366 \text { pts) } \\
\text { OR } 1.01 \\
95 \% \mathrm{Cl} 0.84 \text { to } 1.22\end{array}$ & $\begin{array}{l}\text { Topical plus systemic ( } 16 \text { trials; } 3361 \text { pts) } \\
\text { OR } 0.35 \\
95 \% \mathrm{Cl} 0.29 \text { to } 0.41 \\
\text { Topical alone ( } 17 \text { trials; } 2366 \text { pts) } \\
\text { OR } 0.56 \\
95 \% \text { Cl } 0.46 \text { to } 0.68\end{array}$ \\
\hline
\end{tabular}




\begin{tabular}{|c|c|c|c|c|}
\hline $\begin{array}{l}\text { Nathens } \\
1999\end{array}$ & 21 & $\begin{array}{l}\text { Not re- } \\
\text { ported }\end{array}$ & $\begin{array}{l}\text { Surgical patients } \\
\text { OR } 0.7 \\
95 \% \mathrm{Cl} 0.52 \text { to } 0.93 \\
\text { Medical patients } \\
\text { OR } 0.91 \\
95 \% \mathrm{Cl} 0.71 \text { to } 1.18\end{array}$ & NA \\
\hline $\begin{array}{l}\text { Redman } \\
2001\end{array}$ & $\begin{array}{l}\text { Not re- } \\
\text { ported }\end{array}$ & $\begin{array}{l}\text { Not re- } \\
\text { ported }\end{array}$ & NA & $\begin{array}{l}\text { Ventilator-associated pneumonia (VAP) } \\
\text { OR } 0.36 \\
95 \% \mathrm{Cl} 0.28 \text { to } 0.46\end{array}$ \\
\hline $\begin{array}{l}\text { Silvestri } \\
2007\end{array}$ & 51 & 8065 & $\begin{array}{l}\text { OR } 0.8 \\
95 \% \mathrm{Cl} 0.69 \text { to } 0.94\end{array}$ & NA \\
\hline
\end{tabular}

All studies assessing RTIs confirmed their statistically significant reduction, though the magnitude of the treatment effect varied from one review to another probably due to different numbers of studies and inclusion criteria among them. The estimated impact on overall mortality was less evident.

This is an update to the previous version published in The Cochrane Library which included trials published up to 2003.

\section{OB JECTIVES}

To determine whether antibiotic prophylaxis reduces RTIs and overall mortality in adult patients treated in ICUs.

Specifically, the main question left unanswered by existing randomised controlled trials (RCTs) and previous meta-analyses was whether different forms of antibiotic prophylaxis (that is, topical antimicrobials or a combination of topical and systemic drugs) are effective in reducing overall mortality.

\section{METHODS}

\section{Criteria for considering studies for this review}

\section{Types of studies}

RCTs on antibiotic prophylaxis for preventing RTIs and deaths in adult ICU patients.

\section{Types of participants}

Adult patients admitted to an ICU. Studies based on specific preselected types of patients (that is, patients undergoing elective oesophageal resection, cardiac or gastric surgery, liver transplant or suffering from acute liver failure) were excluded because these patients need co-interventions that may interact with the main treatment. Studies where the majority of patients $(>50 \%)$ did not undergo mechanical ventilation for more than 48 hours were also excluded. The characteristics of excluded studies are reported in the 'Characteristics of excluded studies' table.

\section{Types of interventions}

Available RCTs have been grouped into two categories, defined according to the type of antibiotic prophylaxis:
1. studies where a combination of systemic and topical antibiotics was tested against no prophylactic treatment (thereafter referred to as 'topical plus systemic versus no prophylaxis'); and

2. studies where the experimental treatment tested was a topical preparation applied in the oropharynx (thereafter referred to as 'topical versus control').

For further details about preparation and administration of antibiotic prophylaxis see the 'Characteristics of included studies' table.

In this latter category two RCT subgroups have been lumped together, that is, those where topical antibiotics were tested against an untreated control group and those where the combination of topical plus systemic drugs was compared with a protocol based on a systemic antimicrobial only.

Any topical or systemic antimicrobial combination (that is: type of drugs) was accepted, because there was no data to assume a difference in effect among the considered prophylactic treatments. This obviously does not mean that all topical and systemic regimens are truly equivalent, but simply reflects our pragmatic working assumption.

\section{Types of outcome measures \\ Primary outcomes}

Primary outcome measures considered for this review were RTIs and overall mortality.

No restriction was made on the type of RTIs considered, or on the RTIs diagnostic criteria chosen by the trialists. Both tracheobronchitis and pneumonia were acceptable. Pragmatically, both primary (diagnosed within 48 hours from admission) and acquired (diagnosed after 48 hours from admission) infections were considered, even though we used data on acquired infections (the most appropriate outcome to assess treatment effect) when both pieces of information were available. Mortality was evaluated at hospital discharge if this information was provided; otherwise mortality in ICU was used. 


\section{Search methods for identification of studies}

\section{Electronic searches}

We searched the Cochrane Central Register of Controlled Trials (CENTRAL) (The Cochrane Library 2009, issue 1); MEDLINE (January 1966 to March 2009); and EMBASE (January 1990 to March 2009).

MEDLINE was searched using the following search strategy in conjunction with the Cochrane Highly Sensitive Search Strategy for identifying randomised trials in MEDLINE: sensitivityand precision-maximising version (2008 revision); Ovid format (Lefebvre 2008). The same strategy was used to search CENTRAL and adapted to search EMBASE.com (see Appendix 1).

\section{MEDLINE (Ovid)}

1 exp Respiratory Tract Infections/

2 respiratory tract infection*.tw.

3 exp Pneumonia/

4 pneumon ${ }^{\star}$.tw.

5 (HAP or VAP).tw.

6 bronchopneumonia*.tw.

7 pleuropneumonia*.tw.

8 exp Bronchitis/

9 bronchit* $^{\star}$.tw.

10 bronchiolit $^{\star}$.tw.

11 exp Pharyngitis/

12 pharyngit*.tw.

13 Tracheitis/

14 tracheit ${ }^{\star} . t w$.

15 or/1-14

16 exp Intensive Care Units/

17 icu.tw.

18 exp Critical Care/

19 critical care.tw.

20 intensive care.tw.

21 burn unit ${ }^{\star}$. tw.

22 care unit*.tw.

23 recovery room ${ }^{\star}$.tw.

24 Critical Illness/

25 (critic $^{\star}$ adj ill*).tw.

26 exp Ventilators, Mechanical/

27 mechanical ventilat ${ }^{\star}$.tw.

28 ventilator $^{\star}$.tw.

29 Respiration, Artificial/

30 artificial respiration ${ }^{\star}$.tw.

31 respirator ${ }^{*} . t w$.

32 or/16-31

3315 and 32

34 Pneumonia, Ventilator-Associated/

3533 or 34

36 Antibiotic Prophylaxis/

37 exp Anti-Bacterial Agents/

38 antibiotic ${ }^{\star}$. tw

39 or/36-38

4035 and 39

\section{Searching other resources}

There were no language or publication restrictions. We searched reference lists of articles from January 1984 to March week 12009 and proceedings of scientific meetings from January 1984 to April 2002. We also contacted investigators in the field. We evaluated other studies listed in previous meta-analyses. We did not make any formal enquiries through pharmaceutical companies. We stopped the search for conference proceedings after the early phase of this review in 2002 when we decided that in subsequent updates we will include new data only if reported in fully published papers.

\section{Data collection and analysis}

\section{Selection of studies}

Three review authors (LB, EP, SP) independently screened the titles and abstracts of all the references retrieved by the search strategy. The full text of relevant studies were assessed independently to determine whether they met the inclusion criteria. Disagreements were resolved by discussion with the two review authors (AL, RD).

\section{Data extraction and management}

Three review authors (LB, EP, SP) independently extracted data from all the included studies using an ad hoc extraction form. Disagreements were solved by discussion with two review authors (AL, RD).

\section{Assessment of risk of bias in included studies}

At least two review authors (LB, EP, SP) independently assessed the methodological validity of selected trials according to two quality criteria:

- quality of randomisation procedures ('adequate' versus 'unclear, inadequate or not done' which will be referred hereafter as 'not adequate'); and

- blinding of patients and doctors to allocated treatment ('doubleblind' versus 'open').

We resolved outstanding issues by consensus.

Only RCTs were accepted in order to prevent possible selection bias. Studies including adult patients admitted to an ICU were included. Studies based on specific pre-selected types of patients (that is, patients undergoing elective oesophageal resection, cardiac or gastric surgery, liver transplant or suffering from acute liver failure) were excluded.

\section{Measures of treatment effect}

Crude proportions of RTIs and mortality were our main treatment end-points. Odds ratios (OR) for each trial and for each outcome were calculated and they were summarised by using the fixedeffect model, whereas the random-effects model was used in cases of statistically significant heterogeneity $(P=0.1)$. We also computed the number of ICU patients who need to be treated in order to prevent one infection and one death. The calculation was based on the median rates of RTIs and deaths in untreated controls and the common OR for all trials.

\section{Dealing with missing data}

We contacted study investigators in order to obtain data for intention-to-treat analysis. In 25 out of 36 studies we obtained data on patients lost to follow-up while for the remaining 11 studies we relied on published information only.

\section{Data synthesis}

Results from the trials were combined using a fixed-effect model to calculate odds ratio (OR) with $95 \%$ confidence intervals $(\mathrm{Cl})$ for 
dichotomous data. In case of statistically significant heterogeneity a random-effects model was used.

The number needed to treat to benefit (NNTB) was calculated.

\section{Subgroup analysis and investigation of heterogeneity}

Two pre-specified subgroup analyses based on quality criteria were carried out within the two main groups of RCTs specified above:

- quality of randomisation procedures; and

- blinding of patients and doctors to allocated treatment.

\section{RE S U L T S}

\section{Description of studies}

\section{Results of the search}

Sixty potentially eligible RCTs were identified from the electronic searches.

\section{Included studies}

Thirty-six RCTs were finally included, all of them were published (34 as full reports and two in abstract form). Seventeen RCTs compared topical and systemic antibiotic treatment versus no treatment or placebo; 14 RCTs compared topical treatment to no treatment or placebo; and five trials compared topical and systemic antibiotic treatment versus systemic antibiotic only.

We included two studies (Gaussorgues 1991; Laggner 1994) among the 'topical SDD plus systemic antibiotic versus systemic antibiotic only' group even if their design did not explicitly foresee the use of systemic antibiotics because all patients in both arms were treated with systemic antibiotics on admission. Similarly, we included the Jacobs (Jacobs 1992) study among the 'topical SDD plus systemic antibiotics versus control' group because more than $90 \%$ of patients received a systemic antibiotic on admission.

The four studies with a three-arm comparison were analysed as follows. In two studies (Aerdts 1991; Verwaest 1997) the two control groups were pooled together and compared to the treatment group. In another study (Lingnau 1997) we split the study into two comparisons in which two different treatment arms were compared to the same control arm. In one study (Palomar 1997) one of the two control arms was excluded because patients received only sucralfate. Another study (Camus 2005) was a four-arm factorial design in which we considered only two arms comparing antibiotic prophylaxis versus placebo.

Overall, the total number of patients randomised to either antibiotic prophylaxis versus placebo or no treatment was 6914 . The final meta-analysis was based upon 36 trials with 37 comparisons.

Two studies (Cerra 1992; Gaussorgues 1991) could not contribute to the RTIs analysis as they reported the number of episodes of RTIs and not the number of infected patients. Moreover, one trial (de Jonge 2003) did not assess RTIs as an endpoint.

Mortality was evaluated in ICU in 24 trials; hospital mortality was available only for six RCTs; two trials reported mortality in both ICU and hospital (de Jonge 2003; Georges 1994) and the exact time of assessment of mortality was not determined in four trials (Cerra 1992; Jacobs 1992; Kerver 1988; Pneumatikos 2002).

Most RCTs included general ICU patients. A few trials included mostly trauma (Boland 1991; Georges 1994; Lingnau 1997; Pneumatikos 2002; Quinio 1995; Stoutenbeek 1996; Stoutenbeek 2007) or surgical patients (Cerra 1992; Krueger 2002).

One-hundred percent of patients were mechanically ventilated in 26 studies; this percentage was lower in six trials (Brun-Buisson 1989; Blair 1991; Cockerill 1992; de Jonge 2003; Ulrich 1989; Winter 1992) and unknown in four (Camus 2005; Cerra 1992; Finch 1991; Krueger 2002). In Brun-Buisson's study (Brun-Buisson 1989) the percentage of ventilated patients was very low $(59 \%)$ probably because the setting of the study included both 'acute' and 'intermediate' areas of a medical ICU.

The percentage of immunocompromised patients was usually lower than 10\%; it was higher only in four trials (Brun-Buisson 1989; Finch 1991; Gastinne 1992; Laggner 1994). Sucralfate was routinely used in all patients for stress ulcer prophylaxis in nine trials (AbeleHorn 1997; Bergmans 2001; Ferrer 1994; Gaussorgues 1991; Jacobs 1992; Krueger 2002; Laggner 1994; Quinio 1995; Verwaest 1997). In many RCTs only RTIs acquired in ICU (that is, diagnosed after 48 hours from admission) were considered. Data on primary and acquired infections were considered together only in three trials (Boland 1991; Stoutenbeek 1996; Stoutenbeek 2007). Most studies (26 RCTs) evaluated only the occurrence of pneumonia, while seven RCTs also evaluated tracheobronchitis; information was lacking in three RCTs. Diagnostic criteria differed across trials. Few trial authors provided quantitative details on the cut-off point used as positive bacteriological confirmation.

\section{Excluded studies}

Twenty-six trials were excluded (see 'Charateristics of excluded studies' table) (Arnow 1996; Barret 2001; Bion 1994; Bouter 2002; de la Cal 2005; de Smet 2009; Flaherty 1990; Garbino 2002; Hellinger 2002; Hunefeld 1989; Jacobs 1995; Lipman 1994; Luiten 1995; Martinez 1994; Martinez-Pellus 1993; Nardi 2001; Rayes 2002; Rolando 1996; Ruza 1998; Lenhart 1994; Stoutenbeek 2; Schardey 1997; Smith 1993; Tetteroo 1990; Zobel 1991; Zwaveling 2002).

\section{Risk of bias in included studies}

Study quality was assessed looking at two criteria. These two quality criteria were used to perform one-way subgroup analyses for two treatment comparisons (topical plus systemic versus no treatment and topical alone versus no treatment) on the two main outcomes (RTIs and overall mortality).

\section{Allocation}

$\mathrm{A}=$ adequate; $\mathrm{B}=$ unclear $\mathrm{C}=$ inadequate; $\mathrm{D}=$ not used. Allocation concealment was evaluated according to the criteria in the Cochrane Handbook for Systematic Reviews of Interventions (Higgins 2008).

\section{Blinding}

Double-blind, open. 


\section{Effects of interventions}

\section{RTIs}

Results from 33 RCTs including 5697 patients were available for the analysis on the effects of different types of antibiotic prophylaxis on RTIs. The frequency of RTIs was 19\% among treated patients and $40 \%$ among controls in RCTs using a combination of topical plus systemic antibiotic and $20 \%$ and $31 \%$, respectively, in RCTs testing the effectiveness of topical prophylaxis. Overall, the ORs were less than 1 in all but two trials (Lingnau 1997; Wiener 1995) and reached conventional statistical significance $(P<0.05)$ in $22 / 34$ comparisons.

Since statistically significant heterogeneity was observed, a random-effects model was used to summarise study results. Results indicate a strong protective effect in RCTs where the combination of topical and systemic treatment (OR $0.28,95 \% \mathrm{Cl}$ 0.20 to 0.38 ) was tested. A significant protection emerged when topical prophylaxis was considered (OR $0.44,95 \% \mathrm{Cl} 0.31$ to 0.63 ). The effect was stronger in RCTs where topical antimicrobials were tested against no prophylaxis (OR $0.34,95 \% \mathrm{Cl} 0.21$ to 0.55 ). Less extreme results were observed in trials testing the combination of topical and systemic antibiotic against systemic prophylaxis (OR $0.79,95 \% \mathrm{Cl} 0.56$ to 1.13$)$.

These results indicate that four $(95 \% \mathrm{Cl} 3$ to 5$)$ or seven $(95 \% \mathrm{Cl} 6$ to 12 ) patients need to be treated to prevent at least one infection, depending on whether a combination of topical and systemic treatment or topical antimicrobials alone were tested (assuming, as baseline risk, the median values of $46 \%$ and $27 \%$, respectively, among control patients).

Regarding the pre-defined subgroup analyses, a statistically significant difference in the estimates of treatment effect was only found for quality of allocation concealment in the topical versus control comparison.

\section{Mortality}

Overall, 36 RCTs including 6,914 patients were available for the mortality analysis. The mortality was $24 \%$ among treated patients and $30 \%$ among controls on RCTs using a combination of topical plus systemic antibiotic; while it was $26 \%$ and $25 \%$ respectively in RCTs testing the effectiveness of topical SDD. The ORs were less than 1 in 26/38 comparisons but reached conventional statistical significance in three RCTs (de Jonge 2003; Krueger 2002; Stoutenbeek 1996); no trial showed a significant harmful effect of antibiotic prophylaxis.

Regarding mortality no statistically significant heterogeneity was observed among study results.

Results indicated a statistically significant reduction in mortality attributable to the use of a combination of topical and systemic treatment (OR $0.75,95 \% \mathrm{Cl} 0.65$ to 0.87 ). This suggests that 18 patients ( $95 \% \mathrm{Cl} 12$ to 36 ) (assuming a baseline risk of $29 \%$, median among control patients) need to be treated to prevent one death. On the other hand, no treatment effect emerged when RCTs testing topical antimicrobials were analysed (OR $0.97 ; 95 \% \mathrm{Cl} 0.82$ to 1.16 ).

The subgroup analyses produced the following results:

\section{Topical versus control}

Allocation concealment: adequate (OR $0.64,95 \% \mathrm{Cl} 0.27$ to 1.52$)$, not adequate (OR $0.99,95 \% \mathrm{Cl} 0.83$ to 1.18 ).

Blind design: double blind ( $\mathrm{OR} 0.99,95 \% \mathrm{Cl} 0.83$ to 1.20 ), open (OR $0.88,95 \% \mathrm{Cl} 0.56$ to 1.37$)$.

\section{Topical plus systemic versus no prophylaxis}

Allocation concealment: adequate (OR $0.77,95 \% \mathrm{Cl} 0.66$ to 0.90$)$, not adequate (OR $0.67,95 \% \mathrm{Cl} 0.48$ to 0.93 ).

Blind design: double blind (OR $0.63,95 \% \mathrm{Cl} 0.48$ to 0.83 ), open (OR $0.80,95 \% \mathrm{Cl} 0.68$ to 0.95$)$.

\section{ISCUSSION}

Since antibiotic prophylaxis based on SDD was introduced as a preventative measure against infection in critically ill patients, it has remained a controversial intervention (Stoutenbeek 1994). Due to the lack of a standard protocol and insufficient patient numbers, it has proved difficult to derive meaningful conclusions from individual clinical trials. Following initial enthusiasm from results of early uncontrolled studies and RCTs, antibiotic prophylaxis is not widely used as a routine treatment in ICUs. Concerns about the risk of antimicrobial resistance and increased costs are often quoted as important factors preventing its widespread adoption. A conservative attitude in introducing a new treatment into practice is understandable as long as doubts about its efficacy exist. Studies on prevention of VAP in ICU patients are complex, as patients are heterogeneous, diagnosis of pneumonia is controversial and outcomes depend upon a variety of factors. Despite the fact that antibiotic prophylaxis reduces the emergence of RTIs with remarkable consistency across individual trials, the effect on mortality was individually statistically significant in only three trials. An historical examination of review articles and editorials in this area indicates that for many years it was not fully realised that this could have been due to the small sample sizes of individual studies.

The meta-analysis reported here combines data across several studies in order to estimate treatment effects with more precision than is possible in a single study. The main limitation of this type of pooled analysis is that the patient population, the antibiotic regimen and the outcome definitions are not the same across studies. Nonetheless, we believe that it provides the best global picture of the effectiveness of the intervention despite some recent criticisms on the quality of primary studies and their combination (van Nieuwenhove 2001) which we feel we have convincingly addressed (Liberati 2001). Compared to the other six published meta-analyses (Heyland 1994; Hurley 1995; Kollef 1994; Nathens 1999; SDD Group 1993; Vanderbrouk-Gra 1991) we decided in our previously published review (D'Amico 1998) to analyse separately trials testing a combination of systemic and topical antibiotics and those testing topical antimicrobials. Though there is no consensus on the best way to classify antibiotic prophylaxis regimens, eventually it seemed more appropriate to consider the two groups of trials as two distinct approaches to antibiotic prophylaxis. This decision was made a priori, independently of knowing their results.

As already shown in our previous review (D'Amico 1998) and confirmed in this update, both types of prophylaxis have a strong protective effect on RTIs - with the effect being more marked when patients are treated with a protocol using topical plus systemic antibiotics. This effect looks consistent in all subgroup 
analyses, regardless of study design (adequate / not adequate allocation concealment, double-blind / open design). Overall, these results appear convincing even though it is acknowledged that no diagnostic test or procedure is ideal to diagnose RTIs in ICU patients.

More importantly, this updated review confirms that the use of a combination of topical and systemic antibiotics reduces overall mortality significantly. This treatment effect looks important from a clinical and public health point of view (in terms of the therapeutic implications for the care of ventilated patients in ICUs) and is also relevant from the scientific standpoint, as it suggests the future directions that research in this field should take.
Publication bias is unlikely to have influenced our results because we made a thorough effort to trace unpublished studies and because the vast majority of trials did not show statistically significant reduction in mortality on their own. Moreover, inspection of the relevant funnel plot for overall mortality reduction in patients receiving the combined treatment (see additional analysis, Figure 1) does not provide evidence of publication bias. Finally, if one ranks studies by their size, larger ones are those showing a statistically significant treatment effect on their own.

\section{Figure 1.}

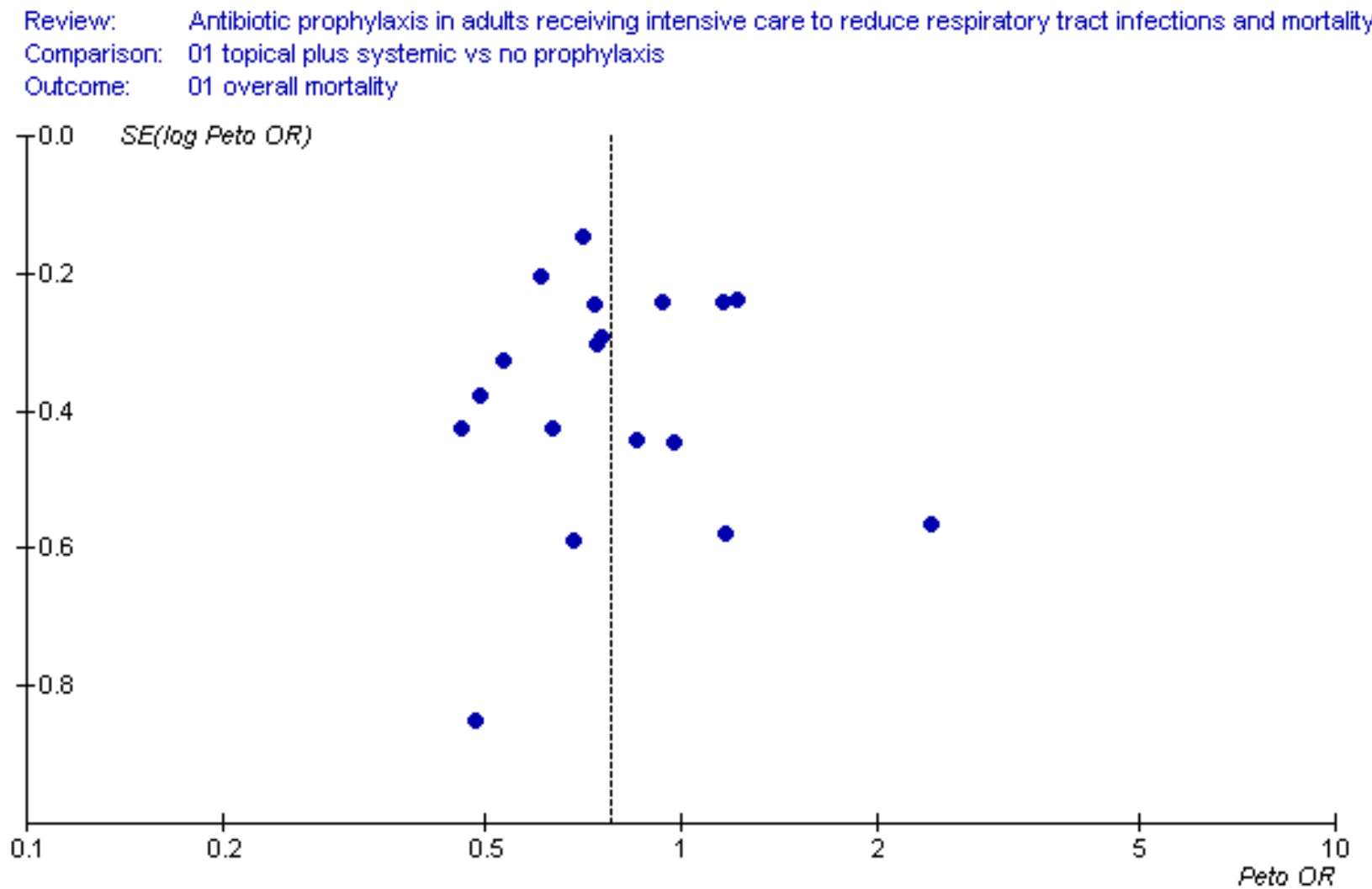

\section{AUTHORS' CONCLUSIONS}

\section{Implications for practice}

This systematic review indicates that a protocol testing a combination of topical and systemic antibiotics reduces the occurrence of RTIs and overall mortality. These results were initially obtained in an individual patient meta-analysis reported elsewhere (D'Amico 1998), which we have now updated using data reported in trials published between 1999 and 2007. The yield of the treatment expressed in terms of patients needed to be treated to prevent one infection and one death is substantial - 4 and 18 respectively - and compares very favourably with several interventions largely used in clinical practice. Though 11/17 trials used an identical regimen, including polymyxin, tobramycin and amphotericin as the topical combination and cefotaxime as the systemic component (Abele-
Horn 1997; Blair 1991; de Jonge 2003; Ferrer 1994; Hammond 1992; Jacobs 1992; Kerver 1988; Palomar 1997; Rocha 1992; Stoutenbeek 1996; Stoutenbeek 2007), this review does not allow a unique regimen to be recommended. The use of a prophylaxis testing topical antimicrobials is, on the other hand, not warranted by available data.

Results of this review should be carefully considered by those who have been sceptical about the effectiveness of antibiotic prophylaxis, mostly on the grounds of a potentially harmful effect in terms of antibiotic resistance (Collard 2003). Moreover, important new information has become available in a large randomised trial (de Jonge 2003) that was the first to be formally designed to reliably assess the occurrence of antibiotic resistance by randomising ICUs rather than patients and monitoring the units for more than 
two years after the inception of treatment use: de Jonge et al reported that no patients were colonised with meticillin-resistant staphylococcus aureus, only $1 \%$ was colonised with vancomicinresistant enterococcus and in 16\% and 26\% (in SDD and control patients, respectively) colonisation with gram negative bacteria resistant to ceftazidime, ciprofloxacin, imipenem, polymyxin E and tobramycin occurred (de Jonge 2003).

We believe that insufficient data on cost-effectiveness and antibiotic resistance should stimulate future research rather than preventing the adoption of a seemingly effective intervention. The impact of antibiotic prophylaxis on costs has so far been evaluated only rarely and, more importantly, in an improper way (the analysis being essentially based on comparisons of lengths of stay and computation of charges due to antibiotic use). A proper economic analysis is, on the other hand, likely to be difficult in a highly specialised setting such as an ICU, given that it is hard to quantify the relative contribution of single procedures.

\section{Implications for research}

The number of RCTs so far conducted on antibiotic prophylaxis is substantial and provides sufficient statistical power to detect a moderate but humanly worthwhile effect of the treatment on mortality. According to this systematic review, the combination of topical and systemic antibiotics should be the standard against which new treatments should be tested. A logical next step for future trials would be the comparison of this protocol against a regimen based on a systemic antimicrobial only; only six trials included in this review chose this as their study design. However, it is unlikely that one or more even large conventional trial can satisfy the concerns of those who are afraid that antimicrobial resistance may occur as a consequence of widespread use of antibiotics. However, the trial by de Jonge (de Jonge 2003) has shown that trials with innovative designs are possible and that they allow for a more reliable assessment of the occurrence of antibiotic resistance.

At the current stage of development of this intervention there does not seem to be a commercial interest by pharmaceutical companies to support further trials. Similarly, the intensivists' community seems rather sceptical about the merits of the intervention and it is not willing to embark on new, properly designed and conducted studies.

A systematic analysis of the quality and reliability of existing data on resistance might, in this sense, be important to get a more comprehensive view of the yield of the treatment. Such a review should be carried out even though it is highly likely that the necessary harms data are not available in published trials.

\section{A C K N OWLEDGEMENTS}

This systematic review would have not been possible without the continuous and enthusiastic support of most of the trials investigators. They collaborated in the different phases of this review up to the publication of our earlier review (D'Amico 1998) by providing information on the design and conduct of their studies, checking the accuracy of the data before the final analysis, attending a meeting where preliminary results were presented and, finally, reviewing earlier drafts of the manuscript. They are listed below:
M Abele-Horn 1997 (Ludwig-Maximilians-Universitat, Munich, Germany); SJA Aerdts 1991 (Sophia Hospital, Zwolle, The Netherlands); P Blair 1991, B J Rowlands, H Webb and K Lowry (Royal Victoria Hospital, Belfast, Northern Ireland); JP Boland 1991, D Sadler, A Stewart and J Pollock (Health Science Center Charlestone, West Virginia University, West Virginia, USA); C Brun-Buisson 1989 (Hopital Henry Mondor, Creteil, France); FB Cerra 1992 (University of Minnesota Hospital and Clinic, Minneapolis, USA); FR Cockerill 1992 and RL Thompson (Mayo Clinic, Rochester, Minnesota, USA); M Ferrer 1992 and A Torres (Servei de Pneumologia, Hospital Clinic, Barcelona, Spain); RG Finch 1991, P Tomlinson and G Rocker (Nottingham City Hospital, Nottingham, United Kingdom); H Gastinne 1992 (on behalf of the French study group on Selective Decontamination of the Digestive Tract - France); P Gaussorgues 1991 (Hopital Eduoard Herriot, Lyon, France); B Georges 1994 (Hopital de Rangueil, Toulouse, France); JMJ Hammond 1992, PD Potgieter (Groote Schuur Hospital, Cape Town, South Africa); S Jacobs (University Hospital of Wales, Cardiff, United Kingdom); S Jacobs and M Zuleika (Riyadh Armed Forces Hospital, Riyadh, Saudi Arabia); AJH Kerver 1988 (Sint Franciskus Hospital, Rotterdam, Utrecht, The Netherlands); AM Korinek 1993 (Hopital Pitie-Salpetriere, Paris, France); AN Laggner 1994 (Vienna General Hospital, Vienna, Austria); FP Lenhart 1994 (University of Munich, Germany); W Lingnau (Leopold-FranzensUniversitat Innsbruck, Innsbruck, Austria); A Martinez-Pellus and J Rodriguez-Rolda 1990 (University Hospital Virgen de la Arrixaca, El Palmar, Murcia, Spain); M Palomar 1997 (Hospital Vall d'Hebron, Barcelona, Spain); J Pugin 1991 and P Suter (University Hospital, Geneva, Switzerland); C Martin, B Quinio 1995 and J Albanese (Hopital Nord, Marseilles, France); LA Rocha 1992 (Hospital Juan Canalejo, La Coruna, Spain); M Sanchez-Garcia 1992 (Hospital PPE Asturias, Alcala de Henares, Spain); CP Stoutenbeek 1994 (Academisch Ziekenhuis, Universiteit van Amsterdam, Amsterdam, The Netherlands); C Ulrich 1989 and J E Harinck-De Weerd (Westeinde Hospital, The Hague, The Netherlands); K Unertl 1987 (Klinikum Grosshadern, Munich, Germany); J Verhaegen and C Verwaest (University Hospital Gasthuisberg, Leuven, Belgium); J Wiener 1995 (Michael Reese Hospital, Chicago, USA); R Winter 1992 (Queens Medical Centre University Hospital, Nottingham, United Kingdom).

This review was originally initiated at the request of the French Society of Intensive Care in preparation for the consensus conference on Selective Decontamination of the Digestive Tract (Paris, December 1991) and led to the first publication in 1993 (SDD Group 1993). It was then continued and updated between 1993 and 1998 through resources made available from the Mario Negri Institute, Milan, Italy and an unrestricted grant provided by Hoechst Marion Roussel Italy, the sponsors had no control on the protocol preparation, data analysis and manuscript review and their support was sought after the decision of undertaking the review by the review authors. Since 2004 the review has been updated without any specific research grant attached using institutional resources of the review authors.

Finally, the review authors wish to thank the following referees for commenting on the 2009 updated review: Janet Wale, Tim Kenealy, Max Bulsara, and Jenny Doust. 


\section{R E F E R E N C E S}

\section{References to studies included in this review}

Abele-Horn 1997 \{published data only\}

Abele-Horn M, Dauber A, Bauernfeind A, Russwurm W, Seyfarth-Metzger I, Gleich P, et al. Decrease in nosocomial pneumonia in ventilated patients by selective oropharyngeal decontamination (SOD). Intensive Care Medicine 1997;23(2):187-95

\section{Aerdts 1991 \{published and unpublished data\}}

Aerdts SJA, van Dalen R, Clasener HAL, Festen J, van Lier HJJ, Vollaard EJ. Antibiotic prophylaxis of respiratory tract infection in mechanically ventilated patients. Chest 1991;100(3):783-91.

\section{Bergmans 2001 \{published data only\}}

Bergmans DCJJ, Bonten MJM, Gailard CA, Paling JC, van der Geest S, van Tiel FH, et al. Prevention of ventilatorassociated pneumonia by oral decontamination: a prospective randomized, double blind, placebo controlled study. American Journal of Respiratory and Critical Care Medicine 2001;164(3):382-8

\section{Blair 1991 \{published and unpublished data\}}

Blair P, Rowlands BJ, Lowry K, Webb H, Amstrong P, Smilie J. Selective decontamination of the digestive tract: a stratified, randomized, prospective study in a mixed intensive care unit. Surgery 1991;110(2):303-10.

Boland 1991 \{published and unpublished data\}

Boland JP, Sadler DL, Stewart W, Wood DJ, Zerick W, Snodgrass KR. Reduction of nosocomial respiratory tract infections in the multiple trauma patients requiring mechanical ventilation by selective parenteral and enteral antisepsis regimen (SPEAR) in the intensive care. XVII Congress of Chemotherapy. 1991.

\section{Brun-Buisson 1989 \{published and unpublished data\}}

Brun-Buisson C, Legrand P, Rauss A, Richard C, Montravers F, Besbes M, et al. Intestinal decontamination for control of nosocomial multiresistant Gram-negative bacilli. Annals of Internal Medicine 1989;110(11):873-81.

\section{Camus 2005 \{published data only\}}

Camus C, Bellissant E, Sebille W, Perrotin D, Garo B, Legras A, et al. Prevention of acquired infections in intubated patients with combination of two decontaminations regimens. Critical Care Medicine 2005;33(2):307-14.

\section{Cerra 1992 \{published and unpublished data}

Cerra FB, Maddaus MA, Dunn DL, Wells CL, Konstantinides NN, Lehmann SL, et al. Selective gut decontamination reduces nosocomial infections and length of stay but not mortality or organ failure in surgical intensive care unit patients. Archives of Surgery 1992;127(2):163-9.

\section{Cockerill 1992 \{published and unpublished data\}}

Cockerill FR III, Muller SR, Anhalt JP, Marsh HM, Farnell MB, Mucha $\mathrm{P}$, et al. Prevention of infection in critically ill patients by selective decontamination of the digestive tract. Annals of Internal Medicine 1992;117(7):545-53.

\section{de Jonge 2003 \{published data only\}}

de Jonge E, Schultz JM, Spanjaard L, Bossuyt PMM, Vroom MB Dankert J, et al. Effects of selective decontamination of digestive tract on mortality and acquisition of resistant bacteria in intensive care: a randomised controlled trial. Lancet 2003;362(9389):1011-6.

\section{Ferrer 1994 \{published and unpublished data\}}

Ferrer M, Torres A, Gonzàles J, de la Bellacasa JP, El-Ebiary M, Roca M, et al. Utility of selective digestive decontamination in mechanically ventilated patients. Annals of Internal Medicine 1994;120:389-95.

Finch 1991 \{published and unpublished data\}

Finch RG, Tomlinson P, Holliday M, Sole K, Stack C, Rocker G. Selective decontamination of the digestive tract (SDD) in the prevention of secondary sepsis in a medical/surgical intensive care unit. XVII International Congress Chemotherapy. 1991.

Gastinne 1992 \{published and unpublished data\} Gastinne H, Wolff M, Delatour F, Faurisson F, Chevret S. A controlled trial in intensive care units of selective decontamination of the digestive tract with nonabsorbable antibiotics. New England Journal of Medicine 1992;326:594-9.

\section{Gaussorgues 1991 \{published and unpublished data\}}

Gaussorgues P, Salord F, Sirodot M, Tigaud S, Cagnin S, Gerard M, et al. [Efficacité de la décontamination digestive sur la survenue des bactériémies nosocomiales chez les patients sous ventilation mécanique et recevant des betamimétiques]. Reanimation, Soins Intensifs, Medicine d'Urgence 1991;7:169-74.

Georges 1994 \{published data only\}

Georges B, Mazerolles M, Decun JF, Rouge P, Pomies S, Cougot P, et al. [Décontamination digestive sélective résultats d'une ètude chez le polytraumatisé]. Reanimation d'Urgence 1994;3:621-7.

Hammond 1992 \{published and unpublished data\}

Hammond JMJ, Potgieter PD, Saunders GL, Forder AA. Double blind study of selective decontamination of the digestive tract in intensive care. Lancet 1992;340:5-9.

Jacobs 1992 \{published and unpublished data\}

* Jacobs S, Foweraker JE, Roberts SE. Effectiveness of selective decontamination of the digestive tract (SDD) in an ICU with a policy encouraging a low gastric $\mathrm{pH}$. Clinical Intensive Care 1992;3:52-8.

Kerver 1988 \{published and unpublished data\}

Kerver AJH, Rommes JH, Mevissen-Verhage EAE, Hulstaert PF, Vos A, Verhoef $\mathrm{J}$, et al. Prevention of colonization and infection in critically ill patients: A prospective randomized study. Critical Care Medicine 1988;16:1087. 
Korinek 1993 \{published and unpublished data\}

Korinek AM, Laisne MJ, Raskine L, Deroin V, SansonLepors MJ. Selective decontamination of the digestive tract in neurosurgical care units patients: a double blind, randomized, placebo-controlled study. Critical Care Medicine 1993;21:1466-73.

\section{Krueger 2002 \{published data only\}}

Krueger WA, Lenhart FP, Neeser G, Ruckdeschel G, Schreckhase H, Eissner HJ, et al. Influence of combined intravenous and topical antibiotic prophylaxis on the incidence of infections, organ dysfunctions and mortality in critically ill surgical patients. American Journal of Respiratory and Critical Care Medicine 2002;166:1029-37.

\section{Laggner 1994 \{published and unpublished data\}}

Laggner AN, Tryba M, Georgopoulos A, Lenz K, Grimm G, Graninger W, et al. Oropharyngeal decontamination with gentamicin for long-term ventilated patients on stress ulcer prophylaxis with sucralfate?. Wiener Klinische Wochenschrift 1994;106:15-9.

\section{Lingnau 1997 \{published and unpublished data\}}

Lingnau W, Berger J, Javorsky F, Lejeune P, Mutz N, Benzer H. Selective intestinal decontamination in multiple trauma patients: prospective, controlled trials. Journal of Trauma 1997;42:687-94.

\section{Lingnau 1997b \{published and unpublished data\}}

Lingnau W, Berger J, Javorsky F, Lejeune P, Mutz N, Benzer H. Selective intestinal decontamination in multiple trauma patients: prospective, controlled trials. Journal of Trauma 1997;42:687-94.

\section{Palomar 1997 \{published and unpublished data\}}

* Palomar M, Alvarez-Lerma F, Jorda R, Bermejo B. Prevention of nosocomial infection in mechanically ventilated patients: Selective digestive decontamination versus sucralfate. Clinical Intensive Care 1997;8:228-35.

\section{Pneumatikos 2002 \{published data only\}}

Pneumatikos I, Koulouras V, Nathanail C, Goe D, Nakos G. Selective decontamination of subgloottic area in mechanically ventilated patients with multiple trauma. Intensive Care Medicine 2002;28:432-7.

\section{Pugin 1991 \{published and unpublished data\}}

Pugin J, Auckenthaler R, Lew DP, Suter PM. Oropharyngeal decontamination decreases incidence of ventilator-associated pneumonia. JAMA 1991;265:2704-10.

\section{Quinio 1995 \{published and unpublished data\}}

Quinio B, Albanèse J, Bues-Charbit M, Viviand X, Martin C. Selective Decontamination of the digestive tract in multiple trauma patients: prospective, double blind, randomised, placebo-controlled study. Chest 1996;109:765-72.

\section{Rocha 1992 \{published and unpublished data\}}

Rocha LA, Martin MJ, Pita S, Paz J, Seco C, Margusino L, et al. Prevention of nosocomial infection in critically ill patients by selective decontamination of digestive tract. Intensive Care Medicine 1992;18:398-404.

Rodriguez-Rolda 1990 \{published and unpublished data\}

Rodrìguez-Roldàn JM, Altuna-Cuesta $\mathrm{A}$, Lòpez $\mathrm{A}$, Carrillo $\mathrm{A}$, Garcia J, Leòn J, et al. Prevention of nosocomial lung infection in ventilated patients:use of an antimicrobial pharyngeal nonabsorbable paste. Critical Care Medicine 1990;18:1239-42.

\section{Sanchez-Garcia 1992 \{published and unpublished data\}}

Sanchez-Garcia M, Cambronero JA, Lopez J, Cerda E, Rubio J, et al. Effectiveness and cost of selective decontamination of the digestive tract (SDD) in critically ill intubated patients. A randomized, double blind, placebo-controlled, multicentric trial. American Journal of Respiratory and Critical Care Medicine 1998;158:908-16.

\section{Stoutenbeek 1996 \{published data only\}}

Stoutenbeek CP, Van Saene HKF, Miranda D R, Zandstra DF. The effect of selective decontamination of the digestive tract on colonization and infection rate in multiple trauma patients. Intensive Care Medicine 1984;10:185-92.

\section{Stoutenbeek 2007 \{published data only\}}

Stoutenbeek CP, Van Saene HKF, Little RA, Whitehead A. The effect of selective decontamination on the digestive tract on mortality in multiple trauma patients: a multicentre randomized controlled trial. Intensive Care Medicine 2007;33:261-70.

\section{Ulrich 1989 \{published and unpublished data\}}

Ulrich C, Harinck-deWeerd JE, Bakker NC, Jacz K, Doornbos L, de Ridder VA. Selective decontamination of the digestive tract with norfloxacin in the prevention of ICU-acquired infections: a prospective randomized study. Intensive Care Medicine 1989;15:424-31.

\section{Unertl 1987 \{published and unpublished data\}}

Unertl K, Ruckdeschel G, Selbmann HK, Jensen U, Forst H, Lenhart FP, et al. Prevention of colonization and respiratory infections in long term ventilated patients by local antimicrobial prophylaxis. Intensive Care Medicine 1987;13:106-13.

\section{Verwaest 1997 \{published and unpublished data\}}

Verwaest C, Verhaegen J, Ferdinande P, Schets M, Van der Berghe G, Verbist L, et al. Randomized, controlled trial of selective digestive decontamination in 600 mechanically ventilated patients in a multidisciplinary intensive care unit. Critical Care Medicine 1997;25:63-71.

\section{Wiener 1995 \{published data only\}}

Wiener J, Itokazu G, Nothan C, Kabins SA, Weinstein RA. A randomized, double-blind, placebo-controlled trial of selective digestive decontamination in a medical-surgical intensive care unit. Clinical Infectious Diseases 1995;20:861-7.

\section{Winter 1992 \{published and unpublished data\}}

Winter R, Humphreys H, Pick A, MacGowan AP, Willatts SM, Speller DCE. A controlled trials of selective decontamination of the digestive tract in intensive care and its effect on nosocomial infection. Journal of Antimicrobial Chemotherapy 1992;30:73-87. 


\section{References to studies excluded from this review}

\section{Arnow 1996 \{published data only\}}

Arnow PM, Carandanq GC, Irwin ME. Randomized controlled trial of selective bowel decontamination for prevention of infections following liver transplantation. Clinical Infectious Diseases 1996;22:997-1003.

\section{Barret 2001 \{published data only\}}

Barret JP, Jeschke MG, Herndon DN. Selective decontamination of the digestive tract in severely burned pediatric patients. Burns 2001;27:439-45.

\section{Bion 1994 \{published data only\}}

Bion JF, Badger I, Crosby HA, Hutchings P, Kong KL, Baker J, et al. Selective decontamination of the digestive tract reduces Gram-negative pulmonary colonization but not systemic endotoxemia in patients undergoing elective liver transplantation. Critical Care Medicine 1994;22:40-9.

\section{Bouter 2002 \{published data only\}}

Bouter H, Schippers EF, Luelmo SAC, Verteegh MIM, et al. No effect of preoperative selective gut decontamination on endotoxemia and cytokine activation during cardiopulmonary bypass: A randomized, placebo controlled study. Critical Care Medicine 2002;30:38-43.

\section{de la Cal 2005 \{published data only\}}

de la Cal MA, Cerdà E, Garcia-Hierro P, et al. Survival benefit in critically hill burned patients receiving selective decontamination of the digestive tract. A randomized, placebocontrolled, double-blind trial. Annals of Internal Medicine 1992;117:545-53.

\section{de Smet 2009 \{published data only\}}

de Smet AMGA, Kluytmans JAJW, Cooper BS, Mascini EM, Benus RFJ, van der Werf TS, et al. Decontamination of the digestive tract and oropharynx in ICU patients. NEJM 2009;360:20-31.

\section{Flaherty 1990 \{published data only\}}

Flaherty J, Nathan C, Kabins SA, Weinstein RA. Pilot trial of selective decontamination for prevention of bacterial infection in an intensive care unit. Journal of Infectious Diseases 1990;162:1393-7.

\section{Garbino 2002 \{published data only\}}

Garbino J, Lew DP, Romand JA, Hogonnet S, Auckenthaler R, Pittet D. Prevention of severe candida infections in nonneutropenic high risk, crically ill patients: a randomized, double blinded, placebo controlled trial in patients treated by severe digestive decontamination. Intensive Care Medicine 2002;28:1708-17.

\section{Hellinger 2002 \{published data only\}}

Hellinger WC, Yao JD, Alvarez S, Blair JE, et al. A randomized, prospective, double blinded evaluation of selective bowel decontamination in liver transplantation. Transplantation 2002;73:1904-9.
Hunefeld 1989 \{published and unpublished data\}

Hunefeldt G. [Klinische Studie zur selectiven Darmdekolonisation bei 204 langzeitbeatmeten abdominal und unfallchirurgischen Intensivpatienten]. Anaesthesiologie und Reanimation 1989;14:131-53.

Jacobs 1995 \{unpublished data only\} Jacobs S, Zuleika M. no title. provided by the authors.

Lenhart 1994 \{published data only\}

Lenhart FP, Unertl K, Neeser G, Ruckdeschel G, Eckart J, Peter K. Selective decontamination and sucralfate for prevention of acquired infections in intensive care. 17th International Congress Chemotherapy, Vienna 1994 (K101). 1994.

\section{Lipman 1994 \{published and unpublished data\}}

Lipman J, Klugman K, Luyt D, Kraus P, Litmanovitch M, Johnson D, et al. Unique trial design shows SDD to decrease and alter colonization of upper respiractory tract in a multidisciplinary ICU. Critical Care Medicine 1994;22:1.

\section{Luiten 1995 \{published data only\}}

Luiten EJ, Hop WC, Lange JF, Bruining HA. Controlled clinical trial of selective decontamination for the treatment of severe acute pancreatitis. Annals of Surgery 1995;222:57-65.

\section{Martinez 1994 \{published data only\}}

* Martinez PAE, Bru M, Jara P, Ruiz J, Sanmiguel MT, Garcia PT. Does cefotaxime prevent early pneumonia in trauma patients receiving pharyngeal decontamination?. Medicina Intensiva 1994;18:245-9.

\section{Martinez-Pellus 1993 \{published data only\}}

Martinez-Pellus AE, Merino P, Bru M, Coneyero R, Seller G, Munoz $C$, et al. Can selective digestive decontamination avoid the endotoxemia and cytokine activation promoted by cardiopulmonary bypass?. Critical Care Medicine 1993;2:1684-91.

\section{Nardi 2001 \{published data only\}}

Nardi G, Di Silvestre A, De Monte A, Massarutti D, Proietti A, Grazia Troncon M, et al. Reduction in gram positive pneumonia and antibiotic consumption following the use of a SDD protocol including nasal nad oral mupirocin. European Journal of Emergency Medicine 2001;8:203-14.

\section{Rayes 2002 \{published data only\}}

Rayes N, Seehofer D, Hansen S, Boucsein K, et al. Early enteral supply of lactobacillus and fiber versus selective bowel decontamination: a controlled trial in liver transplant recipients. Transplatation 2002;74:123-8.

\section{Rolando 1996 \{published and unpublished data\}}

Rolando N, Wade J, Stangou A, Gimson AE, Wendon J, PhilpottHoward J, et al. Prospective study comparing the efficacy of prophylactic parenteral antimicrobials, with or without enteral decontamination, in patients with acute liver failure. Liver Transplantation and Surgery 1996;2:8-13. 
Ruza 1998 \{published data only\}

Ruza F, Alvarado F, Herruzo R, Delgado MA, García S, Dorao P, et al. Prevention of nosocomial infection in a pediatric intensive care unit (PICU) through the use of selective digestive decontamination. European Journal of Epidemiology 1998;14:719-27.

\section{Schardey 1997 \{published and unpublished data\}}

Schardey HM, Joosten U, Finke U, Stanbach KH, Schauer R, Heiss A, et al. The prevention of anastomotic leakage after total gastrectomy with local decontamination. A prospective doubleblind, randomized and placebo-controlled clinical multicenter trial. Annals of Surgery 1997;225:172-80.

\section{Smith 1993 \{published data only\}}

Smith SD, Jackson RJ, Hannakan CJ, Wadowsky RM, Tzakis AG, Rowe MI, et al. Selective decontamination in pediatric liver transplant. A randomized prospective study. Transplantation 1993;55:1306-9.

\section{Stoutenbeek 2 \{unpublished data only\}}

Stoutenbeek CP, Van Saene HKF, Little RA, Whitehead A. The effect of selective decontamination of the digestive tratct on mortality in multiple trauma patients.. Contact with authors.

\section{Tetteroo 1990 \{published and unpublished data\}}

Tetteroo GWM, Wagenvoort JHT, Castelei A, Tilanus HW, Ince C, Bruining HA. Selective decontamination to reduce gram-negative colonisation and infections after oesophageal resection. Lancet 1990;335:704-7.

\section{Zobel 1991 \{published data only\}}

Zobel G, Kutting M, Grubbauer HM, Semmelrock HJ, Thiel W. Reduction of colonization and infection rate during pediatric intensive care by selective decontamination of digestive tract. Critlical Care Medicine 1991;19:1242-6.

\section{Zwaveling 2002 \{published data only\}}

Zweveling JH, Maring JK, Klompmaker IJ, Haagsma EB Bottema JT, Laseur M, et al. Selective decontamination of the digestive tract to prevent postoperative infection: a randomized placebo-controlled trial in liver transplant patients. Critical Care Medicine 2002;30(6):1204-9.

\section{Additional references}

\section{Chevret 1996}

Chevret S, Hemmer M, Carlet J, Langer M. Incidence and risk factors of pneumonia acquired in intensive care units. Results from a multicenter prospective study on 996 patients. European Cooperative Group on Nosocomial Pneumonia. JAMA 1996;275(11):866-9.

\section{Collard 2003}

Collard HR, Saint S, Matthay MA. Prevention of ventilatorassociated pneumonia: an evidence-based systematic review. Annals of Internal Medicine 2003;138(6):494-501.

\section{Fagon 1996}

Fagon JY, Chastre J, Vuagnat A, Trouillet JL, Novara A, Gibert C. Nosocomial pneumonia and mortality among patients in Intensive care unit. JAMA 1996;275:866-9.

\section{Heyland 1994}

Heyland DK, Cook DJ, Jaescher R, Griffith L, Lee HN, Guyatt GH. Selective decontamination of the digestive tract. An overview. Chest 1994;105:1221-9.

\section{Higgins 2008}

Higgins JPT, Green S. Cochrane Handbook for Systematic Reviews of Interventions. Version 5.0.0. The Cochrane Collaboration, 2008

\section{Hurley 1995}

Hurley JC. Prophylaxis with enteral antibiotics in ventilated patients: selective decontamination or selective crossinfection?. Antimicrobial Agents and Chemotherapy 1995;39:941-7.

\section{Kollef 1994}

Kollef $\mathrm{MH}$. The role of selective digestive tract decontamination on mortality and respiratory tract infections. A meta-analysis. Chest 1994;105:1101-8.

\section{Lefebvre 2008}

Lefebvre C, Manheimer E, Glanville J. Chapter 6: Searching for studies. In: Higgins JP, Green S editor(s). Cochrane Handbook for Systematic Reviews of Interventions. Chichester, UK: Wiley, 2008.

\section{Liberati 2001}

Liberati A, D'Amico R, Brazzi L, Pifferi S. Influence of methodological quality on study conclusions. JAMA 2001;286:2544-5.

\section{Nathens 1999}

Nathens AB. Selective decontamination of digestive tract in surgical patients: a systematic review of evidence. Archives of Surgery 1999;134:170-6.

\section{Redman 2001}

Redman R, Ludington E. Analysis of respiratory and nonrespiratory infections in published trials of selective digestive decontamination. Intensive Care Medicine (14th Annual Congress of the European Society of Intensive Care Medicine 2001). 2001, issue Suppl 2:285.

\section{Silvestri 2007}

Silvestri L, van Saene HKF, et al. Selective decontamination of the digestive tract reduces bacterial bloodstreem infection and mortality in critically ill patients. Systematic review of randomized controlled trials. Journal of Hospital Infection 2007;65:187-203.

\section{Stoutenbeek 1994}

Stoutenbeek CP, Van Saene HKF, Miranda DR, Zandstra DF. The effect of selective decontamination of the digestive tract on colonization and infection rate in multiple trauma patients. Intensive Care Medicine 1994;10:185-92. 


\section{van Nieuwenhove 2001}

van Nieuwenhoven CA, Buskens E, van Tiel FH, Bonten MJ. Reletionship between methodological trial quality and the effects of selective digestive decontamination on pneumonia and mortality in critically ill patients. JAMA 2001;286:335-40.

\section{Vanderbrouk-Gra 1991}

Vanderbrouk-Grauls CM, Vanderbrouke-Grauls JP. Effect of selective decontamination of the digestive tract on respiratory tract infections and mortality in intensive care unit. Lancet 1991;338:859-62.

\section{References to other published versions of this review}

\section{D'Amico 1998}

D'Amico R, Pifferi S, Leonetti C, Torri V, Tinazzi A, Liberati A, et al. Effectiveness of antibiotic prophylaxis in critically ill adult patients: systematic review of randomised controlled trials. BMJ 1998;316:1275-85.

\section{Liberati 1997}

Liberati A, D'Amico R, Pifferi S, Leonetti C, Torri V, Brazzi L, et al. Antibiotic prophylaxis in adult patients treated in Intensive Care
Units. Cochrane Database of Systematic Reviews 1997, Issue 3. [DOI: 10.1002/14651858.CD000022.pub2]

\section{Liberati 2002}

Liberati A, D'Amico R, Pifferi S, Leonetti C, Torri V, Brazzi L, et al. Antibiotics for preventing respiratory tract infections in adults receiving intensive care. Cochrane Database of Systematic Reviews 2002, Issue 4. [DOI: 10.1002/14651858.CD000022.pub2]

\section{Liberati 2004}

Liberati A, D'Amico R, Pifferi, Torri V, Brazzi L. Antibiotic prophylaxis to reduce respiratory tract infections and mortality in adults receiving intensive care. Cochrane Database of Systematic Reviews 2004, Issue 1. [DOI: 10.1002/14651858.CD000022.pub2]

\section{SDD Group 1993}

SDD Trialists' Collaborative Group. Meta-analysis of randomised controlled trials of selective decontamination of the digestive tract. British Medical Journal 1993;307:525-32.

\section{* Indicates the major publication for the study}

\section{CHARACTERISTICS OF STUDIES}

Characteristics of included studies [ordered by study ID]

Abele-Horn 1997

$\begin{array}{ll}\text { Methods } & \text { Randomised controlled study } \\ \text { Blinding: Open } & \\ \text { Randomisation method: list block randomised assignments maintained by the main investigator } \\ \text { Accrual period: not available }\end{array}$

Participants

Eligibility criteria: intubation within $24 \mathrm{hrs}$ of admission, expected ventilation for at least four days, first microbial culture within 36 hrs of admission

Exclusion criteria: transfer from other hospitals, evidence of infection, prior antibiotic therapy, ARDS, leucopenia, myelosuppression

Patients enrolled in the study: $125 ; 37$ patients were excluded leaving 88 patients for analysis

Percentage of ventilated patients: $100 \%$

ICU length of stay, mean: 19.3 days

Type of admission diagnosis: surgical unscheduled $=16 \%$ trauma $=84 \%$

Severity score on admission: APACHE II mean $=17$, ISS not available

Percentage of immunocompromised patients:not available

Percentage of patients treated with systemic antibiotic therapy (not stated by protocol) in the first three days: not available Stress ulcer prophylaxis applied: sucralfate $1 \mathrm{~g} \times$ four to all patients

Interventions

Group A, Treatment:

- polymyxin $100 \mathrm{mg}$, tobramycin $80 \mathrm{mg}$, amphotericin B $500 \mathrm{mg}$ applied orally four times a day as a $2 \%$ paste during the ICU stay

- cefotaxime $2 \mathrm{~g} \times 3$ iv $\mathrm{x}$ three days

Group B, CTR:

- No prophylaxis

Antibiotic prophylaxis was performed only for abdominal, orthopedic and neurologic surgery 
Abele-Horn 1997 (Continued)

Diagnosis was based on Clinical Pulmonary Infection Score as defined by Pugin 1991: new pulmonary infiltrate on X-ray, increasing amount of tracheal secretions containing $>3 \times 10^{4}$ granulocytes $/ \mathrm{mcl}$ and at least two of the following: temperature $>38.5^{\circ} \mathrm{C}, \mathrm{WBC}>12,000 / \mathrm{mm}^{3}$ or $<4,000 / \mathrm{mm}^{3}$, decrease in $\mathrm{PaO}_{2}$ requiring an increase in $\mathrm{FiO}_{2}$. Besides a bacteriological confirmation is required: tracheal aspirates yielding bacteria $>10^{4} \mathrm{CFU} / \mathrm{ml}$ and granulocytes $>10 /$ field

Mortality: in ICU

Notes Data about 37 excluded patients are not available

\section{Risk of bias}

\begin{tabular}{lll}
\hline Bias & Authors' judgement & Support for judgement \\
\hline $\begin{array}{l}\text { Allocation concealment } \\
\text { (selection bias) }\end{array}$ & Unclear risk & B - Unclear \\
\hline
\end{tabular}

\section{Aerdts 1991}

$\begin{array}{ll}\text { Methods } & \text { Randomised study with three arms (one treatment arm versus two control arms) } \\ \text { Blinding: outcome assessor } \\ \text { Randomisation method: sealed envelopes, permuted block method. } \\ \text { Accrual period: May } 86 \text { to Sept } 87\end{array}$
Participants Eligibility criteria: expected ventilation for at least five days, inclusion within 24 hrs of admission Exclusion criteria: age $<16$ yrs, pregnancy, allergy to one of the component of the regimen
Patients enrolled in the study: 88
Percentage of ventilated patients: $100 \%$
ICU length of stay, median: 16 days
Type of admission diagnosis: medical $=40 \%$ surgical scheduled $=6 \%$ surgical unscheduled $=20 \%$ trau- $\mathrm{ma}=34 \%$
Severity score on admission: APACHE II mean $=21.8$, ISS not available
Percentage of immunocompromised patients: $4.6 \%$
Percentage of patients treated with systemic antibiotic therapy (not stated by protocol) in the first three days: Treatment $=35 \%$ CTR $=80 \%$
Stress ulcer prophylaxis applied: antiacids until enteral feeding was possible

$\begin{array}{ll}\text { Interventions } & \text { Group A, CTR 1: } \\ & \text { - No prophylaxis, infections of unknown origin were treated with ampicillin+gentamicin } \\ & \text { Group B, CTR 2: } \\ & \text { - No prophylaxis, infections of unknown origin were treated with cefotaxime+gentamicin and metron- } \\ & \text { idazole if indicated. } \\ & \text { Group C, Treatment: } \\ \text { - polymyxin E } 200 \mathrm{mg} \text {, norfloxacin } 50 \mathrm{mg} \text {, amphotericin B } 500 \mathrm{mg} \text { applied enterally four times a day } \\ \text { and, as a 2\% paste, to the oropharynx until extubation } \\ \text { - cefotaxime } 500 \mathrm{mg} \times 3 \text { iv x five days. Infections of unknown origin were treated as group B }\end{array}$

Outcomes

Respiratory infections (acquired pneumonia and tracheobronchitis):

Diagnosis of tracheobronchitis was based on: positive culture of the tracheal aspirate and a gram stain showing many leukocytes as well as the causative organism, associated with two of the following: temperature $>38^{\circ} \mathrm{C}, \mathrm{WBC}>12000 / \mathrm{mm}^{3}$, purulent tracheal aspirate Diagnosis of pneumonia was based on: a new and persistent pulmonary infiltrate on X-ray and criteria of tracheobronchitis

Mortality: in ICU 
Aerdts 1991 (Continued)

Personal contact with the main investigator provided data about 32 patients who were excluded from the published paper ( 16 early extubation, seven early deaths, five protocol violation, three other, one unknown); these data are considered in the analysis

\section{Risk of bias}

\begin{tabular}{lll}
\hline Bias & Authors' judgement & Support for judgement \\
\hline $\begin{array}{l}\text { Allocation concealment } \\
\text { (selection bias) }\end{array}$ & Low risk & A - Adequate \\
\hline
\end{tabular}

\section{Bergmans 2001}

$\begin{array}{ll}\text { Methods } & \text { Randomised, placebo-controlled study. } \\ \text { Blinding: double blind. }\end{array}$

Blinding: double blind.

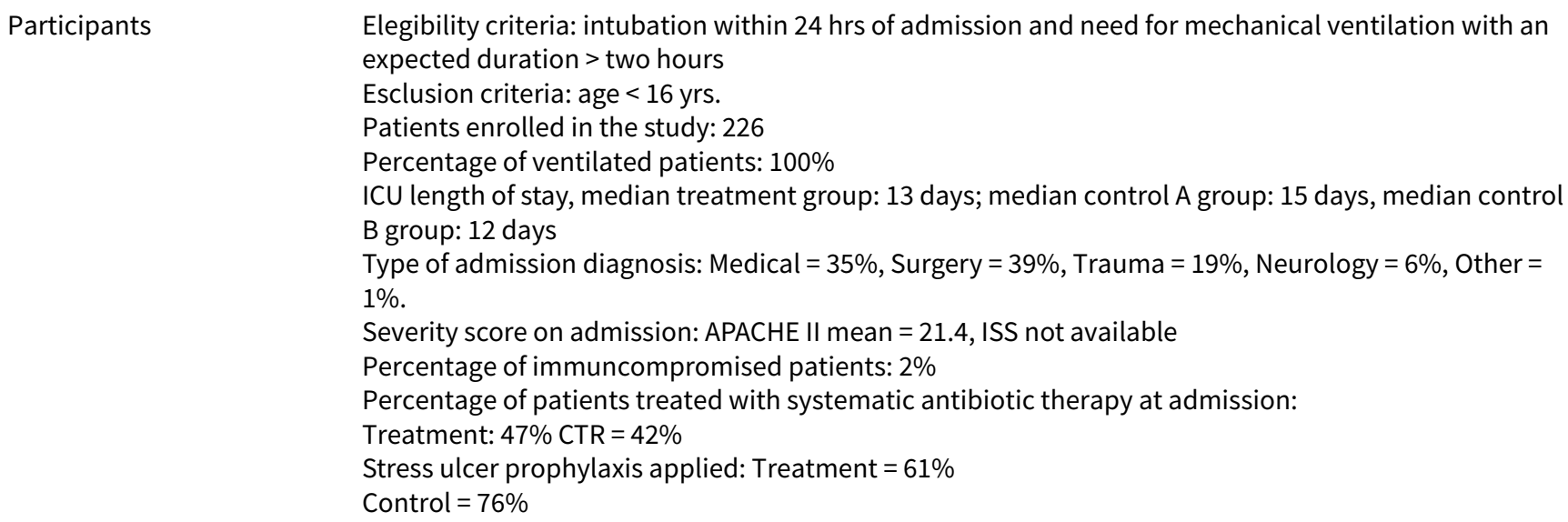
titative cultures from BAL (cutoff point $>=10^{4}$ colony-forming units $[\mathrm{cfu}] / \mathrm{ml}$ ) or PSB (cutoff point $>=10^{3}$ $\mathrm{cfu} / \mathrm{ml}$ ), or a positive blood culture unrelated to another source of infection, or a positive culture from pleural fluid in the absence of previous pleural instrumentation.

Mortality: in hospital 
Bergmans 2001 (Continued)

\begin{tabular}{lll} 
Bias & Authors' judgement & Support for judgement \\
\hline $\begin{array}{l}\text { Allocation concealment } \\
\text { (selection bias) }\end{array}$ & Unclear risk & B - Unclear \\
\hline
\end{tabular}

Blair 1991

$\begin{array}{ll}\text { Methods } & \text { Randomised study } \\ & \text { Blinding: Open. } \\ & \text { Randomisation method: sealed envelopes. } \\ & \text { Accrual period: Sept. } 1988 \text { to Jan } 1990\end{array}$

\section{Participants}

Eligibility criteria: all admitted patients who do not fulfil the exclusion criteria

Exclusion criteria: patients discharged within $48 \mathrm{hrs}$ of ICU admission; admission from CCU; patients expected to die after six hrs of ICU admission; patients with discharge anticipated within 48 hrs but remaining more than $48 \mathrm{hrs;}$ drug overdose; security patients; age $<18 \mathrm{yrs}$; patients not randomised within six hrs of admission; readmission to ICU; burns; miscellaneous

Patients enrolled in the study: 331

Percentage of ventilated patients: $93 \%$

Length of stay in ICU, median: five days

Type of admission diagnosis: medical $=14 \%$ surgical scheduled $=33 \%$ surgical unscheduled $=13 \%$ trauma $=40 \%$

Severity score on admission: APACHE II mean $=14.4$, ISS mean $=24.8$

Percentage of immunocompromised patients: $1.8 \%$

Percentage of patients treated with systemic antibiotic therapy (not stated in the protocol) in the first three days: treatment $=42 \%$ CTR $=74 \%$

Stress ulcer prophylaxis applied: all patients received ranitidine iv plus antiacid therapy if gastric $\mathrm{pH}$ was low

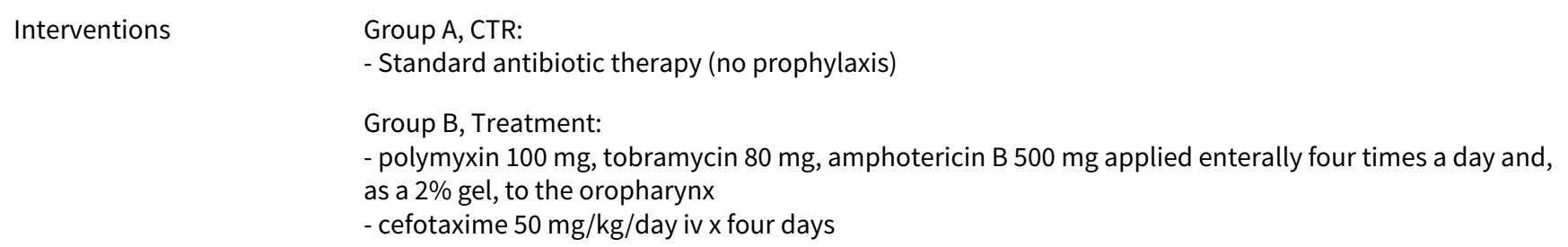

Outcomes Respiratory infections (pneumonia acquired after $48 \mathrm{hrs}$ ). Diagnosis of infection was based on the fulfilment of Criteria I or Criteria II.

Criteria I: temperature $>38.5^{\circ} \mathrm{C}$ on two separate occasion, WBC $>12 \times 10^{9} / \mathrm{l}$ or $<4 \times 10^{9}$ and a new pulmonary infiltrate on X-ray.

Criteria II: temperature $>37.5^{\circ} \mathrm{C}$, a new pulmonary infiltrates on $\mathrm{X}$-ray, purulent sputum and drop in $\mathrm{PaO}_{2}$

Mortality: in ICU

Notes Personal contact with the main investigator provided data about 75 patients who were excluded from the published paper for short length of stay; these data are considered in the analysis

\section{Risk of bias}

\begin{tabular}{lll}
\hline Bias & Authors' judgement & Support for judgement \\
\hline $\begin{array}{l}\text { Allocation concealment } \\
\text { (selection bias) }\end{array}$ & Low risk & A - Adequate \\
\hline
\end{tabular}


Boland 1991

$\begin{array}{ll}\text { Methods } & \text { Randomised, placebo-controlled study } \\ \text { Blinding: double blind } \\ \text { Randomisation method: computer generated randomisation directed by the pharmacy department } \\ \text { Accrual period: Apr } 89 \text { to Mar } 91\end{array}$

Eligibility criteria: all multiple traumatised patients, intubated at the time of admission and likely to
stay intubated at least five days
Exclusion criteria: patients who did not remain intubated for five days
Patients enrolled in the study: 64
Percentage of ventilated patients: $100 \%$
Length of stay in ICU, median: eight days
Type of admission diagnosis: trauma = 100\%
Severity score on admission: APACHE II mean $=16.8$, ISS not available
Percentage of immunocompromised patients: $0 \%$
Percentage of patients treated with systemic antibiotic therapy (not stated in the protocol) in the first
three days: treatment = $0 \%$ CTR $=0 \%$
Stress ulcer prophylaxis applied: H2-blockers or sucralfate (78\%)
Group A, CTR:
- Placebo
Group B, Treatment:
- polymyxin 100 mg, tobramycin 80 mg, nystatin $1,600,000$ units applied enterally four times a day and,
as a $2 \%$ paste plus 60,000 units of nystatin, to the oropharynx until extubation or discharge
- cefotaxime $1 \mathrm{~g} \times 3$ iv for the first three days

\begin{tabular}{ll} 
Outcomes & $\begin{array}{l}\text { Respiratory infections (acquired pneumonia and tracheobronchitis). } \\
\text { Diagnosis of infection was based on: } \\
\text { positive sputum culture for bacteria, fever }>38^{\circ} \mathrm{C} \text { and leukocytosis }\left(>10,000 \mathrm{WBC} / \mathrm{mm}^{3} \text { of blood) }\right. \\
\text { Mortality: in ICU }\end{array}$ \\
\hline Notes & $\begin{array}{l}\text { Personal contact with the main investigator provided data about } 23 \text { patients who were excluded from } \\
\text { the published paper (20 early extubations, three early deaths); these data are considered in the analy- } \\
\text { sis }\end{array}$
\end{tabular}

\section{Risk of bias}

\begin{tabular}{lll}
\hline Bias & Authors' judgement & Support for judgement \\
\hline $\begin{array}{l}\text { Allocation concealment } \\
\text { (selection bias) }\end{array}$ & Unclear risk & B - Unclear \\
\hline
\end{tabular}

Brun-Buisson 1989

\begin{tabular}{ll}
\hline Methods & Randomised trial \\
& Blinding: Open \\
& Randomisation method: odd and even birth year technique \\
& Accrual period: Apr 87 to May 87 \\
\hline Participants & Eligibility criteria: patients with an admission SAPS $>2$ and staying in the ICU more than 48 hrs \\
& Exclusion criteria: patients with severe neutropenia routinely receiving oral antibiotic prophylaxis \\
& Patients enrolled in the study: 133 \\
& Percentage of ventilated patients: $59 \%$
\end{tabular}


Brun-Buisson 1989 (Continued)

Length of stay in ICU, median: 3.5 days

Type of admission diagnosis: medical $75 \%$ surgical unscheduled $23 \%$ trauma $2 \%$

Severity score on admission: SAPS mean $=10.4$, ISS not available

Percentage of immunocompromised patients: $12.8 \%$

Percentage of patients treated with systemic antibiotic therapy (not stated in the protocol) in the first

three days: treatment $=41 \%$ CTR $=53 \%$

Stress ulcer prophylaxis applied: none

$\begin{array}{ll}\text { Interventions } & \text { Group A, Treatment: } \\ \text { - polymyxin E } 50 \mathrm{mg}, \text { neomycin } 1 \mathrm{~g}, \text { nalidixic acid } 1 \mathrm{~g}, \text { applied orally and enterally four times a day until } \\ \text { discharge } \\ \text { - Oropharyngeal disinfectant in intubated patients } \\ \text { Group B, CTR: } \\ \text { - Oropharyngeal disinfectant in intubated patients }\end{array}$

\begin{tabular}{|c|c|}
\hline \multirow[t]{2}{*}{ Outcomes } & $\begin{array}{l}\text { Respiratory infections (pneumonia acquired in the ICU or within } 48 \mathrm{hrs} \text { from discharge) } \\
\text { Diagnosis of infection was based on: } \\
\text { purulent sputum or tracheal aspirate associated with a new and persistent pulmonary infiltrate on X- } \\
\text { ray and the culture of at least } 10^{9} \mathrm{CFU} / \mathrm{l} \text { from a protected wedged catheter sample of bronchial aspi- } \\
\text { rate, temperature }>38^{\circ} \mathrm{C}, \mathrm{WBC}>10 \times 10^{9}\end{array}$ \\
\hline & Mortality: in ICU \\
\hline Notes & $\begin{array}{l}\text { Setting: acute and intermediate areas of a medical ICU } \\
\text { Personal contact with the main investigator provided data about } 47 \text { patients who were excluded from } \\
\text { the published paper (seven early deaths, one transferred, } 39 \text { other); these data are considered in the } \\
\text { analysis }\end{array}$ \\
\hline
\end{tabular}

\section{Risk of bias}

Bias Authors' judgement Support for judgement

\begin{tabular}{lll}
\hline $\begin{array}{l}\text { Allocation concealment } \\
\text { (selection bias) }\end{array}$ & High risk & C-Inadequate
\end{tabular}

(selection bias)

\section{Camus 2005}

$\begin{array}{ll}\text { Methods } & \text { Randomised trial } \\ & \text { Blinding: double } \\ & \text { Randomisation method: performed by computer } \\ & \text { Accrual period: April } 1996 \text { to October } 1998\end{array}$

Participants

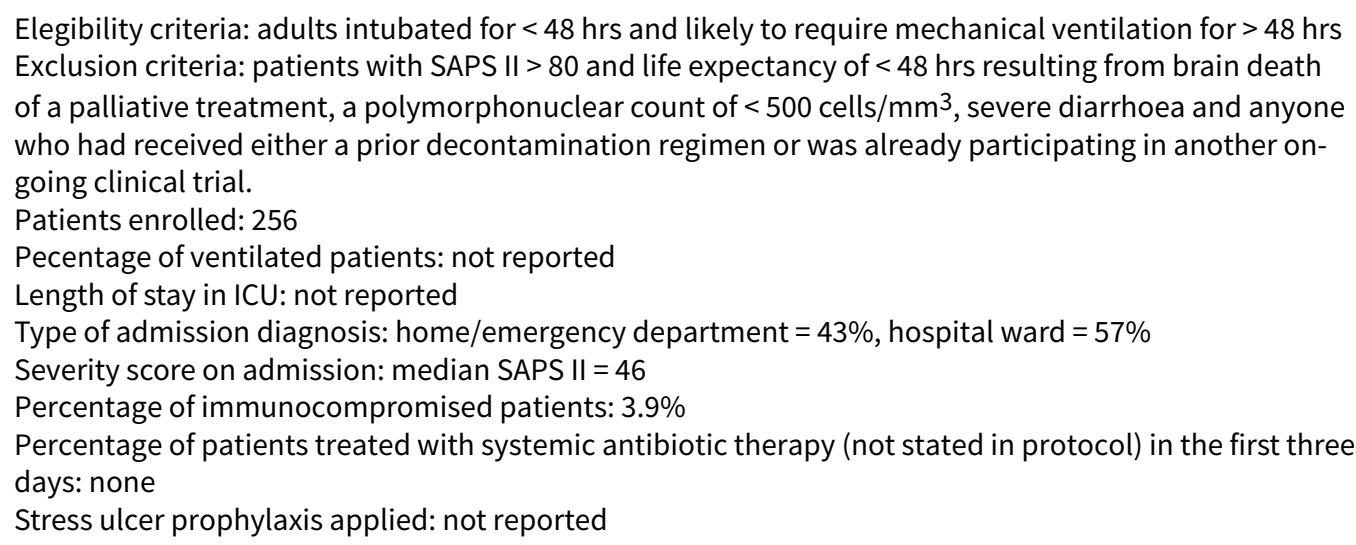
Exclusion criteria: patients with SAPS II $>80$ and life expectancy of $<48 \mathrm{hrs}$ resulting from brain death of a palliative treatment, a polymorphonuclear count of $<500$ cells $/ \mathrm{mm}^{3}$, severe diarrhoea and anyone who had received either a prior decontamination regimen or was already participating in another ongoing clinical trial.

Patients enrolled: 256

Pecentage of ventilated patients: not reported

Length of stay in ICU: not reported

Type of admission diagnosis: home/emergency department $=43 \%$, hospital ward $=57 \%$

Severity score on admission: median SAPS II $=46$

Percentage of immunocompromised patients: $3.9 \%$

Percentage of patients treated with systemic antibiotic therapy (not stated in protocol) in the first three days: none

Stress ulcer prophylaxis applied: not reported 
Camus 2005 (Continued)

Interventions

Group A - Treatment: solution containing $15 \mathrm{mg} / \mathrm{ml}$ polymyxin E and $10 \mathrm{mg} / \mathrm{ml}$ tobramycin Group B - Control: placebo

Outcomes

Respiratory infections: acquired infections

Mortality: in ICU

Notes

The study is a four arm, $2 \times 2$ factorial design. In this review we considered only two arms comparing SDD regimen versus placebo

\section{Risk of bias}

\begin{tabular}{lll}
\hline Bias & Authors' judgement & Support for judgement \\
\hline $\begin{array}{l}\text { Allocation concealment } \\
\text { (selection bias) }\end{array}$ & Unclear risk & B - Unclear \\
\hline
\end{tabular}

Cerra 1992

$\begin{array}{ll}\text { Methods } & \text { Randomised, placebo-controlled study } \\ & \text { Blinding: double blind } \\ & \text { Randomisation method: sealed envelopes } \\ & \text { Accrual period: Sept } 1988 \text { to Jan } 1990\end{array}$

Participants

Eligibility criteria: admission within 48 hrs from surgery, trauma or other acute event, expected stay at least five days, hypermetabolism $\left(\mathrm{VO}_{2}>140 \mathrm{ml} / \mathrm{m}^{2}\right.$ or urinary nitrogen excretion $>10 \mathrm{~g} /$ day $)$ without progressive MOSF (normal transaminases, stable bilirubin and creatinine)

Exclusion criteria: Cirrhosis, allergy to used drugs, chemo-radiotherapy, progressive MOSF, gastrointestinal leak or fistula

Patients enrolled in the study: 48

Percentage of ventilated patients: not available

ICU length of stay, median: not available

Type of admission diagnosis: surgical $=96 \%$ trauma $=4 \%$

Severity score on admission: not available

Percentage of immunocompromised patients: not available

Percentage of patients treated with systemic antibiotic therapy (not stated in the protocol) in the first

three days: not available

Stress ulcer prophylaxis applied: not available

\begin{tabular}{ll}
\hline Interventions & $\begin{array}{l}\text { Group A, Treatment: } \\
\text { - norfloxacin } 500 \mathrm{mg} \times 3 \text {, nystatin one million U x } 4 \text { applied enterally until discharge } \\
\text { Group B, CTR: } \\
\text { - Placebo }\end{array}$ \\
\hline Outcomes & Respiratory infections: not possible to evaluate \\
& Mortality \\
\hline Notes & $\begin{array}{l}\text { Personal contact with the main investigator provided data about two patients who were excluded from } \\
\text { the published paper for short length of stay); these data are considered in the analysis }\end{array}$
\end{tabular}

\section{Risk of bias}

Bias Authors' judgement Support for judgement


Cerra 1992 (Continued)
Allocation concealment
Low risk
A - Adequate
(selection bias)

\section{Cockerill 1992}

$\begin{array}{ll}\text { Methods } & \text { Randomised study. Intention-to-treat } \\ \text { Blinding: outcome assessor } \\ \text { Randomisation method: randomisation table at a remote site in the pharmacy } \\ \text { Accrual period: } 1986 \text { to } 1989\end{array}$

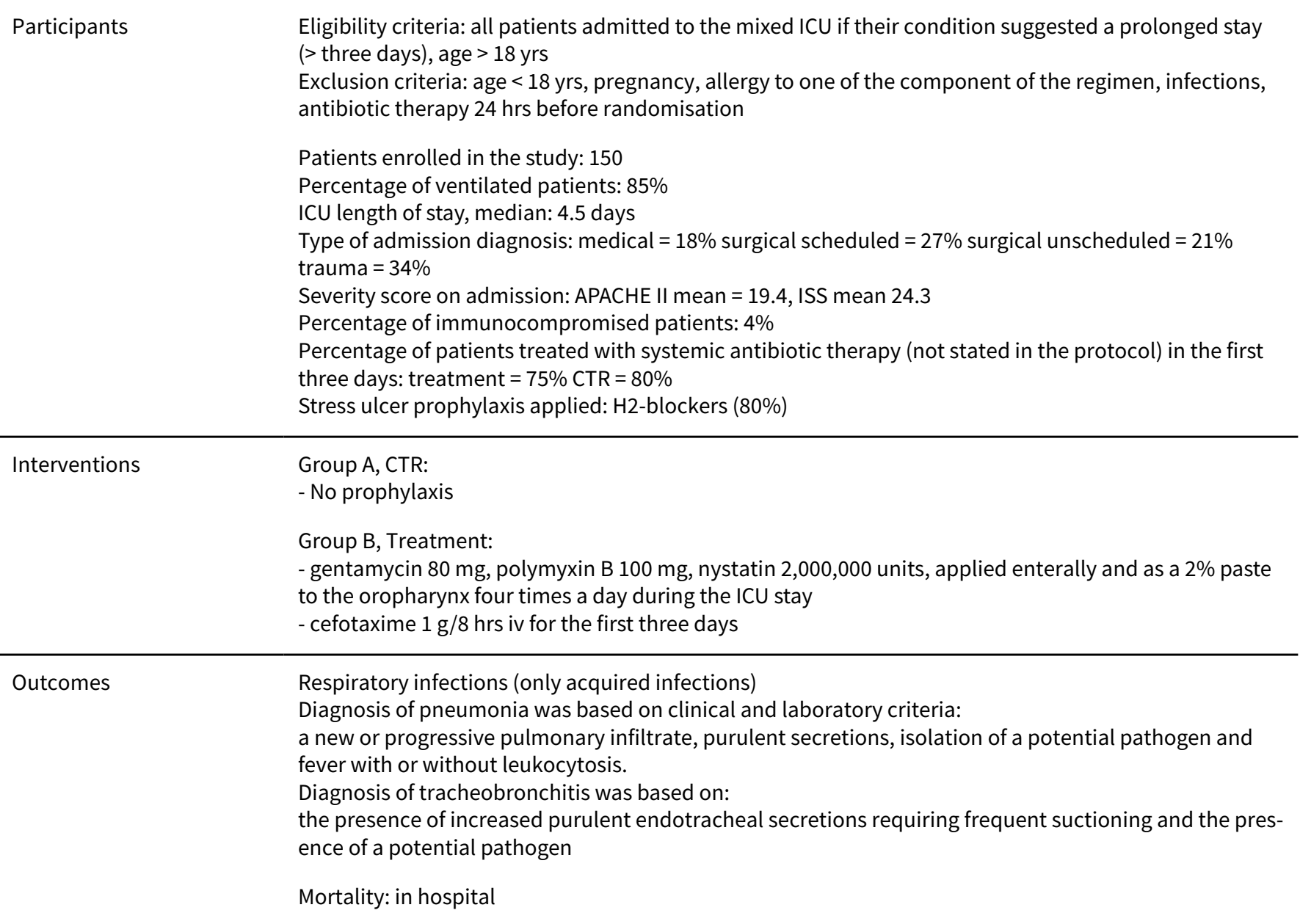

Notes

\section{Risk of bias}

\begin{tabular}{lll}
\hline Bias & Authors' judgement & Support for judgement \\
\hline $\begin{array}{l}\text { Allocation concealment } \\
\text { (selection bias) }\end{array}$ & Unclear risk & B - Unclear \\
\hline
\end{tabular}


de Jonge 2003

\begin{tabular}{|c|c|}
\hline Methods & $\begin{array}{l}\text { Randomised study } \\
\text { Blinding: Open } \\
\text { Randomisation method:computer-generated random-number codes kept in sealed envelopes }\end{array}$ \\
\hline \multirow[t]{14}{*}{ Participants } & $\begin{array}{l}\text { Eligibility criteria: adult patients admitted to ICU: with an expected stay of at least } 72 \text { hours and an ex- } \\
\text { pected duration of mechanical ventilation of at least } 48 \text { hours } \\
\text { Exclusion criteria: } \\
\text { previous admission in ICU within three months iper sensitivity to study medication, pregnancy and per- } \\
\text { ceived imminent death }\end{array}$ \\
\hline & Number of patients enrolled in the study: 934 \\
\hline & Percentage of ventilated patients: $85 \%$ \\
\hline & $\begin{array}{l}\text { Length of stay in ICU: } \text { median SDD group }=6.8 \text { days } \\
\text { control group }=8.5 \text { days }\end{array}$ \\
\hline & $\begin{array}{l}\text { Type of admission diagnosis: } \\
\text { medical: } 41 \% \\
\text { surgical urgent: } 25 \% \\
\text { surgical elective: } 34 \%\end{array}$ \\
\hline & Severity score at admission: \\
\hline & APACHE II mean = 18.7 \\
\hline & SAPS II in SDD group mean = 17.9 \\
\hline & SAPSII in control group mean = 17.1 \\
\hline & Percentage of immunocompromised patients \\
\hline & SDD group $=2.4 \%$ \\
\hline & control group = $1.7 \%$ \\
\hline & Information on prescribed antibiotics per 1,000 patients available in the main publication \\
\hline & No stress ulcer prophylaxis by protocol \\
\hline
\end{tabular}

SDD group: topical plus systemic treatment

Topical: oral paste containing $2 \%$ polymyxin E, $2 \%$ tobramycin, $2 \%$ amphotericin

$500 \mathrm{mg}$ amphotericin $\mathrm{B}$ through gastric tubes

Systemic: cefotaxime $1000 \mathrm{mg}$ four times daily for four days

Control group:

No antibiotic prophylaxis; antibiotic treatment based on clinical needs

\begin{tabular}{ll}
\hline Outcomes & Colonisation, antibiotic resistance \\
Mortality: in ICU and hospital
\end{tabular}

Notes

Patients were allocated to either an SDD or a control unit to prevent cross-colonisation between SDD and ICU control patients. Standard care was the same in the two units

\section{Risk of bias}

\begin{tabular}{lll}
\hline Bias & Authors' judgement & Support for judgement \\
\hline $\begin{array}{l}\text { Allocation concealment } \\
\text { (selection bias) }\end{array}$ & Low risk & A-Adequate \\
\hline
\end{tabular}

\section{Ferrer 1994}

Methods Randomised, placebo-controlled study


Ferrer 1994 (Continued)

Blinding: double blind

Randomisation method: computer generated table

Accrual period: Jan 91 to Mar 92

\begin{tabular}{|c|c|}
\hline Participants & $\begin{array}{l}\text { Eligibility criteria: all mechanically ventilated patients expected to remain intubated for more than } \\
\text { three days } \\
\text { Exclusion criteria: patients with HIV-related diseases or treated with antineoplastic chemotherapy as } \\
\text { well as patients who received transplants, extubation or death within } 72 \text { hrs } \\
\text { Number of patients enrolled in the study: } 101 \\
\text { Percentage of ventilated patients: } 100 \% \\
\text { Length of stay in ICU, median: } 7.5 \text { days } \\
\text { Type of admission diagnosis: medical } 66 \% \text { surgical scheduled } 6.9 \% \text { surgical unscheduled } 6.9 \% \text { trauma } \\
=19.8 \% \\
\text { Severity score admission: SAPS mean }=12.1, \text { ISS not available } \\
\text { Percentage of immunocompromised patients: } 0 \% \\
\text { Percentage of patients treated with systemic antibiotic therapy (not stated in the protocol) in the first } \\
\text { three days: not available } \\
\text { treatment = } 73 \% \text { CTR }=74 \% \\
\text { Stress ulcer prophylaxis applied: sucralfate except in patients with paralytic ileus or with upper gas- } \\
\text { trointestinal bleeding, who were treated with ranitidine }\end{array}$ \\
\hline Interventions & $\begin{array}{l}\text { Group A, Treatment: } \\
\text { - polymyxin E } 100 \mathrm{mg} \text {, tobramycin } 80 \mathrm{mg} \text {, amphotericin B } 500 \mathrm{mg} \text { applied enterally and, as a } 2 \% \text { paste, } \\
\text { to the oropharynx four times a day until extubation or death } \\
\text { - cefotaxime } 2 \mathrm{~g} / \text { day iv for the first four days or others if required } \\
\text { Group B, CTR: } \\
\text { - Placebo } \\
\text { - cefotaxime } 2 \mathrm{~g} / \text { day iv for the first four days or others if required } \\
\text { * patients infected on admission received adequate antibiotic treatment instead of cefotaxime }\end{array}$ \\
\hline Outcomes & $\begin{array}{l}\text { Respiratory infections (pneumonia acquired after four days of mechanical ventilation) } \\
\text { Diagnosis of infection was based on clinical criteria plus brush or BAL confirmation. } \\
\text { Clinical criteria: new or progressive pulmonary X-ray infiltrate for at least } 48 \mathrm{hrs} \text {, purulent tracheal se- } \\
\text { cretions, temperature }>38.5^{\circ} \mathrm{C} \text { and leukocytosis }>=12 \times 10^{9} \mathrm{WBC} / \text { or leukopenia }<=4 \times 10^{9} \\
\text { Mortality: in ICU }\end{array}$ \\
\hline Notes & $\begin{array}{l}\text { Personal contact with the main investigator provided data about } 21 \text { patients who were excluded from } \\
\text { the published paper ( } 14 \text { early extubations, six early deaths, one transfer); these data are considered in } \\
\text { the analysis }\end{array}$ \\
\hline
\end{tabular}

\section{Risk of bias}

Bias Authors' judgement Support for judgement

\begin{tabular}{lll}
\hline $\begin{array}{l}\text { Allocation concealment } \\
\text { (selection bias) }\end{array}$ & Unclear risk - Unclear
\end{tabular}

(selection bias)

Finch 1991

$\begin{array}{ll}\text { Methods } & \text { Randomised study } \\ & \text { Blinding: Open } \\ & \text { Randomisation method: sealed envelopes. Randomisation series made available to the hospital Phar- } \\ & \text { macy only }\end{array}$


Finch 1991 (Continued)

Accrual period: Aug 87 to Sept 89

Participants Eligibility criteria: all patients whose length of stay was $>60$ hrs, age $>16$ yrs

Exclusion criteria: none

Number of patients enrolled in the study: 49

Percentage of ventilated patients: not available

Length of stay in ICU: not available

Type of admission diagnosis: medical 59\% surgical scheduled $27 \%$ surgical unscheduled $10 \%$ trauma $=$ $4 \%$

Severity score on admission: SAPS mean $=10.5$, ISS not available

Percentage of immunocompromised patients: $22 \%$

Percentage of patients treated with systemic antibiotic therapy (not stated in the protocol) in the first three days: treatment $=58 \%$ CTR $=68 \%$

Stress ulcer prophylaxis applied: not available

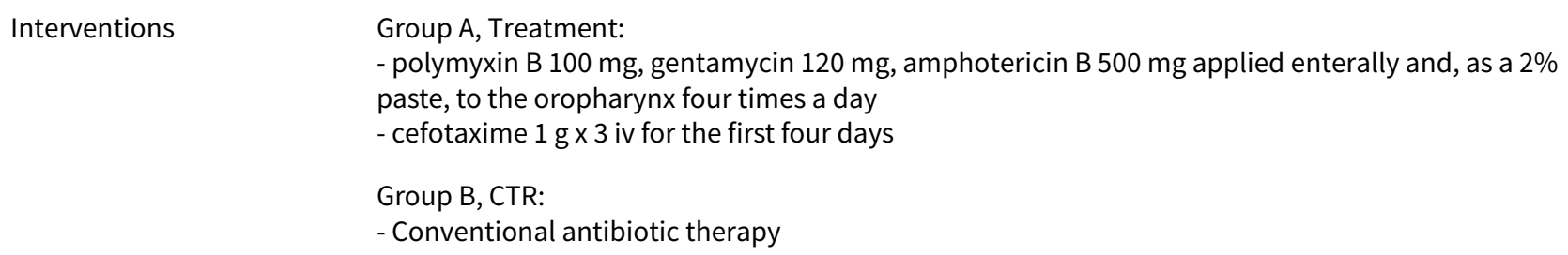

Notes

Personal contact with the main investigator provided information about mortality on five patients who were excluded from the published paper (one early extubation, two early deaths, one transferring, one unknown); these data are considered in the analysis. Data about respiratory infections in patients excluded from published paper are not available

\section{Risk of bias}

\begin{tabular}{lll}
\hline Bias & Authors' judgement & Support for judgement \\
\hline $\begin{array}{l}\text { Allocation concealment } \\
\text { (selection bias) }\end{array}$ & Low risk & A - Adequate \\
\hline
\end{tabular}

\section{Gastinne 1992}

\begin{tabular}{ll} 
Methods & $\begin{array}{l}\text { Randomised, placebo-controlled, multicenter (15 ICUs) study Intention to treat } \\
\text { Blinding: double blind } \\
\text { Randomisation method: a randomised list of consecutive treatment assignments, performed separate- } \\
\text { ly in each unit. } \\
\text { Accrual period: Feb } 90 \text { to Jun } 90\end{array}$ \\
\hline Participants & Eligibility criteria: all patients $>15$ yrs who required mechanical ventilation and with intubation per- \\
formed no more than 48 hrs before randomisation \\
Exclusion criteria: patients with ventilation for less than 24 hrs, drug or alcohol overdose, neutropenia \\
(WBC $\left.<500 / \mathrm{mm}^{3}\right)$, SAPS $>24$ or GCS $<4$, chronic degenerative central nervous system disease or spinal \\
cord injury above level of C4, acute severe enteropathy, pregnancy, participation in another ongoing
\end{tabular}


clinical trial, refusal of consent, patients with conditions in which survival was strongly related to status on admission

Number of patients enrolled in the study: 445

Percentage of ventilated patients: $100 \%$

Length of stay in ICU, median: 12 days

Type of admission diagnosis: medical $72 \%$ surgical scheduled $3 \%$ surgical unscheduled $10 \%$ trauma $=$ $15 \%$

Severity score on admission: SAPS mean $=13.5$, ISS not available GCS mean $=11.7$

Percentage of immunocompromised patients: $18 \%$

Percentage of patients treated with systemic antibiotic therapy (not stated in the protocol) in the first three days: treatment $=89 \%$ CTR $=84 \%$

Stress ulcer prophylaxis applied: sucralfate ( $43 \%$ patients), $\mathrm{H} 2$-blockers ( $13 \%$ patients)

\begin{tabular}{ll}
\hline Interventions & Group A, CTR: \\
- Placebo & \\
& Group B, Treatment: \\
- tobramycin $80 \mathrm{mg}$, polymyxin E $100 \mathrm{mg}$, amphotericin B $100 \mathrm{mg}$ applied enterally and, as a $2 \%$ paste, \\
to the oropharynx four times a day throughout the period of ventilation
\end{tabular}

\begin{tabular}{ll}
\hline Outcomes & Respiratory infections (pneumonia diagnosed within $48 \mathrm{hrs}$ and acquired): \\
& Diagnosis of infection was based on: \\
& purulent tracheal aspirate, temperature $>38.5^{\circ} \mathrm{C}$, peripheral leukocytosis $\left(>10,000 \mathrm{WBC} / \mathrm{mm} \mathrm{m}^{3}\right.$ of blood) \\
and a new and persistent infiltrate on the chest film. Brushing was recommended but not mandatory. & \\
& Mortality: in hospital
\end{tabular}

Notes

\section{Risk of bias}

\begin{tabular}{lll}
\hline Bias & Authors' judgement & Support for judgement \\
\hline $\begin{array}{l}\text { Allocation concealment } \\
\text { (selection bias) }\end{array}$ & Unclear risk & B - Unclear \\
\hline
\end{tabular}

Gaussorgues 1991

\begin{tabular}{|c|c|}
\hline Methods & $\begin{array}{l}\text { Randomised study. Intention to treat } \\
\text { Blinding: Open } \\
\text { Randomisation method: odd-even numbers } \\
\text { Accrual period: Sept } 88 \text { to Sept } 89\end{array}$ \\
\hline \multirow[t]{8}{*}{ Participants } & $\begin{array}{l}\text { Eligibility criteria: all patients admitted to the ICU, who required mechanical ventilation and inotropic } \\
\text { drugs for haemodynamic reasons } \\
\text { Exclusion criteria: neutropenia }\end{array}$ \\
\hline & Patients enrolled in the study: 118 \\
\hline & Percentage of ventilated patients: $100 \%$ \\
\hline & ICU length of stay: not available \\
\hline & $\begin{array}{l}\text { Type of admission diagnosis: } \text { medical }=83 \% \text { surgical scheduled }=17 \% \text { (all patients were infected on ad- } \\
\text { mission) }\end{array}$ \\
\hline & Severity score on admission: SAPS mean $=17.5$ \\
\hline & Percentage of immunocompromised patients: not available \\
\hline & $\begin{array}{l}\text { Percentage of patients treated with systemic antibiotic therapy (not stated in the protocol) in the first } \\
\text { three days: treatment }=100 \% \text { CTR }=100 \%\end{array}$ \\
\hline
\end{tabular}


Gaussorgues 1991 (Continued)

Stress ulcer prophylaxis applied: sucralfate $4 \mathrm{~g}$ to all patients

\begin{tabular}{|c|c|c|}
\hline Interventions & \multicolumn{2}{|c|}{$\begin{array}{l}\text { Group A, Treatment: } \\
\text { - polymyxin E } 36 \mathrm{mg} \text {, gentamycin } 80 \mathrm{mg} \text {, Vancomycin } 50 \mathrm{mg} \text {, amphotericin B } 500 \mathrm{mg} \text { applied enterally } \\
\text { four times a day until extubation } \\
\text { - amphotericin B, Clorexidine applied orally four times a day } \\
\text { - systemic antibiotic therapy }\end{array}$} \\
\hline Outcomes & \multicolumn{2}{|c|}{$\begin{array}{l}\text { Respiratory infections: not possible to evaluate } \\
\text { Mortality: in ICU }\end{array}$} \\
\hline Notes & \multicolumn{2}{|c|}{$\begin{array}{l}\text { All patients were infected on admission } \\
\text { Data about respiratory infections are not provided }\end{array}$} \\
\hline \multicolumn{3}{|l|}{ Risk of bias } \\
\hline Bias & Authors' judgement & Support for judgement \\
\hline $\begin{array}{l}\text { Allocation concealment } \\
\text { (selection bias) }\end{array}$ & High risk & C - Inadequate \\
\hline
\end{tabular}

Georges 1994

$\begin{array}{ll}\text { Methods } & \text { Randomised, placebo-controlled study } \\ & \text { Blinding: open } \\ & \text { Randomisation method: sealed envelopes } \\ & \text { Accrual period: Jun } 1990 \text { to April } 1992\end{array}$

Participants

Eligibility criteria: Polytrauma, expected mechanical ventilation for at least four days, age $>18$ years Exclusion criteria: Hypersensitivity to the used agents, protocol violation, obesity, ventilation < four days, patients on mechanical ventilation two days before admission, severe maxillo-facial lesions

Patients enrolled in the study: 138 , but only 64 patients were analysed

Length of stay in ICU, mean: 33 days

Percentage of ventilated patients: $100 \%$. Length of ventilation, mean: 16 days

Type of admission diagnosis: trauma $100 \%$

Severity score on admission: APACHE II mean $=15$, ISS $=41$

Percentage of immunocompromised patients: $0 \%$

Percentage of patients treated with systemic antibiotic therapy in the first 3 days: almost $100 \%$

Stress ulcer prophylaxis: $\mathrm{H} 2$-blockers

Group A:

Treatment: polymyxin E $75 \mathrm{mg}$, Netilmicin $150 \mathrm{mg}$, amphotericin B $400 \mathrm{mg}$ applied enterally four times a day and, as a $2 \%$ paste, to the oropharynx until extubation

- Systemic antibiotic prophylaxis was free

Group B: CTR

- Placebo

- Systemic antibiotic prophylaxis was free

Outcomes

Respiratory infections (acquired pneumonia)

Diagnosis of infection was based on: 
Fever $>38.5^{\circ} \mathrm{C}$, leukocytosis $>12000 / \mathrm{mm}^{3}$, new infiltrates in the chest X-rays, purulent pulmonary secretions, positive bacteriologic findings $\left(>10^{\wedge} 3 \mathrm{CFU} / \mathrm{ml}\right.$ ) obtained through a protected catheter

Mortality: in ICU and hospital

Notes

Antibiotic prophylaxis was free and almost all patients of both groups were treated with systemic antibiotics

74 potentially eligible patients were excluded from analysis; it is not evident if this happened before or after randomisation; these data are not available

\section{Risk of bias}

\begin{tabular}{lll}
\hline Bias & Authors' judgement & Support for judgement \\
\hline $\begin{array}{l}\text { Allocation concealment } \\
\text { (selection bias) }\end{array}$ & Low risk & A-Adequate \\
\hline
\end{tabular}

\section{Hammond 1992}

$\begin{array}{ll}\text { Methods } & \text { Randomised, placebo-controlled study } \\ & \text { Blinding: double blind } \\ & \text { Randomisation method: computer generated random numbers. } \\ & \text { Accrual period: Jan } 89 \text { to Dec } 90\end{array}$

Accrual period: Jan 89 to Dec 90

\begin{tabular}{|c|c|}
\hline Participants & $\begin{array}{l}\text { Eligibility criteria: expected intubation for longer than } 48 \text { hrs and stay in ICU for at least five days } \\
\text { Exclusion criteria: hypersensitivity to the study drugs, patients with asthma, drug overdose and pa- } \\
\text { tients admitted electively after surgery } \\
\text { Number of patients enrolled in the study: } 322 \\
\text { Percentage of ventilated patients: } 100 \% \\
\text { Length of stay in ICU, median: } 11 \text { days } \\
\text { Type of admission diagnosis: medical } 55 \% \text { surgical scheduled } 3 \% \text { surgical unscheduled } 11 \% \text { trauma = } \\
31 \% \\
\text { Severity score on admission: APACHE II mean }=13.9, \text { ISS mean }=28.7 \\
\text { Percentage of immunocompromised patients: } 0.8 \% \\
\text { Percentage of patients treated with systemic antibiotic therapy (not stated in the protocol) in the first } \\
\text { three days: treatment }=54 \% \text { CTR }=58 \% \\
\text { Stress ulcer prophylaxis applied: none, H2-blockers only to high risk patients }\end{array}$ \\
\hline Interventions & $\begin{array}{l}\text { Group A, Treatment: } \\
\text { - polymyxin E } 100 \mathrm{mg} \text {, tobramycin } 80 \mathrm{mg} \text {, amphotericin B } 500 \mathrm{mg} \text { applied enterally and, as a } 2 \% \text { gel, to } \\
\text { the oropharynx four times a day until } 48 \text { hrs after extubation } \\
\text { - cefotaxime } 1 \mathrm{~g} \times 3 \text { iv for the first three days to patients untreated on admission } \\
\text { Group B, CTR: } \\
\text { - Placebo } \\
\text { - cefotaxime } 1 \mathrm{~g} \times 3 \text { iv for the first three days to patients untreated on admission }\end{array}$ \\
\hline Outcomes & $\begin{array}{l}\text { Respiratory infections (infections acquired after } 48 \mathrm{hrs} \text { ) } \\
\text { Diagnosis of pneumonia was based on: } \\
\text { a new infiltrate on X-ray and purulent bronchial secretions with many leukocytes, temperature }>38^{\circ} \mathrm{C} \text {, } \\
\text { WBC }>1010 / \mathrm{l} \text {, substantial number of organism on gram stain with a pure growth culture from tracheal } \\
\text { aspirate, deterioration of gas exchange of }>2 \mathrm{kPa} \\
\text { Diagnosis of bronchial infection was based on: } \\
\text { all the previous criteria except the X-ray changes }\end{array}$ \\
\hline & Mortality: in hospital \\
\hline
\end{tabular}


Hammond 1992 (Continued)

Notes
Personal contact with the main investigator provided data on 82 patients who were excluded and separately considered in the published paper (78 short stay, three protocol violation, one unknown); these data are considered in the analysis

\section{Risk of bias}

\begin{tabular}{lll}
\hline Bias & Authors' judgement & Support for judgement \\
\hline $\begin{array}{l}\text { Allocation concealment } \\
\text { (selection bias) }\end{array}$ & Unclear risk & B - Unclear \\
\hline
\end{tabular}

\section{Jacobs 1992}

\begin{tabular}{ll}
\hline Methods & Randomised study \\
& Blinding: open \\
& Randomisation method: sealed envelopes. \\
& Accrual period: Jul 89 to Aug 90 \\
\hline Participants & Eligibility criteria: expected stay in ICU > three days \\
& Exclusion criteria: none \\
& Patients enrolled in the study: 91 \\
& Percentage of ventilated patients: $100 \%$ \\
& ICU length of stay, median: unknown \\
& Type of admission diagnosis: medical = $25 \%$ surgical = 57\% trauma $=18 \%$ (high percentage of neuro- \\
& logic and neurosurgical patients $52 \%)$ \\
& Severity score on admission: APACHE II mean $=17.5$, ISS not available \\
& Percentage of immunocompromised patients: unknown \\
& Percentage of patients treated with systemic antibiotic therapy (not stated in the protocol) in the first \\
& three days: next to $100 \%$ \\
& Stress ulcer prophylaxis applied: policy of maintenance a low gastric $\mathrm{pH}, \mathrm{H} 2$-blockers only if peptic ul- \\
& cer or steroid therapy (33\%), sucralfate $4 \mathrm{~g}$ to all patients not on enteral feeding
\end{tabular}

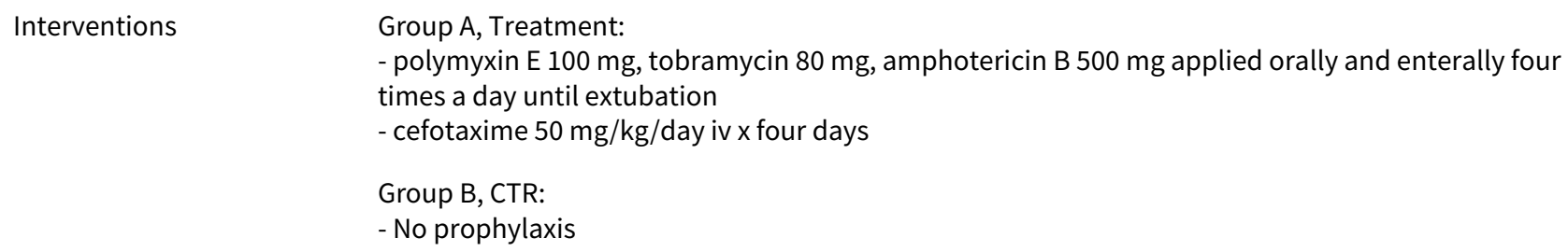

\section{Risk of bias}

Bias Authors' judgement Support for judgement


Jacobs 1992 (Continued)
Allocation concealment
Low risk
A - Adequate
(selection bias)

\section{Kerver 1988}

$\begin{array}{ll}\text { Methods } & \text { Randomised study } \\ & \text { Blinding: open } \\ & \text { Randomisation method: odd/even numbers } \\ & \text { Accrual period: Jan } 85 \text { to May } 86 \\ \text { Participants } & \text { Eligibility criteria: all patients admitted to the surgical ICU who required care }>\text { five days } \\ & \text { Exclusion criteria: none } \\ & \text { Patients enrolled in the study: } 96 \\ & \text { Percentage of ventilated patients: } 100 \% \\ & \text { ICU length of stay, not available } \\ & \text { Type of admission diagnosis: surgical }=60 \% \text { trauma }=28 \% \text { other }=12 \% \\ & \text { Severity score on admission: APACHE II mean }=14.8, \text { ISS not available } \\ & \text { Percentage of immunocompromised patients: not available } \\ & \text { Percentage of patients treated with systemic antibiotic therapy (not stated in the protocol) in the first } \\ \text { three days: about } 85 \% & \text { Stress ulcer prophylaxis applied: not available }\end{array}$

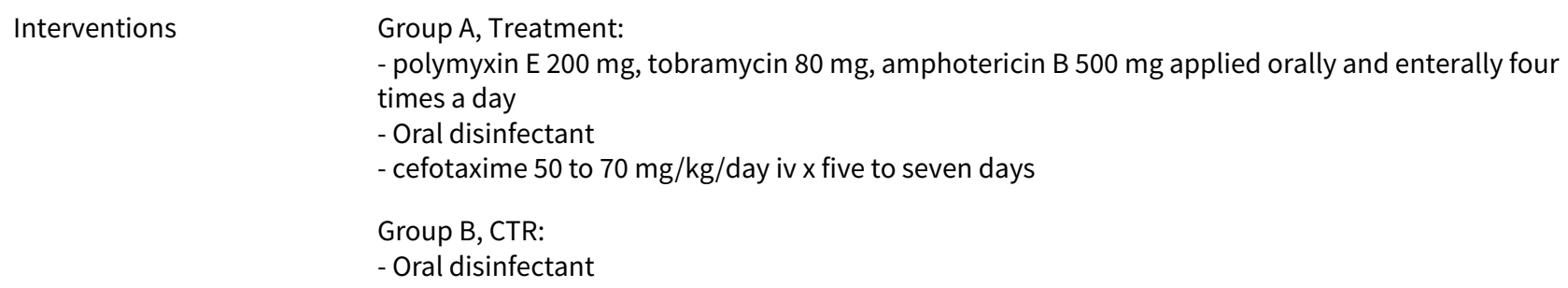
the same day: rectal temperature $>38.5^{\circ} \mathrm{C}$ for at least $12 \mathrm{hrs}$, WBC count $>10 \times 10^{3}$ or $<4 \times 10^{3} / \mathrm{mcl}$, at least $3 \%$ band forming granulocytes, unexplained decrease in platelet count $<100,000 / \mathrm{mcl}$, deterioration of renal function due to acute tubular necrosis, unexplained decrease in systolic blood pressure of $>30 \mathrm{mmHg}$, progressive respiratory failure

Mortality

\section{Risk of bias}

\begin{tabular}{lll}
\hline Bias & Authors' judgement & Support for judgement \\
\hline $\begin{array}{l}\text { Allocation concealment } \\
\text { (selection bias) }\end{array}$ & High risk & C - Inadequate \\
\hline
\end{tabular}

\section{Korinek 1993}

\section{Methods}

Randomised, placebo-controlled, dual-centre study Blinding: double blind

Randomisation method: randomisation performed by the hospital pharmacist on each unit separately 
Korinek 1993 (Continued)

Accrual period: Mar 89 to Sep 90

Participants Eligibility criteria: all comatosed patients with emergency admission to two neurosurgical ICUs and intubated within $24 \mathrm{hrs}$ for at least five days, age $>16 \mathrm{yrs}$

Exclusion criteria: age < 16 yrs, known immunosuppression, antibiotic treatment during the two weeks preceding ICU admission, serious injury of oropharyngeal mucosa or epistaxis, abnormal chest X-ray on admission, extubation or infection occurring within the first five days of neurosurgical care

Number of patients enrolled in the study: 191

Percentage of ventilated patients: $100 \%$

Length of stay in ICU, mean: 26 days

Type of admission diagnosis: surgical scheduled $11 \%$ surgical unscheduled $39 \%$ trauma $50 \%$

Severity score on admission: SAPS mean $=10.9$, ISS not available

Percentage of immunocompromised patients: $0 \%$

Percentage of patients treated with systemic antibiotic therapy (not stated in the protocol) in the first three days: treatment $=0 \%$ CTR $=0 \%$

Stress ulcer prophylaxis applied: sucralfate (32\%), antiacids (14\%), H2-blockers (20\%) until enteral feeding was started

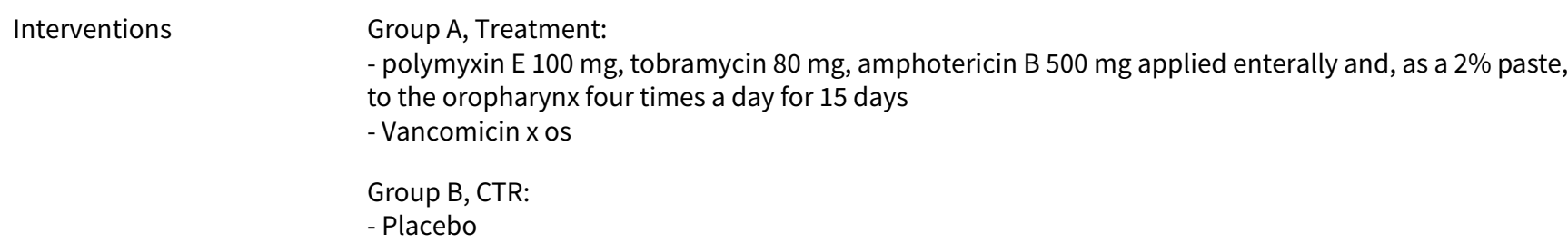

The non-absorbable antibiotics were discontinued if any infection requiring a parenteral antibiotic treatment occurred and at the time of patient's extubation

\begin{tabular}{|c|c|}
\hline Outcomes & $\begin{array}{l}\text { Respiratory infections (pneumonia acquired after five days) } \\
\text { Diagnosis of infection was based on: } \\
\text { fever }>38.5^{\circ} \mathrm{C} \text {, leukocytosis }>12,000 \text { cells } / \mathrm{mm}^{3} \text {, purulent sputum, new and persistent infiltrates on } \\
\text { chest X-ray and a culture of }>10^{3} \mathrm{CFU} / \mathrm{ml} \text { obtained with either brush or plugged telescoping catheter } \\
\text { Mortality: in ICU }\end{array}$ \\
\hline Notes & $\begin{array}{l}\text { Setting: neurosurgical ICU } \\
\text { Personal contact with the main investigator provided data about } 68 \text { patients who were excluded from } \\
\text { the published paper (early extubation, early death, protocol violation, transferring, other); these data } \\
\text { are considered in the analysis }\end{array}$ \\
\hline
\end{tabular}

\section{Risk of bias}

\begin{tabular}{lll}
\hline Bias & Authors' judgement & Support for judgement \\
\hline $\begin{array}{l}\text { Allocation concealment } \\
\text { (selection bias) }\end{array}$ & Unclear risk & B - Unclear \\
\hline
\end{tabular}

\section{Krueger 2002}

\begin{tabular}{ll}
\hline Methods & $\begin{array}{l}\text { Randomised, double blind, placebo-controlled, double centre study } \\
\text { Randomisation method: computer-generated randomisation } \\
\text { Accrual period: Apr } 89 \text { to Mar } 91\end{array}$ \\
\hline Participants & $\begin{array}{l}\text { Eligibility criteria: expected stay in ICU > two days and at least one risk factor for infection } \\
\text { Exclusion criteria: patients expected to die within } 48 \text { hrs or randomisation was not achieved within } 12 \\
\text { hrs after admission to ICU. }\end{array}$ \\
\hline
\end{tabular}


Patients enrolled in the study: 546, 19 patients were excluded leaving 527 patients for analysis

Percentage of ventilated patients: not available

ICU length of stay: 10 days for both groups

Type of admission diagnosis: surgical

Severity score on admission: APACHE II mean $=20$, ISS not available

Percentage of immunocompromised patients: not available

Percentage of patients treated with systemic antibiotic therapy (not stated by protocol) in the first

three days: not available

Stress ulcer prophylaxis applied: sucralfate to all patients

\begin{tabular}{|c|c|c|}
\hline Interventions & \multicolumn{2}{|c|}{$\begin{array}{l}\text { Group A, Treatment: } \\
\text { - polymyxin B } 50 \mathrm{mg} \text {, gentamycin } 80 \mathrm{mg} \text {, applied nasally, orally and enterally four times a day during } \\
\text { the ICU stay } \\
\text { - ciprofloxacin } 400 \mathrm{mg} \times 2 \text { iv x four days to uninfected patients } \\
\text { Group B, CTR: } \\
\text { - Placebo applied nasally, orally and enterally } \\
\text { - Placebo iv to uninfected patients }\end{array}$} \\
\hline Outcomes & \multicolumn{2}{|c|}{ Respiratory infections (acquired pneumonia) } \\
\hline Notes & \multicolumn{2}{|c|}{ Information about accrual period and severity score was reported on an abstract previously published } \\
\hline \multicolumn{3}{|l|}{ Risk of bias } \\
\hline Bias & Authors' judgement & Support for judgement \\
\hline $\begin{array}{l}\text { Allocation concealment } \\
\text { (selection bias) }\end{array}$ & Low risk & A - Adequate \\
\hline
\end{tabular}

\section{Laggner 1994}

$\begin{array}{ll}\text { Methods } & \text { Randomised, placebo-controlled study } \\ \text { Blinding: double blind } \\ \text { Randomisation method: computer generated randomisation in time blocks. Open } \\ \text { Accrual period: Aug } 87 \text { to Nov } 90\end{array}$

Participants

Eligibility criteria: expected ventilation for five days, age $>18 \mathrm{yrs}$ and $<80 \mathrm{yrs}$, acute onset of respiratory failure

Exclusion criteria: age $<18 \mathrm{yrs}$ and $>80 \mathrm{yrs}$, bleeding of the nasopharynx and of the upper gastrointestinal tract on admission, stress ulcer prophylaxis with other drug therapy than sucralfate, mechanical ventilation for less than five days, patients on enteral nutrition or with known allergy to sucralfate or gentamicin

Number of patients enrolled in the study: 88 , but only 67 patients were analysed

Percentage of ventilated patients: $100 \%$

Length of stay in ICU, mean: 28.8 days

Type of admission diagnosis: medical $88 \%$ surgical scheduled $9 \%$ surgical unscheduled $1 \%$ trauma $=$ $2 \%$

Severity score on admission: APACHE II mean $=23$, ISS not available

Percentage of immunocompromised patients: $15 \%$

Percentage of patients treated with systemic antibiotic therapy (not stated in the protocol) in the first three days: $100 \%$

Stress ulcer prophylaxis applied: sucralfate 
- gentamycin $40 \mathrm{mg}$, amphotericin B $100 \mathrm{mg}$ applied to the oropharynx four times a day until extuba-

tion

- Oropharyngeal disinfectant

- aminopenicillin and clavulanic acid or other appropriate regimens

Group B, CTR:

- Placebo

- Amphotericin B $100 \mathrm{mg}$

- Oropharyngeal disinfectant

- Aminopenicillin and clavulanic acid or other appropriate regimens

\begin{tabular}{|c|c|}
\hline Outcomes & $\begin{array}{l}\text { Respiratory infections (acquired pneumonia): } \\
\text { Diagnosis of infection was based on: } \\
\text { appearance of a new infiltrate on the chest film with concomitant tracheal colonisation, fever }>38^{\circ} \mathrm{C} \\
\text { and }>15,000 \text { or }<5,000 \mathrm{WBC} / \mathrm{mm}^{3} \text { of blood }\end{array}$ \\
\hline & Mortality: in ICU \\
\hline Notes & $\begin{array}{l}\text { Data about } 21 \text { patients who were excluded from the published paper (18 short mechanical ventilation, } \\
\text { three early enteral nutrition) are not available }\end{array}$ \\
\hline
\end{tabular}

\section{Risk of bias}

\section{Bias}

Authors' judgement Support for judgement

Allocation concealment Unclear risk B-Unclear

(selection bias)

\section{Lingnau 1997}

Randomised, placebo-controlled study with three arms (one control arm and two treatment arms). In-
tention to treat
Blinding: double blind
Randomisation method: continuous random numbers assigned to blinded study drugs or vehicle by
Biometric department.
Accrual period: Aug 89 to Jan 94

Participants Eligibility criteria: non infected trauma patients, age $>18 \mathrm{yrs}$, expected ventilation for at least two days, expected ICU stay for at least three days, ISS $>16$ and $<74$, inclusion within $24 \mathrm{hrs}$ of admission Exclusion criteria: isolated brain injury, prior antibiotic treatment, history of infection

Patients enrolled in the study: 357 Percentage of ventilated patients: $100 \%$

ICU length of stay, mean: 20 days

Type of admission diagnosis: trauma $=100 \%$

Severity score on admission: APACHE II mean $=15.6$, ISS mean $=35.2$

Percentage of immunocompromised patients: $0 \%$

Percentage of patients treated with systemic antibiotic therapy (not stated by protocol) in the first

three days: treatment $1=2 \%$ treatment $2=2 \% \mathrm{CTR}=6 \%$

Stress ulcer prophylaxis applied: free

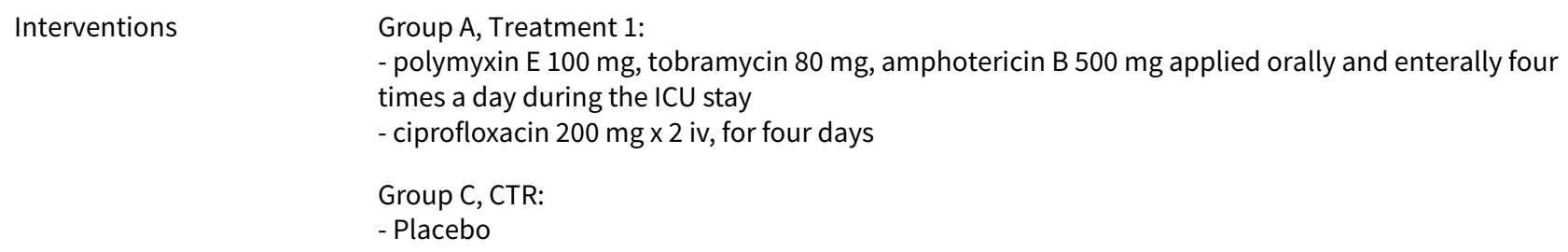


Lingnau 1997 (Continued)

- ciprofloxacin $200 \mathrm{mg} \times 2$ iv, for four days

\begin{tabular}{ll}
\hline Outcomes & Respiratory infections (acquired pneumonia): \\
& Diagnosis of infection was based on: \\
& concomitant occurrence of purulent sputum, positive cultures of bronchial secretions and deteriora- \\
& tion of lung function \\
& Mortality: in ICU \\
\hline Notes & This three arm study has been split in two comparisons; the control group C has been used twice: \\
& comparison Lingnau a (group A versus group C) \\
comparison Lingnau b (group B versus group C)
\end{tabular}

\section{Risk of bias}

\begin{tabular}{lll}
\hline Bias & Authors' judgement & Support for judgement \\
\hline $\begin{array}{l}\text { Allocation concealment } \\
\text { (selection bias) }\end{array}$ & Unclear risk & B - Unclear \\
\hline
\end{tabular}

\section{Lingnau 1997b}

\begin{tabular}{ll}
\hline Methods & see Lingnau 1997 \\
\hline Participants & see Lingnau 1997 \\
& Only two groups of patients, group B and C, are considered in this comparison, totaling 267 patients \\
\hline
\end{tabular}

\begin{tabular}{|c|c|c|}
\hline Interventions & \multicolumn{2}{|c|}{$\begin{array}{l}\text { Group B, Treatment 2: } \\
\text { - polymyxin E } 100 \mathrm{mg} \text {, ciprofloxacin } 50 \mathrm{mg} \text {, amphotericin B } 500 \mathrm{mg} \text { applied orally and enterally four } \\
\text { times a day during the ICU stay } \\
\text { - ciprofloxacin } 200 \mathrm{mg} \times 2 \text { iv, for four days }\end{array}$} \\
\hline Outcomes & \multicolumn{2}{|l|}{ see Lingnau 1997} \\
\hline Notes & \multicolumn{2}{|l|}{ see Lingnau 1997} \\
\hline \multicolumn{3}{|l|}{ Risk of bias } \\
\hline Bias & Authors' judgement & Support for judgement \\
\hline $\begin{array}{l}\text { Allocation concealment } \\
\text { (selection bias) }\end{array}$ & Unclear risk & D - Not used \\
\hline
\end{tabular}

Palomar 1997

$\begin{array}{ll}\text { Methods } & \text { Randomised, multicentric (10 ICUs) study with three arms (one treatment arm and two control arms; } \\ \text { one control arm was excluded from meta-analysis because it was the only one receiving sucralfate) } \\ \text { Blinding: open } \\ \text { Randomisation method: sealed envelopes. } \\ \text { Accrual period: Jul } 89 \text { to Aug } 91\end{array}$


Palomar 1997 (Continued)

Participants
Eligibility criteria: patients requiring mechanical ventilation for more than four days, not infected at the time of entry and not receiving antibiotic therapy

Exclusion criteria: ARDS, leukopenia, pregnancy

Number of patients enrolled in the study: 97

Percentage of ventilated patients: $100 \%$

Length of stay in ICU, median 10 days

Type of admission diagnosis: medical $40 \%$ surgical $10 \%$ trauma $50 \%$

Severity score on admission: APACHE II mean $=16.8$, ISS not available

Percentage of immunocompromised patients: $0 \%$

Percentage of patients treated with systemic antibiotic therapy (not stated in the protocol) in the first three days: treatment $=0 \%$ CTR $=6 \%$

Stress ulcer prophylaxis applied: sucralfate to one control group (excluded from meta-analysis), antiacids or $\mathrm{H} 2$-blockers to the two other groups

$\begin{array}{ll}\text { Outcomes } & \text { Respiratory infections (acquired infections) } \\ & \text { Diagnosis of pneumonia was based on the CDC criteria of } 1980 \text { (clinical or radiologic suspicion with: } \\ \text { purulent sputum, organism isolated from blood culture, isolation of pathogen from tracheal aspirate, } & \text { brush or biopsy. Bacteriologic evaluation was performed with brush or BAL in } 50 \% \text { of patients) } \\ \text { Diagnosis of tracheobronchitis was based on the CDC criteria of } 1980 \\ \text { Mortality: in ICU }\end{array}$

Notes

Personal contact with the main investigator provided data about 16 patients who were excluded from the published paper (seven early extubations, five early deaths, three protocol violation, one other); these data are considered in the analysis

\section{Risk of bias}

\begin{tabular}{lll}
\hline Bias & Authors' judgement & Support for judgement \\
\hline $\begin{array}{l}\text { Allocation concealment } \\
\text { (selection bias) }\end{array}$ & Low risk & A - Adequate \\
\hline
\end{tabular}

Pneumatikos 2002

\begin{tabular}{ll}
\hline Methods & Randomised, placebo-controlled \\
& Blinding: outcome assessor \\
& Randomisation method: not stated \\
\hline Participants & Elegibility criteria: patients with multiple trauma admitted to the intensive care unit who required intu- \\
& bation and had an expected time for mechanical ventilation exceeding five days \\
& Absence of cardiopulmonary disease, negative chest radiography, and a $\mathrm{PaO}_{2} / \mathrm{FIO}_{2}$ ratio higher than \\
& $300 \mathrm{mmHg}$
\end{tabular}


Pneumatikos 2002 (Continued)

Patients enrolled in the study: 61

Percentage of ventilated patients: $100 \%$

ICU length of stay, median:

Treatment $=16$ days

Control $=23$ days

Type of admission diagnosis:

trauma $=100 \%$

Severity score on admission: APACHE II

treatment $=18.1$

control $=19.1$

Percentage of immunocompromised patients: not stated

Percentage of patients treated with systemic antibiotic therapy:

not stated

Stress ulcer prophylaxis applied: $\mathrm{H} 2$ blockers or sucralfate

Treatment $=26 \%$

Control $=19 \%$

\begin{tabular}{ll}
\hline Interventions & Group A, treatment: \\
& polymyxin $73 \mathrm{mg}$, \\
& tobramycin $73 \mathrm{mg}$, amphotericin $500 \mathrm{ml}$ in $500 \mathrm{ml} 0.9$ saline solution at an infusion rate of $2 \mathrm{ml} / \mathrm{hr}$ in the \\
& subglottic area for the entire period of the study \\
& Group B CTR: \\
placebo
\end{tabular}

Outcomes

Ventilator associated pneumonia (VAP) defined as presence of new and persistent pulmonary infiltrates in addition to two of the following criteria: body temperature $>38.3^{\circ} \mathrm{C}$, leukocytes $/ \mathrm{mm}^{3}$ ) or leukopenia ( $<4000$ leukocytes $/ \mathrm{mm}^{3}$ ) and purulent tracheal secretions. The diagnosis of VAP was confirmed by quantitative cultures.

Mortality: not specified

Notes

\section{Risk of bias}

\begin{tabular}{lll}
\hline Bias & Authors' judgement & Support for judgement \\
\hline $\begin{array}{l}\text { Allocation concealment } \\
\text { (selection bias) }\end{array}$ & Unclear risk & B - Unclear \\
\hline
\end{tabular}

\section{Pugin 1991}

Methods Randomised, placebo-controlled study

Blinding: double blind

Randomisation method: sealed envelopes

Accrual period: Apr 89 to Nov 89

Participants

Eligibility criteria: all adult patients admitted to the surgical ICU, at high risk of developing pneumonia and intubated for more than $48 \mathrm{hrs}$

Exclusion criteria: organ transplantation

Number of patients enrolled in the study: 79

Percentage of ventilated patients: $100 \%$

Length of stay in ICU, mean 13.8 days 
Pugin 1991 (Continued)

Type of admission diagnosis: medical $11 \%$ surgical scheduled $11 \%$ surgical unscheduled $22 \%$ trauma $56 \%$

Severity score on admission: APACHE II mean $=15.2$, ISS not available

Percentage of immunocompromised patients: not available

Percentage of patients treated with systemic antibiotic therapy (not stated in the protocol) in the first three days: treatment $=46 \%$ CTR $=53 \%$

Stress ulcer prophylaxis applied: sucralfate $(61 \%)$, ranitidine $(11 \%)$

\begin{tabular}{|c|c|}
\hline \multirow[t]{2}{*}{ Interventions } & $\begin{array}{l}\text { Group A, Treatment: } \\
\text { - polymyxin B sulfate } 150 \mathrm{mg} \text {, neomycin sulfate } 1 \mathrm{~g} \text {, vancomycin hydrochloride } 1 \mathrm{~g} \text { applied as a solution } \\
\text { to the retropharynx six times a day within } 24 \text { hrs after intubation until extubation or death } \\
\text { Group B, CTR: } \\
\text { - Placebo }\end{array}$ \\
\hline & $\begin{array}{l}\text { Withdrawal from the study was possible at any time if the treating physicians estimated that there was } \\
\text { any problem related to administration of the drugs or side effects }\end{array}$ \\
\hline \multirow[t]{2}{*}{ Outcomes } & $\begin{array}{l}\text { Respiratory infections (pneumonia acquired after } 48 \mathrm{hrs} \text { ): Pneumonia are defined by the "clinical pul- } \\
\text { monary infections score" (CPIS) greater or equal to seven during the course of intubation and that re- } \\
\text { mained elevated (=7) for at least three days (i.e. for two consecutive measurements) }\end{array}$ \\
\hline & Mortality: in hospital \\
\hline Notes & $\begin{array}{l}\text { Personal contact with the main investigator provided data about } 27 \text { patients who were excluded from } \\
\text { the published paper ( } 20 \text { early extubations, seven early deaths); these data are considered in the analy- } \\
\text { sis }\end{array}$ \\
\hline
\end{tabular}

Risk of bias

\begin{tabular}{lll}
\hline Bias & Authors' judgement & Support for judgement \\
\hline $\begin{array}{l}\text { Allocation concealment } \\
\text { (selection bias) }\end{array}$ & Low risk & A - Adequate \\
\hline
\end{tabular}

Quinio 1995

\section{Methods}

Randomised, placebo-controlled study. Intention to treat

Blinding: double blind

Randomisation method: randomisation made by the Pharmacy's Service according to computer generated random numbers.

Accrual period: Jan 91 to Jan 93
Eligibility criteria: trauma patients intubated within $24 \mathrm{hrs}$ and ventilated for more than $48 \mathrm{hrs}$, ICU stay $>$ five days and decontamination for more than four days

Exclusion criteria: age $<16 \mathrm{yrs}$, antibiotic treatment in the week precedent to ICU admission, pregnancy

Number of patients enrolled in the study: 149

Percentage of ventilated patients: $100 \%$

Length of stay in ICU, mean $=20.5$ days

Type of admission diagnosis: medical $2 \%$ trauma $98 \%$

Severity score on admission: SAPS mean $=11.2$, ISS mean $=31.3$

GCS mean 6.5

Percentage of immunocompromised patients: $0 \%$

Percentage of patients treated with systemic antibiotic therapy (not stated in the protocol) in the first three days: treatment $=35 \%$ CTR $=26 \%$

Stress ulcer prophylaxis applied: sucralfate until enteral feeding was effective, $\mathrm{H}$ 2-blockers in high risk patients 
Quinio 1995 (Continued)

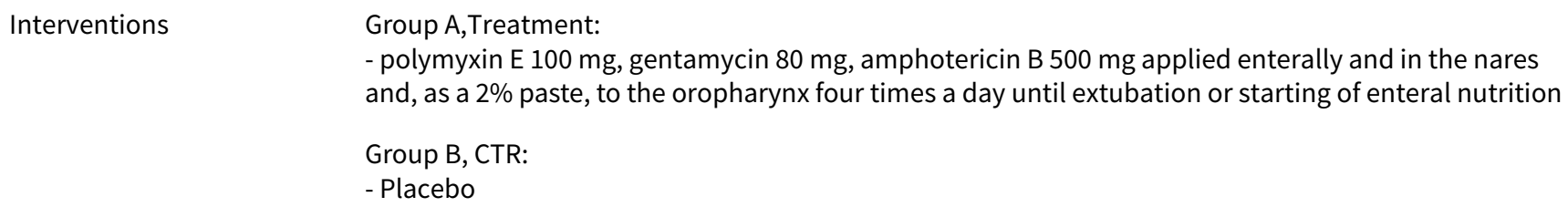

\section{Outcomes}

Respiratory infections (pneumonia acquired after $48 \mathrm{hrs}$ ): Diagnosis of infection was based on: purulent tracheal aspirate, fever $>38.5^{\circ} \mathrm{C}$, leukocytosis $>10,000 \mathrm{WBC} / \mathrm{mm}^{3}$, new and persistent infiltrate on chest X-ray

Mortality: in ICU

\section{Notes}

\section{Risk of bias}

\section{Bias}

Allocation concealment (selection bias)

\section{Authors' judgement Support for judgement}

Unclear risk B - Unclear

\section{Rocha 1992}

\begin{tabular}{|c|c|}
\hline Methods & $\begin{array}{l}\text { Randomised, placebo-controlled study } \\
\text { Blinding: double blind } \\
\text { Randomisation method: made by the Pharmacy's service according to computer generated random } \\
\text { numbers } \\
\text { Accrual period: Sept } 89 \text { to Oct } 90\end{array}$ \\
\hline \multirow[t]{2}{*}{ Participants } & $\begin{array}{l}\text { Eligibility criteria: expected mechanical ventilation for more than three days, stay in ICU more than five } \\
\text { days } \\
\text { Exclusion criteria: infection or strong suspicion of this at the start of ventilation, antibiotic treatment in } \\
\text { the previous seven days, neutropenia }\left(\mathrm{WBC}<500 / \mathrm{mm}^{3} \text { ) and fever, pregnancy, history of hypersensitivi- }\right. \\
\text { ty to the topical agents }\end{array}$ \\
\hline & $\begin{array}{l}\text { Number of patients enrolled in the study: } 151 \\
\text { Percentage of ventilated patients: } 100 \% \\
\text { Length of stay in ICU, median eight days } \\
\text { Type of admission diagnosis: medical } 28 \% \text { surgical scheduled } 3 \% \text { surgical unscheduled } 1 \% \text { trauma } \\
68 \% \\
\text { Severity score on admission: APACHE II mean }=16.3, \text { ISS not available, GCS mean = nine } \\
\text { Percentage of immunocompromised patients: } 0.7 \% \\
\text { Percentage of patients treated with systemic antibiotic therapy (not stated in the protocol) in the first } \\
\text { three days: treatment }=0 \% \text { CTR }=0 \% \\
\text { Stress ulcer prophylaxis applied: } \mathrm{H} 2 \text {-blockers and antiacids }\end{array}$ \\
\hline Interventions & $\begin{array}{l}\text { Group A, Treatment: } \\
\text { - polymyxin E } 100 \mathrm{mg} \text {, tobramycin } 80 \mathrm{mg} \text {, amphotericin B } 500 \mathrm{mg} \text { applied enterally and, as a } 2 \% \text { paste, } \\
\text { to the oropharynx four times a day } \\
\text { - cefotaxime } 6 \mathrm{~g} / \text { day iv for the first four days } \\
\text { Group B, CTR: } \\
\text { - Placebo } \\
\text { - No systemic prophylaxis }\end{array}$ \\
\hline
\end{tabular}


Rocha 1992 (Continued)

Diagnosis of infection was based on:

purulent pulmonary secretions, new infiltrates in the chest X-ray and one of the following: fever/hypothermia, leukocytosis/leukopenia, positive physical examination, drop in arterial partial oxygen pressure. Bacteriologic diagnosis, even if performed (with brush in few patients), was not essential

Mortality: in ICU

Notes

Personal contact with the main investigator provided mortality data about 50 patients who were excluded from the published paper (15 early extubations, 31 early deaths, two protocol violation, two other); these data are considered in the analysis. Data about respiratory infections in excluded patients are not available

\section{Risk of bias}

\begin{tabular}{lll}
\hline Bias & Authors' judgement & Support for judgement \\
\hline $\begin{array}{l}\text { Allocation concealment } \\
\text { (selection bias) }\end{array}$ & Unclear risk & B - Unclear \\
\hline
\end{tabular}

\section{Rodriguez-Rolda 1990}

$\begin{array}{ll}\text { Methods } & \text { Randomised, placebo-controlled, dual-center study } \\ & \text { Blinding: double blind } \\ \text { Randomisation method: odd and even numbers } \\ \text { Accrual period: Jun } 88 \text { to Dec } 88\end{array}$
Eligibility criteria: patients intubated an mechanically ventilated for more than $72 \mathrm{hrs}$
Exclusion criteria: patients whose chest X-rays was difficult to interpret, with suspected inflammatory
images during the first $72 \mathrm{hrs}$, patients ventilated for less time

Number of patients enrolled in the study: 31

Percentage of ventilated patients: $100 \%$

Length of stay in ICU, median 13.5 days

Type of admission diagnosis: medical $39 \%$ surgical scheduled $16 \%$ surgical unscheduled $3 \%$ trauma $42 \%$

Severity score on admission: APACHE II mean $=17.1$, ISS not available

Percentage of immunocompromised patients: $0 \%$

Percentage of patients treated with systemic antibiotic therapy (not stated in the protocol) in the first three days: treatment $=36 \%$ CTR $=35 \%$

Stress ulcer prophylaxis applied: sucralfate or alkaline agents plus ranitidine according to a randomised open protocol

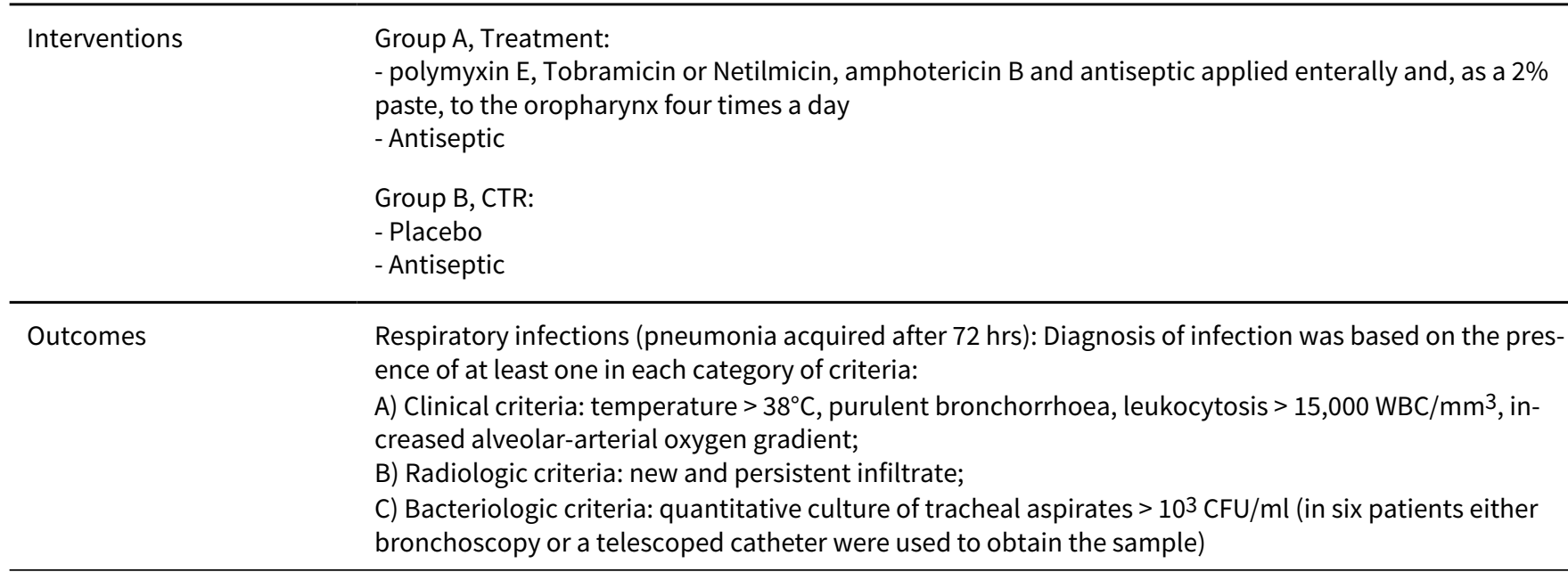


Rodriguez-Rolda 1990 (Continued)

\author{
Mortality: in ICU
}

Notes

Personal contact with the main investigator provided data about three patients who were excluded from the published paper (two early deaths, one other); these data are considered in the analysis

\title{
Risk of bias
}

Bias Authors' judgement Support for judgement

Allocation concealment
(selection bias)

\section{Sanchez-Garcia 1992}

\begin{tabular}{|c|c|}
\hline Methods & $\begin{array}{l}\text { Randomised, placebo-controlled, multicentric (five ICUs) study } \\
\text { Blinding: double blind } \\
\text { Randomisation method: sealed envelopes. } \\
\text { Accrual period: not available }\end{array}$ \\
\hline Participants & $\begin{array}{l}\text { Eligibility criteria: expected ventilation for longer than } 48 \text { hrs, age > } 16 \text { yrs } \\
\text { Exclusion criteria: death or extubation before } 48 \text { hrs, pregnancy, allergy to study antibiotics, organ } \\
\text { transplantation, absence or contraindication to nasogastric tube } \\
\text { Number of patients enrolled in the study: } 271 \\
\text { Percentage of ventilated patients: } 100 \% \\
\text { Length of stay in ICU, median } 13 \text { days } \\
\text { Type of admission diagnosis: medical } 70 \% \text { surgical scheduled } 3 \% \text { surgical unscheduled } 9 \% \text { trauma } \\
18 \% \\
\text { Severity score on admission: APACHE II mean = } 26.6 \text {, ISS not available } \\
\text { Percentage of immunocompromised patients: } 4.4 \% \\
\text { Percentage of patients treated with systemic antibiotic therapy (not stated in the protocol) in the first } \\
\text { three days: treatment = } 70 \% \text { CTR = } 69 \% \\
\text { Stress ulcer prophylaxis applied: each group was randomised to receive either sucralfate or H2-block- } \\
\text { ers }\end{array}$ \\
\hline
\end{tabular}

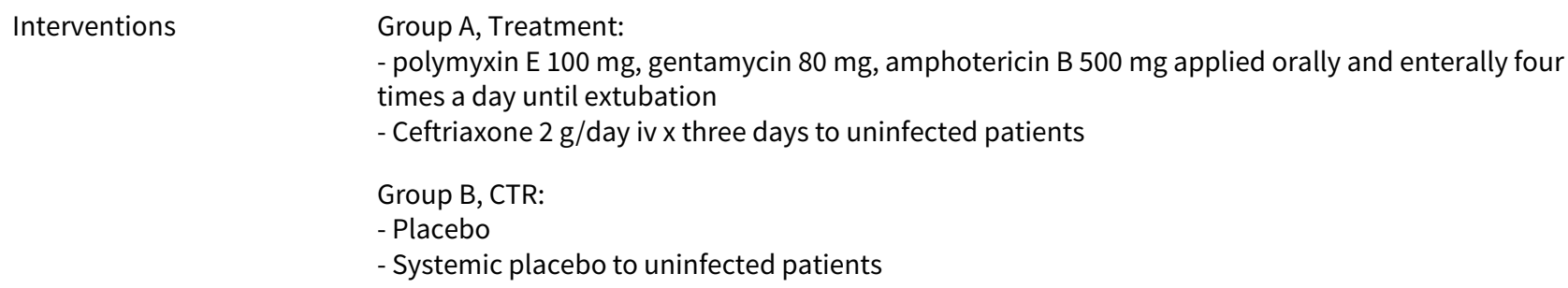

\begin{tabular}{|c|c|}
\hline Outcomes & $\begin{array}{l}\text { Respiratory infections (early and late acquired pneumonia): } \\
\text { Diagnosis of infection was based on: } \\
\text { new and persistent infiltrate on chest X-ray and three of the following: temperature }>38.5^{\circ} \mathrm{C}, \text { leukocyto- } \\
\text { sis }>12,000 \mathrm{WBC} / \mathrm{mm}^{3} \text { or leukopenia }<3,000 \mathrm{WBC} / \mathrm{mm}^{3} \text {, purulent tracheal aspirate with growth of a po- } \\
\text { tentially pathogenic micro-organism }\end{array}$ \\
\hline & Mortality: in ICU \\
\hline Notes & $\begin{array}{l}\text { Personal contact with the main investigator provided data about } 45 \text { patients who were excluded from } \\
\text { the published paper ( } 12 \text { early extubations, } 12 \text { early deaths, } 17 \text { protocol violation, two transferring, two } \\
\text { other); these data are considered in the analysis }\end{array}$ \\
\hline
\end{tabular}

\section{Risk of bias}


Sanchez-Garcia 1992 (Continued)

\begin{tabular}{lll} 
Bias & Authors' judgement & Support for judgement \\
\hline $\begin{array}{l}\text { Allocation concealment } \\
\text { (selection bias) }\end{array}$ & Low risk & A - Adequate \\
\hline
\end{tabular}

\section{Stoutenbeek 1996}

\begin{tabular}{ll}
\hline Methods & Randomised, placebo-controlled study \\
& Blinding: double blind. \\
& Randomisation method: closed envelope method (the code was known by the pharmacist only). \\
& Accrual period: Nov 84 to Aug 86
\end{tabular}

\section{Participants}

Eligibility criteria: all patients admitted to the surgical ICU with blunt trauma and an HTI-ISS > 18, age > 18 yrs

Exclusion criteria: patients mechanically ventilated for less than five days or discharged from ICU within seven days and with an HTI-ISS $<18$ after $24 \mathrm{hrs}$

Number of patients enrolled in the study: 91

Percentage of ventilated patients: $100 \%$

Length of stay in ICU, mean $=15$ days

Type of admission diagnosis: trauma $100 \%$

Severity score on admission: APACHE II mean $=10.6, \mathrm{HTI}-\mathrm{ISS}$ mean $=35.1$

Percentage of immunocompromised patients: $0 \%$

Percentage of patients treated with systemic antibiotic therapy (not stated in the protocol) in the first three days: treatment $=0 \% \mathrm{CTR}=0 \%$

Stress ulcer prophylaxis applied: none except for patients with history of preexisting ulcer or on $\mathrm{H} 2$ blockers

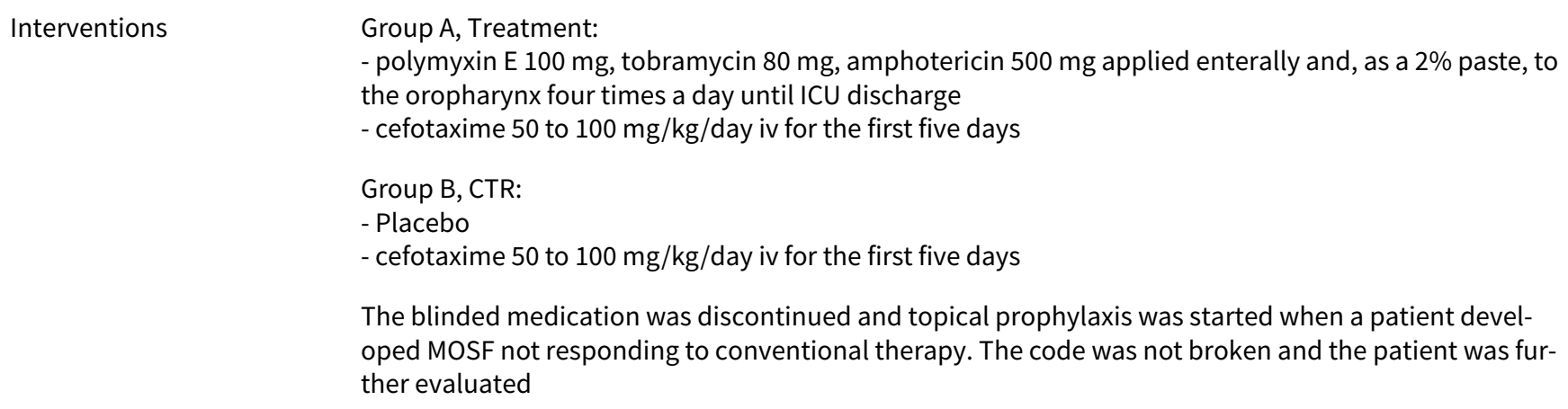

The blinded medication was discontinued and topical prophylaxis was started when a patient developed MOSF not responding to conventional therapy. The code was not broken and the patient was further evaluated

\begin{tabular}{|c|c|c|}
\hline Outcomes & \multicolumn{2}{|c|}{$\begin{array}{l}\text { Respiratory infections (tracheobronchitis and pneumonia - early and late infections) } \\
\text { Diagnosis of infection was based on clinical criteria: temperature }>38.5^{\circ} \mathrm{C}, \mathrm{WBC}>12.5 \times 10^{9} / \mathrm{l} \text { or } \\
\text { leukopenia }<4 \times 10^{\wedge} 9 / \mathrm{l} \text {, purulent secretions or X-ray changes and significant growth of bacteria } \\
\text { Mortality: in ICU }\end{array}$} \\
\hline Notes & \multicolumn{2}{|c|}{$\begin{array}{l}\text { Data about } 32 \text { patients who were initially excluded ( } 25 \text { early extubations, four early deaths, three other) } \\
\text { are considered in the analysis }\end{array}$} \\
\hline \multicolumn{3}{|l|}{ Risk of bias } \\
\hline Bias & Authors' judgement & Support for judgement \\
\hline $\begin{array}{l}\text { Allocation concealment } \\
\text { (selection bias) }\end{array}$ & Low risk & A - Adequate \\
\hline
\end{tabular}




\begin{tabular}{|c|c|}
\hline Methods & $\begin{array}{l}\text { Randomised, multicenter study. Intention to treat } \\
\text { Blinding: open } \\
\text { Randomisation method: randomisation lists prepared by the Biometrical Department and supplied } \\
\text { with sealed envelopes } \\
\text { Accrual period: Oct } 91 \text { to Jun } 94\end{array}$ \\
\hline Participants & $\begin{array}{l}\text { Eligibility criteria: patients admitted within } 24 \text { hrs after nonpenetrating blunt trauma with an HTI-ISS >= } \\
\text { 16, necessitating mechanical ventilation, age }>18 \text { yrs } \\
\text { Exclusion criteria: previous antibiotic use for more than three days at study entry, allergy to cefotaxime, } \\
\text { referred patients from other hospital or secondary admissions with trauma occurred }>24 \text { hrs before } \\
\text { Number of patients enrolled in the study: } 405 \text {, but } 401 \text { patients were analysed } \\
\text { Percentage of ventilated patients: } 100 \% \\
\text { Median length of ICU stay: SDD = } 13 \text { days, CTR }=12 \text { days } \\
\text { Median duration of mechanical ventilation: SDD = nine days, CTR = eight days } \\
\text { Type of admission diagnosis: trauma } 100 \% \\
\text { Severity score on admission - APACHE II median: SDD = } 15, \text { CTR = } 14 \text { and HTI-ISS median: SDD = 34, CTR } \\
=29 \\
\text { Percentage of immunocompromised patients: } 0 \% \\
\text { Percentage of patients treated with systemic antibiotic therapy (not stated in the protocol) in the first } \\
\text { three days: treatment }=46 \% \text { CTR }=88 \% \\
\text { Stress ulcer prophylaxis applied: sucralfate, H2-blockers, omeprazole; no sucralfate }\end{array}$ \\
\hline
\end{tabular}

$\begin{array}{ll}\text { Interventions } & \text { Group A, Treatment: } \\ \text { - polymyxin E, tobramycin, amphotericin B administered through the nasogastric tube and applied to } \\ \text { the buccal mucosa four times a day until discharge } \\ \text { - cefotaxime } 1 \text { g every six hours for four days } \\ \text { Group B, CTR: } \\ \text { - Standard antibiotic prophylaxis used in each centres (no fluoroquinolones) }\end{array}$

Outcomes

Primary: Mortality from infection or multiple organ failure in ICU or up to two weeks after discharge

Secondary: incidence of infection, multiple organ failure and antibiotic usage

The maximum observation period was three months

Patients dying within 24 hours after injury or dying from craniocerebral trauma were excluded

Diagnosis of pneumonia was based on any of the following: presence of a new and progressive pulmonary infiltrate on chest X-ray for $>=48 \mathrm{hrs}$, purulent tracheal aspirate, fever $>38.5^{\circ} \mathrm{C}$, leukocytosis $>$ $12,000 / \mathrm{ml}$ or leukopenia $<4000 / \mathrm{ml}$

Diagnosis of tracheobronchitis was based on the same criteria except for the radiographic changes Mortality: in ICU or up to two weeks after discharge

Notes four patients were excluded from the final analysis after randomisation: two because they did not fulfil the inclusion criteria, the data for one patient were not available and one was lost to follow-up after the 7 th day

\section{Risk of bias}

\begin{tabular}{lll}
\hline Bias & Authors' judgement & Support for judgement \\
\hline $\begin{array}{l}\text { Allocation concealment } \\
\text { (selection bias) }\end{array}$ & Low risk & A-Adequate \\
\hline
\end{tabular}


Ulrich 1989

\begin{tabular}{ll}
\hline Methods & Randomised, placebo-controlled study \\
& Blinding: open \\
& Randomisation method: sealed envelopes containing a random code for clusters of four patients \\
& Accrual period: Oct 86 to Sep 87 \\
\hline Participants & Eligibility criteria: patients expected to stay in the ICU more than five days and ventilated more than 48 \\
hrs & Exclusion criteria: patients who died within 24 hrs after randomisation \\
& Number of patients enrolled in the study: 112 \\
& Percentage of ventilated patients: about $80 \%$ \\
& Length of stay in ICU, median $=10$ days \\
& Type of admission diagnosis: medical $34 \%$ surgical scheduled $19 \%$ surgical unscheduled $31 \%$ trauma \\
& $16 \%$ \\
& Severity score on admission: SAPS mean $=11.7$, ISS mean $=36.9$ \\
& Percentage of immunocompromised patients: $3 \%$ \\
Percentage of patients treated with systemic antibiotic therapy (not stated in the protocol) in the first \\
three days: treatment = $83 \%$ CTR = $81 \%$ \\
Stress ulcer prophylaxis applied: not available \\
Group A,Treatment: \\
- polymyxin E 100 mg, norfloxacin 50 mg, amphotericin B 500 mg, applied enterally and, as a $2 \%$ paste, \\
to the oropharynx four times a day \\
- Trimethoprim 500 mg iv \\
Group B, CTR: \\
- Placebo
\end{tabular}

Outcomes Respiratory infections (acquired pneumonia):

Diagnosis of infection was based on clinical and radiologic signs of pulmonary infiltrations with fever and leukocytosis and a dense growth in cultures of sputum of tracheal aspirate

Mortality: in ICU

Notes Personal contact with the main investigator provided data about 12 patients who were excluded from the published paper (early death); these data are considered in the analysis

\section{Risk of bias}

\begin{tabular}{lll}
\hline Bias & Authors' judgement & Support for judgement \\
\hline $\begin{array}{l}\text { Allocation concealment } \\
\text { (selection bias) }\end{array}$ & Low risk & A - Adequate \\
\hline
\end{tabular}

\section{Unertl 1987}

\begin{tabular}{ll}
\hline Methods & $\begin{array}{l}\text { Randomised study } \\
\text { Blinding: outcome assessor } \\
\text { Randomisation method: blocked randomisation scheme and the sealed envelope technique. Blind } \\
\text { Accrual period: May } 84 \text { to Jan } 85\end{array}$ \\
\hline Participants & $\begin{array}{l}\text { Eligibility criteria: all patients admitted to the ICU with: intubation within } 24 \text { hrs after the onset of an } \\
\text { acute disease or surgery, expected ventilation }>\text { six days, interval between intubation and first microbi- } \\
\text { ologic culture < } 36 \text { hrs } \\
\text { Exclusion criteria: Patients with infection, systemic antibiotic treatment, respiratory distress syndrome, } \\
\text { leucopenia and myelosuppression on admission, renal failure }\end{array}$
\end{tabular}


Unertl 1987 (Continued)

Number of patients enrolled in the study: 39

Percentage of ventilated patients: $100 \%$

Length of stay in ICU: not available

Type of admission diagnosis: medical 52\%, surgical 15\%, trauma 33\%

Severity score on admission: SAPS mean $=12.5$, GCS $(75 \%$ of patients have GCS $<7)$

Percentage of immunocompromised patients: not available

Percentage of patients treated with systemic antibiotic therapy (not stated in the protocol) in the first

three days: not available

Stress ulcer prophylaxis applied: $\mathrm{H} 2$-blockers to all patients and antiacids if $\mathrm{pH}<4$

\begin{tabular}{|c|c|c|}
\hline Interventions & \multicolumn{2}{|c|}{$\begin{array}{l}\text { Group A, Treatment: } \\
\text { - polymyxin B } 50 \mathrm{mg} \text {, gentamycin } 80 \mathrm{mg} \text {, applied orally, nasally and enterally four times a day until ex- } \\
\text { tubation } \\
\text { - Amphoterycin B } 300 \mathrm{mg} \text { applied orally four times a day } \\
\text { Group B, CTR: } \\
\text { - No prophylaxis }\end{array}$} \\
\hline Outcomes & \multicolumn{2}{|c|}{$\begin{array}{l}\text { Respiratory infections (acquired pneumonia): } \\
\text { Diagnosis of infection was based on: } \\
\text { new 'definite' infiltrate on chest X-ray together with increasing amounts of purulent tracheobronchial } \\
\text { secretion containing }>3 \times 10^{4} \text { granulocytes } / \mathrm{mcl} \text { and at least two of the following: new febrile spikes }> \\
38.5^{\circ} \mathrm{C} \text {, blood leukocyte count }>12000 / \mathrm{mcl} \text { or }<4000 / \mathrm{mcl} \text {, decrease of } \mathrm{PaO}_{2} \text { requiring an increase of the } \\
\mathrm{FiO}_{2} \text { of at least } 15 \% \text { to maintain oxygen tension. } \\
\text { 'Definite' is an infiltrate confirmed by two blind independent radiologists and not reversible after chest } \\
\text { physiotherapy } \\
\text { Mortality: in ICU }\end{array}$} \\
\hline \multicolumn{3}{|l|}{ Notes } \\
\hline \multicolumn{3}{|l|}{ Risk of bias } \\
\hline Bias & Authors' judgement & Support for judgement \\
\hline $\begin{array}{l}\text { Allocation concealment } \\
\text { (selection bias) }\end{array}$ & Low risk & A - Adequate \\
\hline
\end{tabular}

\section{Verwaest 1997}

\section{Methods}

Randomised study with three arms (one control arm and two treatment arms)

Blinding: open

Randomisation method: sealed envelopes with computer generated random numbers

Accrual period: Sept 89 to Mar 91
Eligibility criteria: expected ventilation $>48$ hrs

Exclusion criteria: age $<18$ yrs, pregnancy, recent organ transplantation, serious granulocytopenia $(<=$ $500 \mathrm{WBC} / \mathrm{mm}^{3}$ ), ventilation $<48 \mathrm{hrs}$, death before $48 \mathrm{hrs}$, missing of essential data in the clinical or bacteriological dossier

Number of patients enrolled in the study: 660 (only two groups of patients, A and B, are considered in this comparison, totaling 440 patients)

Percentage of ventilated patients: $100 \%$

Length of stay in ICU, mean $=19.6$ days

Type of admission diagnosis: medical $10 \%$, surgical $67 \%$ trauma $23 \%$

Severity score on admission: APACHE II mean = 18.1, ISS not available

Percentage of immunocompromised patients: not available 
Verwaest 1997 (Continued)

Percentage of patients treated with systemic antibiotic therapy (not stated in the protocol) in the first three days: treatment one $=34 \%$ treatment twp $=31 \%$ CTR $=34 \%$

Stress ulcer prophylaxis applied: sucralfate $2 \mathrm{~g} \times 4$

\begin{tabular}{ll}
\hline Interventions & Group A, CTR: \\
& - No prophylaxis, antibiotic therapy was used only if an infection was suspected \\
& Group B, Treatment 1: \\
& - Ofloxacin $200 \mathrm{mg} \times 2$, Amphoterycin B $500 \mathrm{mg} \times 4$ applied enterally and, as a $2 \%$ paste, to the orophar- \\
& ynx four times a day until discharge \\
- Ofloxacin $200 \mathrm{mg}$ iv $x$ four days
\end{tabular}

\begin{tabular}{ll}
\hline Outcomes & $\begin{array}{l}\text { Respiratory infections (pneumonia acquired after } 48 \mathrm{hrs} \text { ): } \\
\text { Diagnosis of infection was based on: } \\
\text { Fever }>38.5^{\circ} \mathrm{C} \text {, leukocytosis }>10,000 \text { cells/mcl, luxuriant growth of potentially pathogenic micro-organ- } \\
\text { isms in culture of bronchial aspirate, new and persistent infiltrate on chest X-ray } \\
\text { Mortality: in ICU }\end{array}$ \\
\hline Notes & $\begin{array}{l}\text { Personal contact with the main investigator provided mortality data about } 82 \text { patients who were ex- } \\
\text { cluded ( } 33 \text { early deaths, } 49 \text { other); these data are considered in the analysis.Data about respiratory in- } \\
\text { fections in excluded patients are not available }\end{array}$
\end{tabular}

\section{Risk of bias}

\begin{tabular}{lll}
\hline Bias & Authors' judgement & Support for judgement \\
\hline $\begin{array}{l}\text { Allocation concealment } \\
\text { (selection bias) }\end{array}$ & Low risk & A - Adequate \\
\hline
\end{tabular}

Wiener 1995

$\begin{array}{ll}\text { Methods } & \text { Randomised, placebo-controlled study } \\ \text { Blinding: double blind } \\ \text { Randomisation method: random number table in blocks of six patients } \\ \text { Accrual period: eight months }\end{array}$
Participants Eligibility criteria: expected intubation for more than $48 \mathrm{hrs}$, inclusion within 18 hrs of intubation, age > 18 yrs Exclusion criteria: refusal to consent, allergy to one of the components of the regimen, active inflam- matory bowel disease
Patients enrolled in the study: 121, but 60 patients were excluded leaving 61 patients for analysis Percentage of ventilated patients: $100 \%$ Length of stay in ICU, mean: 11.3 days
Type of admission diagnosis: not available Severity score on admission: APACHE II mean $=27.2$, ISS not available
Percentage of immunocompromised patients: > 5\%
Percentage of patients treated with systemic antibiotic therapy (not stated in the protocol) in the first three days: treatment $=93 \% \mathrm{CTR}=81 \%$ Stress ulcer prophylaxis applied: $\mathrm{H} 2$-blockers to most patients

Group A, Treatment:
- polymyxin E $100 \mathrm{mg}$, gentamycin $80 \mathrm{mg}$, nystatin 2,000,000 UI applied enterally four times a day and,
as a $2 \%$ paste, to the oropharynx until extubation or tracheostomy
Group B, CTR:


Wiener 1995 (Continued)

$$
\text { - Placebo }
$$

Outcomes Respiratory infections (pneumonia acquired after $48 \mathrm{hrs}$ ):

Diagnosis of infection was based on the presence of the following: persistence of a new or progressive infiltrate on chest-film, fever $>38.5^{\circ} \mathrm{C}$ and/or leukocytosis $>12,000 / \mathrm{mm}^{3}$, growth of $>10^{3}$ bacteria from a quantitative culture of lower respiratory tract secretions obtained with a blind protected catheter

Mortality: in ICU

Notes

60 patients were excluded after randomisation; data are not available

\section{Risk of bias}

\begin{tabular}{lll}
\hline Bias & Authors' judgement & Support for judgement \\
\hline $\begin{array}{l}\text { Allocation concealment } \\
\text { (selection bias) }\end{array}$ & Unclear risk & B - Unclear \\
\hline
\end{tabular}

Winter 1992

\begin{tabular}{ll}
\hline Methods & Randomised study \\
& Blinding: open. \\
& Randomisation method: sealed envelopes based on a computer generated table of random numbers. \\
& Accrual period: Jul 88 to May 90
\end{tabular}

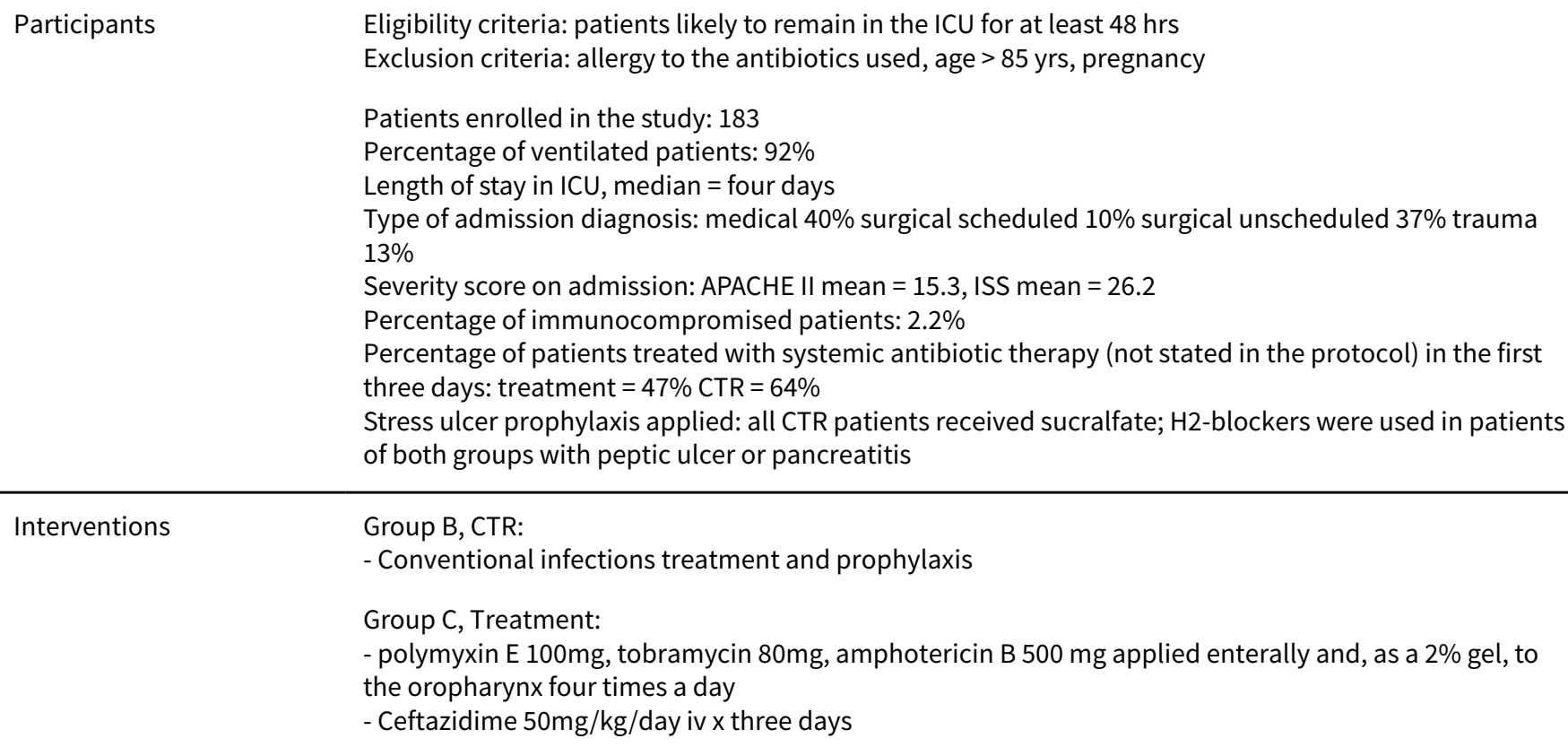

Outcomes

Respiratory infections (pneumonia acquired after $48 \mathrm{hrs}$ ): Diagnosis of infection was based on: temperature $>38.5^{\circ} \mathrm{C}$ two times in $24 \mathrm{hrs}$, WBC < 4 or $>12 \times 109 /$, positive BAL, two of the following: new pulmonary infiltrates on chest $\mathrm{X}$-ray, purulent sputum, increase of $15 \%$ in $\mathrm{FiO}_{2}$ to maintain previous oxygenation

Mortality: in hospital

Notes Few patients were excluded after randomisation; data are not available


Winter 1992 (Continued)

Risk of bias

\begin{tabular}{lll}
\hline Bias & Authors' judgement & Support for judgement \\
\hline $\begin{array}{l}\text { Allocation concealment } \\
\text { (selection bias) }\end{array}$ & Low risk & A - Adequate \\
\hline
\end{tabular}

APACHE Acute Physiology and Chronic Health Evaluation

ARDS Acute Respiratory Distress Syndrome

BAL Broncho-Alveolar-Lavage

CCU Coronary Care Unit

CDC Centre for Disease Control

CFU Colony Forming Unit

$\mathrm{Cl}$ Confidence Interval

CTR Control group

GCS Glasgow Coma Score

hrs hours

HTI-ISS Hospital Trauma Index-Injury Severity Score

ICU Intensive Care Unit

ISS Injury Severity Score

iv intravenous

MOSF Multi-Organ-System-Failure

OR Odds Ratio

RCTs Randomised Controlled Trials

RD Risk Differences

RR Relative Risk

RTIs Respiratory Tract Infections

SAPS Symplified Acute Physiology Score

SDD Selective Decontamination of the Digestive Tract

VAP Ventilator Associated Pneumonia

VO2 Oxygen Consumption

yrs years

WBC White Blood Count

Characteristics of excluded studies [ordered by study ID]

\begin{tabular}{ll}
\hline Study & Reason for exclusion \\
\hline Arnow 1996 & The study included a selected population of patients undergoing liver transplant \\
\hline Barret 2001 & The study included only paediatric burns patients \\
\hline Bion 1994 & The study included a selected population of patients undergoing liver transplant \\
\hline Bouter 2002 & The study included only patients undergoing cardiopulmonary by-pass \\
\hline de la Cal 2005 & The study included only critically ill burns patients \\
\hline de Smet 2009 & $\begin{array}{l}\text { The study adopted a cluster design with type of treatments alternated for specific periods of time } \\
\text { across participating hospitals. As a consequence patients were not properly randomised and the } \\
\text { study could be affected by selection bias. }\end{array}$ \\
\hline Flaherty 1990 & The study included a selected population of cardio surgical patients \\
\hline Garbino 2002 & The study tested the effectiveness of fluconazole as both groups received SDD \\
\hline
\end{tabular}




\begin{tabular}{|c|c|}
\hline Study & Reason for exclusion \\
\hline Hellinger 2002 & The study included only liver transplant patients \\
\hline Hunefeld 1989 & After contacting the principal investigator it become apparent that it was not a randomised study \\
\hline Jacobs 1995 & $\begin{array}{l}\text { This study, included in the previous version of this review as a personal contact with the principal } \\
\text { investigator, has been excluded due to lack of feedback from the trial author. To date, this study } \\
\text { has never been published }\end{array}$ \\
\hline Lenhart 1994 & $\begin{array}{l}\text { This study, included in the previous version of this review as a congress proceeding, has been re- } \\
\text { placed by its published article (Krueger 2002) }\end{array}$ \\
\hline Lipman 1994 & After contacting the principal investigator it become apparent that it was not a randomised study \\
\hline Luiten 1995 & $\begin{array}{l}\text { The study included a selected population of patients affected by pancreatitis characterised by a } \\
\text { low percentage of ICU admissions. }\end{array}$ \\
\hline Martinez 1994 & The study compared the effect of two different prophylactic regimens without a control group \\
\hline Martinez-Pellus 1993 & The study included a selected population of cardio surgical patients \\
\hline Nardi 2001 & The study tested the effectiveness of mupirocin as both groups received SDD \\
\hline Rayes 2002 & The study included only liver transplant patients \\
\hline Rolando 1996 & The study included a selected population of patients with acute hepatic failure \\
\hline Ruza 1998 & The study included only paediatric burns patients \\
\hline Schardey 1997 & $\begin{array}{l}\text { The study included a selected population of patients undergoing gastric surgery and characterised } \\
\text { by a low percentage of ICU admission }\end{array}$ \\
\hline Smith 1993 & The study included only paediatric, liver transplant patients \\
\hline Stoutenbeek 2 & $\begin{array}{l}\text { This unpublished study, included in the previous version of this review, has been replaced by its } \\
\text { published article (Stoutenbeek 2007) }\end{array}$ \\
\hline Tetteroo 1990 & $\begin{array}{l}\text { The study included a selected population of patients undergoing oesophageal resection and char- } \\
\text { acterised by a short length of stay in ICU }\end{array}$ \\
\hline Zobel 1991 & The study included only paediatric patients \\
\hline Zwaveling 2002 & The study included only liver transplant patients \\
\hline
\end{tabular}

\section{DATA AND ANALYSES}


Comparison 1. Topical plus systemic versus no prophylaxis

\begin{tabular}{|c|c|c|c|c|}
\hline Outcome or subgroup title & $\begin{array}{l}\text { No. of } \\
\text { studies }\end{array}$ & $\begin{array}{l}\text { No. of } \\
\text { partici- } \\
\text { pants }\end{array}$ & Statistical method & Effect size \\
\hline 1 Overall mortality & 17 & 4075 & Odds Ratio (M-H, Fixed, 95\% Cl) & $0.75[0.65,0.87]$ \\
\hline $\begin{array}{l}2 \text { Mortality according to quality of al- } \\
\text { location concealment }\end{array}$ & 17 & 4075 & Odds Ratio (M-H, Fixed, 95\% Cl) & $0.75[0.65,0.87]$ \\
\hline 2.1 Adequate & 10 & 3336 & Odds Ratio (M-H, Fixed, 95\% Cl) & $0.77[0.66,0.90]$ \\
\hline 2.2 Not adequate & 7 & 739 & Odds Ratio (M-H, Fixed, 95\% Cl) & $0.67[0.48,0.93]$ \\
\hline $\begin{array}{l}3 \text { Mortality according to blinding of } \\
\text { the studies }\end{array}$ & 17 & 4075 & Odds Ratio (M-H, Fixed, 95\% CI) & $0.75[0.65,0.87]$ \\
\hline 3.1 Double-blind & 4 & 1013 & Odds Ratio (M-H, Fixed, 95\% Cl) & $0.63[0.48,0.83]$ \\
\hline 3.2 Open & 13 & 3062 & Odds Ratio (M-H, Fixed, 95\% Cl) & $0.80[0.68,0.95]$ \\
\hline 4 RTIS & 16 & 3024 & Odds Ratio (M-H, Random, 95\% Cl) & $0.28[0.20,0.38]$ \\
\hline $\begin{array}{l}5 \text { RTIs according to quality of alloca- } \\
\text { tion concealment }\end{array}$ & 16 & 3024 & Odds Ratio (M-H, Random, $95 \% \mathrm{Cl}$ ) & $0.28[0.20,0.38]$ \\
\hline 5.1 Adequate & 9 & 2335 & Odds Ratio (M-H, Random, 95\% Cl) & $0.36[0.27,0.47]$ \\
\hline 5.2 Not adequate & 7 & 689 & Odds Ratio (M-H, Random, 95\% Cl) & $0.19[0.10,0.37]$ \\
\hline $\begin{array}{l}6 \text { RTIs according to blinding of the } \\
\text { studies }\end{array}$ & 16 & 3024 & Odds Ratio (M-H, Random, $95 \% \mathrm{Cl}$ ) & $0.28[0.20,0.38]$ \\
\hline 6.1 Double-blind & 4 & 963 & Odds Ratio (M-H, Random, 95\% Cl) & $0.40[0.30,0.53]$ \\
\hline 6.2 Open & 12 & 2061 & Odds Ratio (M-H, Random, 95\% Cl) & $0.22[0.14,0.34]$ \\
\hline
\end{tabular}

\section{Analysis 1.1. Comparison 1 Topical plus systemic versus no prophylaxis, Outcome 1 Overall mortality.}

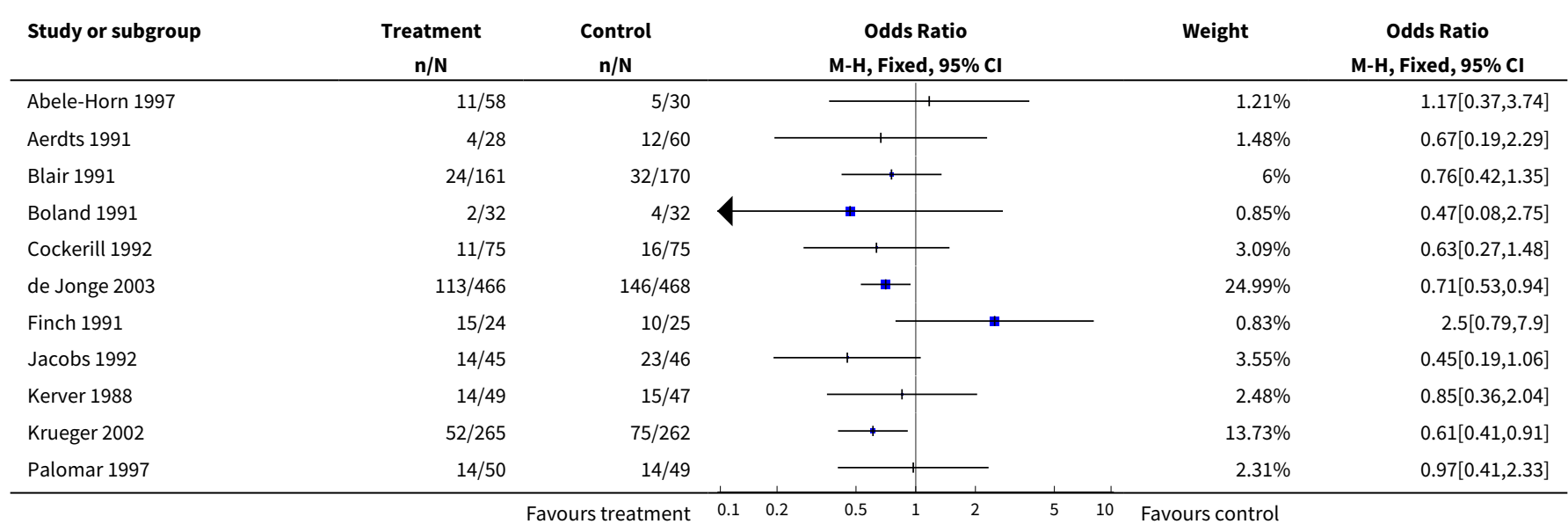




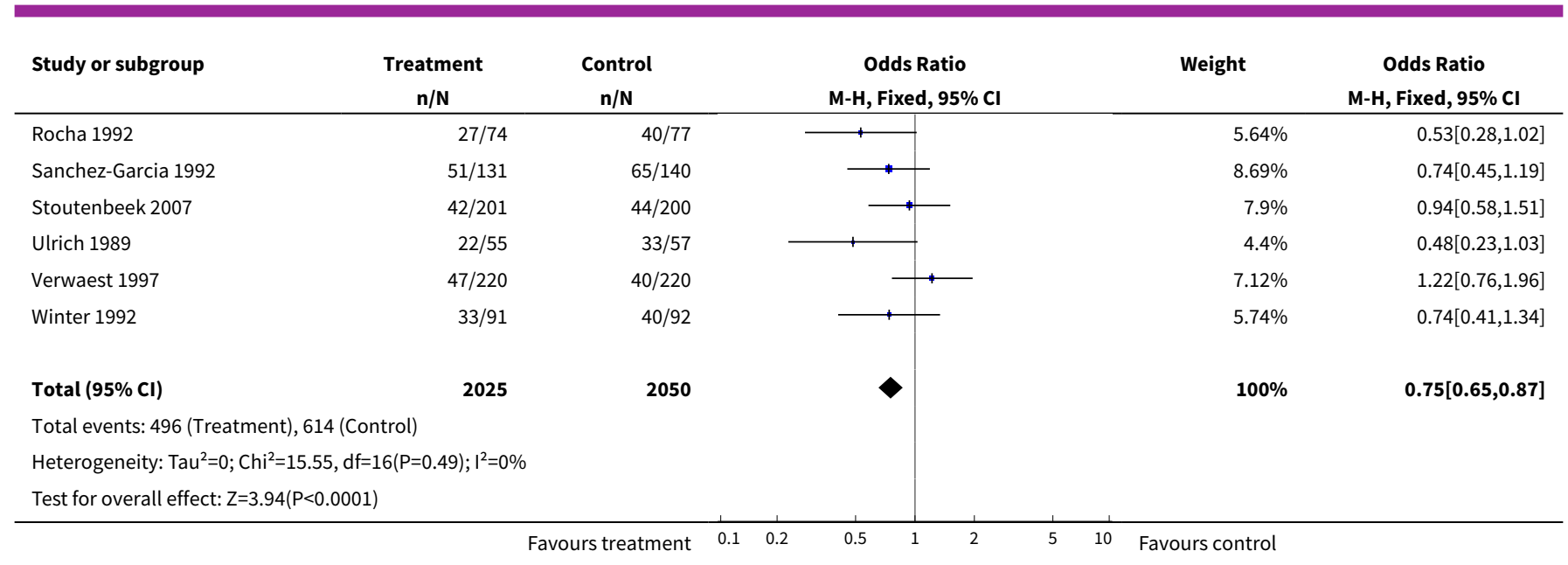

Analysis 1.2. Comparison 1 Topical plus systemic versus no prophylaxis, Outcome 2 Mortality according to quality of allocation concealment.

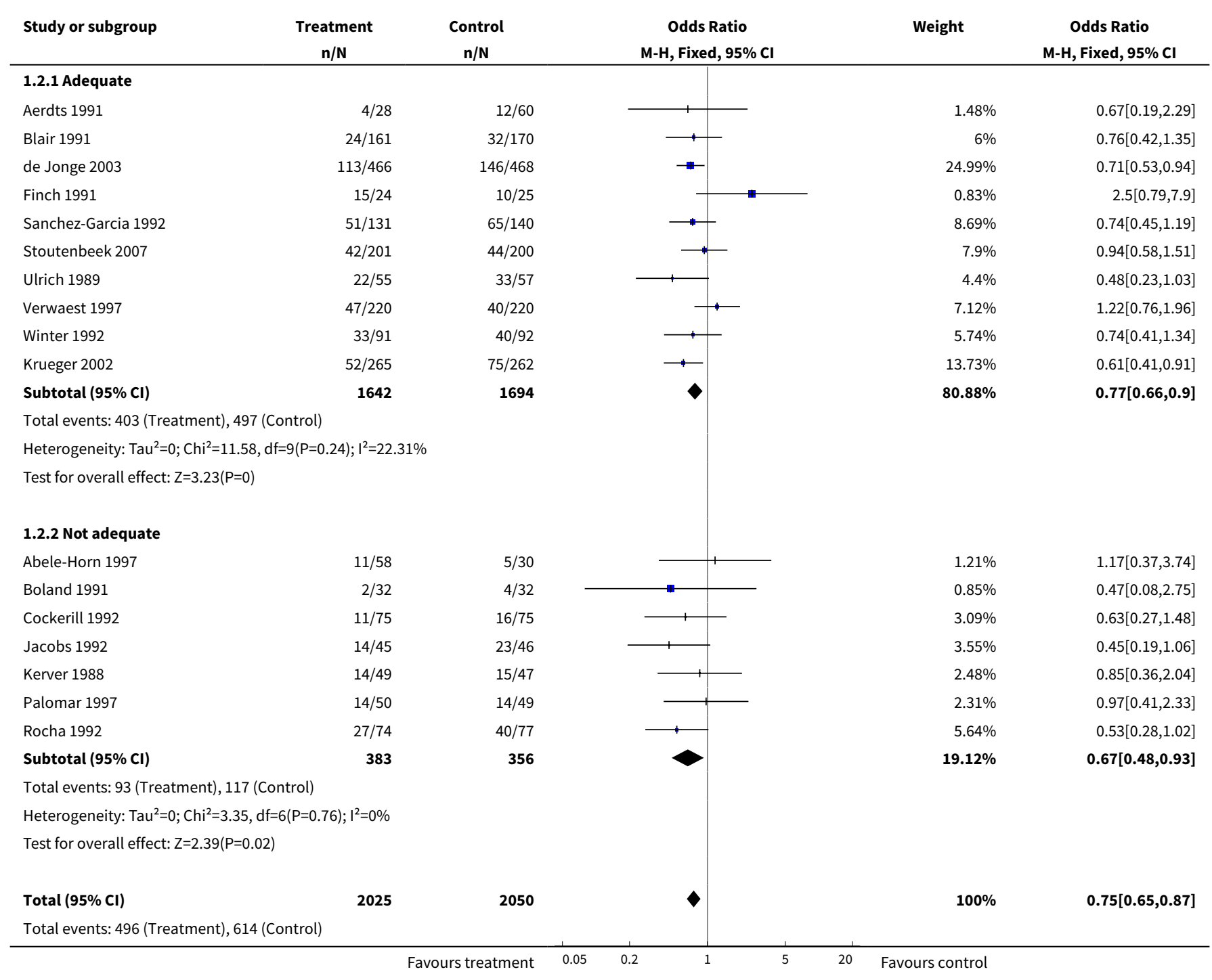




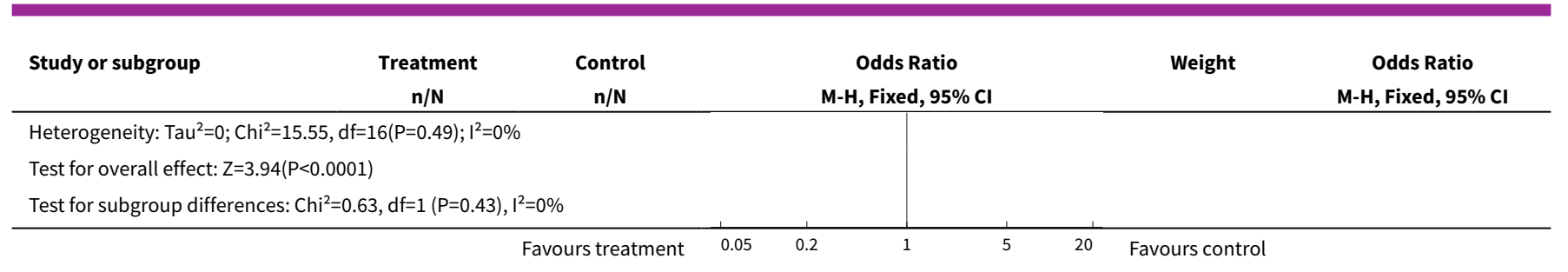

Analysis 1.3. Comparison 1 Topical plus systemic versus no prophylaxis, Outcome 3 Mortality according to blinding of the studies.

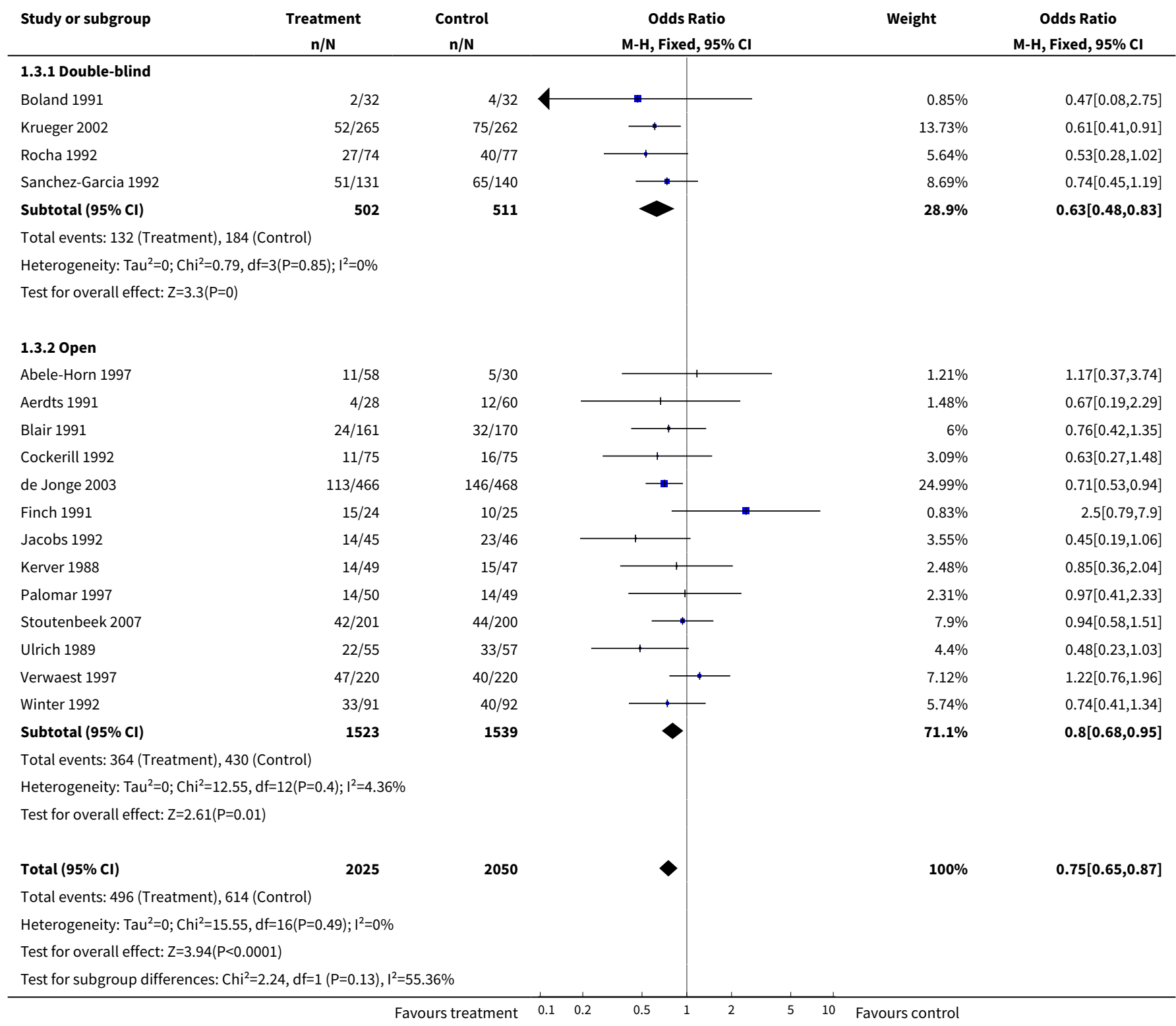


Analysis 1.4. Comparison 1 Topical plus systemic versus no prophylaxis, Outcome 4 RTIs.

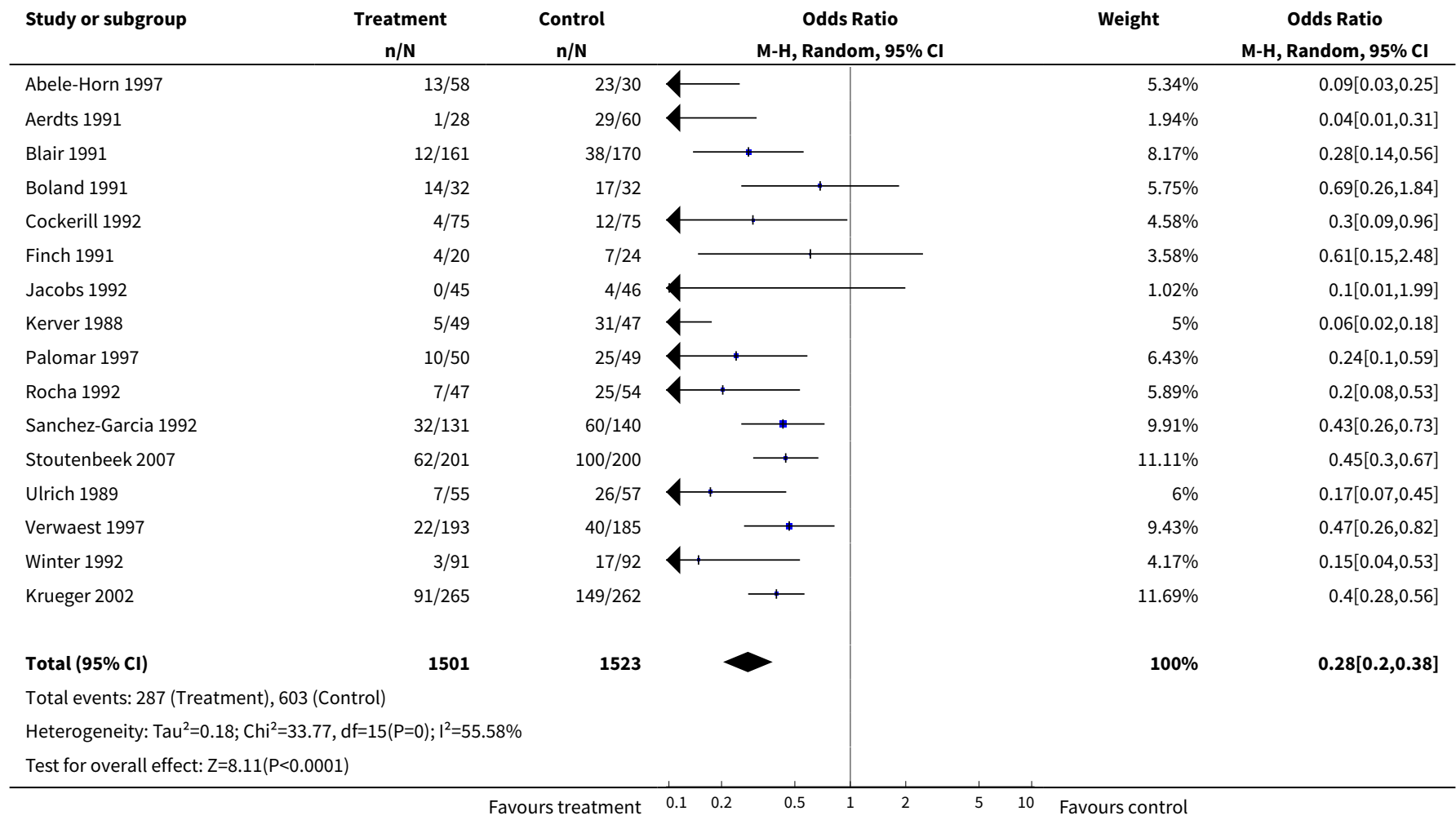

Analysis 1.5. Comparison 1 Topical plus systemic versus no prophylaxis, Outcome 5 RTIs according to quality of allocation concealment.

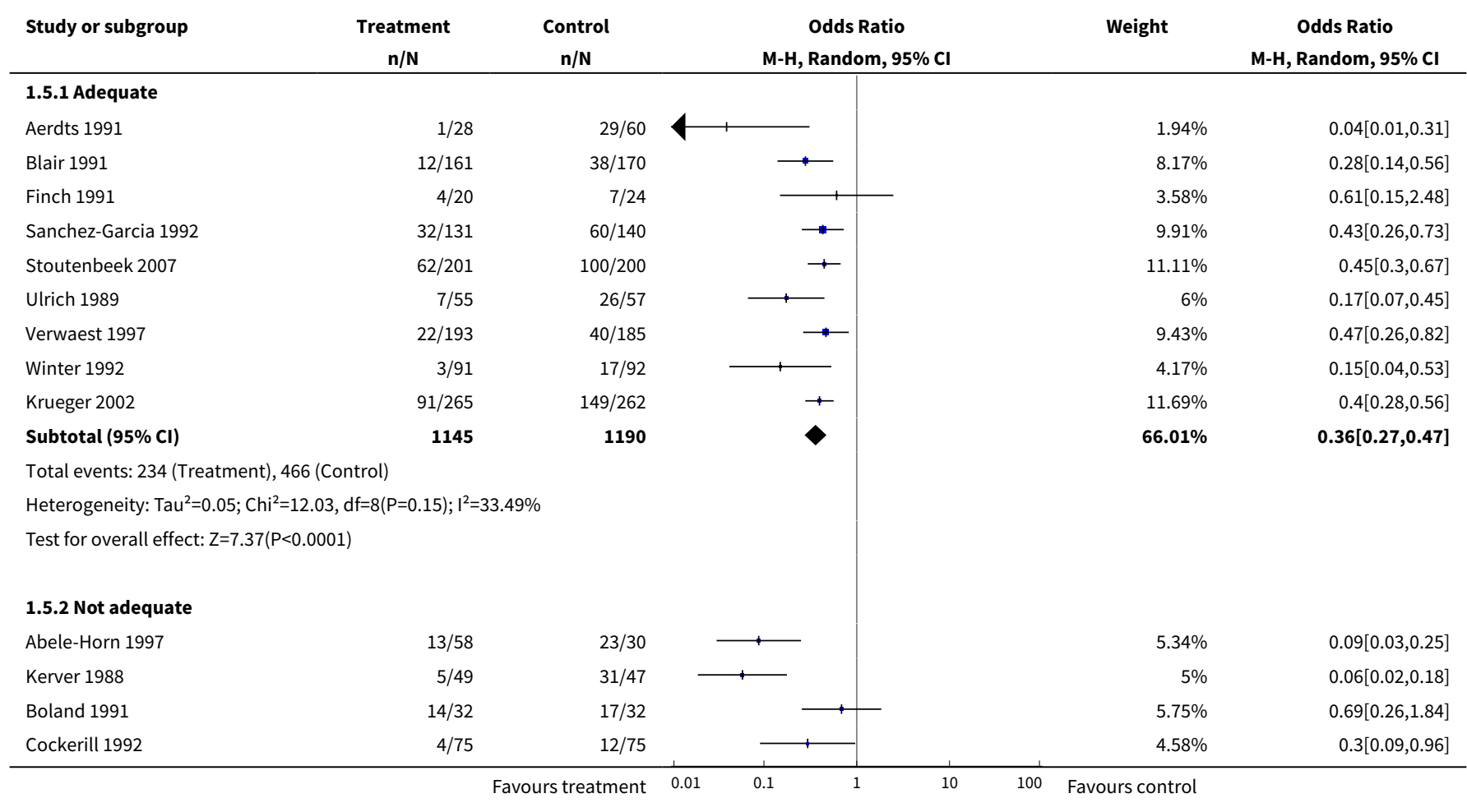




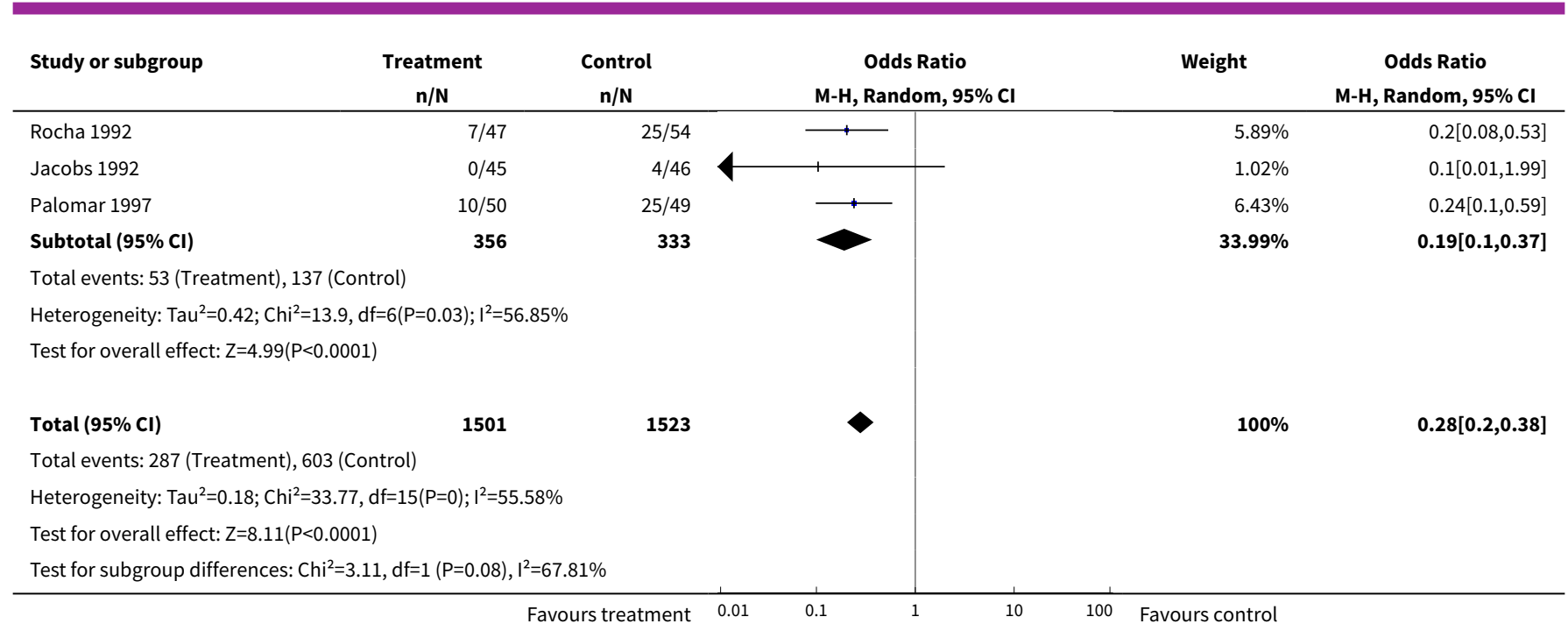

Analysis 1.6. Comparison 1 Topical plus systemic versus no prophylaxis, Outcome 6 RTIs according to blinding of the studies.

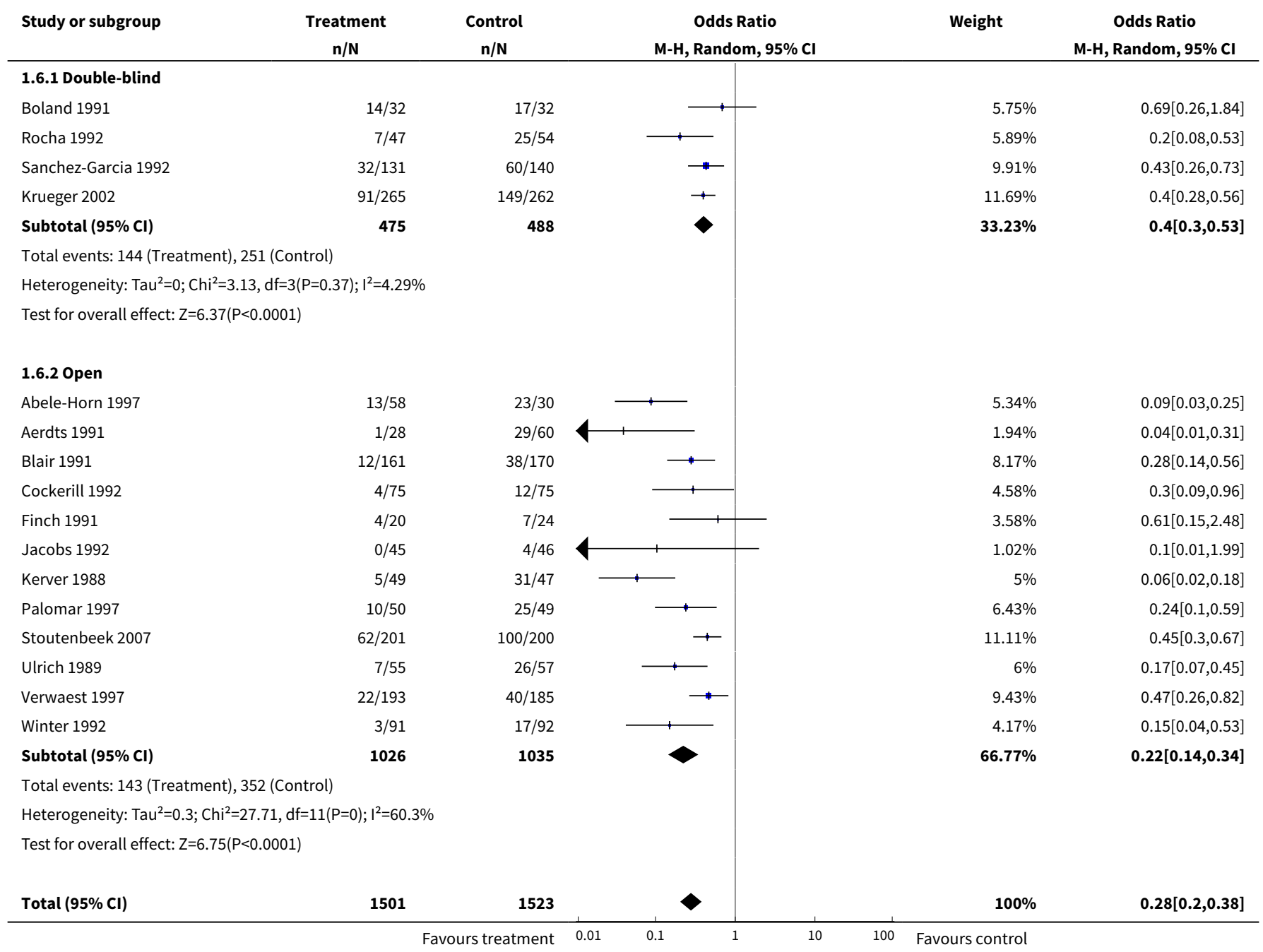




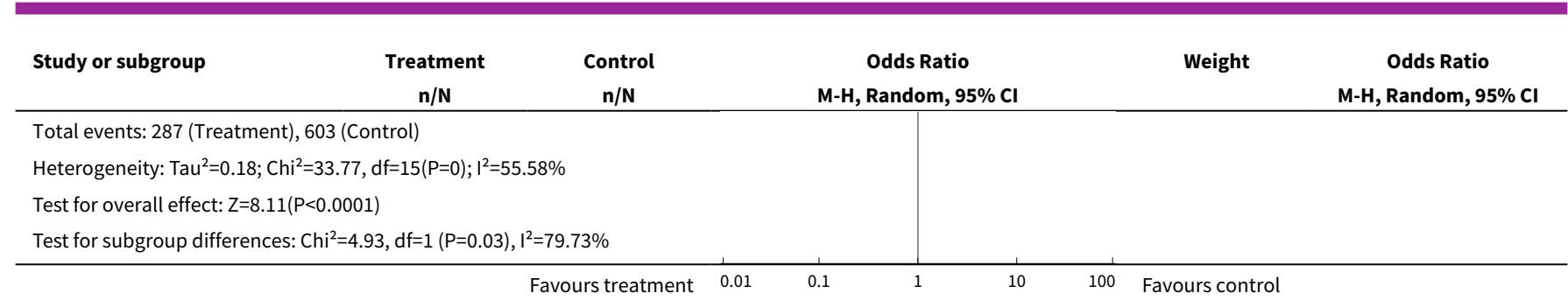

\section{Comparison 2. Topical versus control}

\begin{tabular}{|c|c|c|c|c|}
\hline Outcome or subgroup title & $\begin{array}{l}\text { No. of } \\
\text { studies }\end{array}$ & $\begin{array}{l}\text { No. of } \\
\text { partici- } \\
\text { pants }\end{array}$ & Statistical method & Effect size \\
\hline 1 Overall mortality & 20 & 3016 & Odds Ratio (M-H, Fixed, 95\% Cl) & $0.97[0.82,1.16]$ \\
\hline 1.1 Topical plus systemic versus systemic & 7 & 1233 & Odds Ratio (M-H, Fixed, 95\% Cl) & $0.98[0.73,1.32]$ \\
\hline 1.2 Topical versus no prophylaxis & 13 & 1783 & Odds Ratio (M-H, Fixed, 95\% Cl) & $0.97[0.79,1.20]$ \\
\hline $\begin{array}{l}2 \text { Mortality according to quality of alloca- } \\
\text { tion concealment }\end{array}$ & 20 & 3016 & Odds Ratio (M-H, Fixed, 95\% Cl) & $0.97[0.82,1.16]$ \\
\hline 2.1 Adequate & 2 & 139 & Odds Ratio (M-H, Fixed, 95\% Cl) & $0.64[0.27,1.52]$ \\
\hline 2.2 Not adequate & 18 & 2877 & Odds Ratio (M-H, Fixed, 95\% Cl) & $0.99[0.83,1.18]$ \\
\hline $\begin{array}{l}3 \text { Mortality according to blinding of the } \\
\text { studies }\end{array}$ & 20 & 3016 & Odds Ratio (M-H, Fixed, 95\% Cl) & $0.98[0.82,1.16]$ \\
\hline 3.1 Double-blind & 15 & 2601 & Odds Ratio (M-H, Fixed, 95\% Cl) & $0.99[0.83,1.20]$ \\
\hline 3.2 Open & 5 & 415 & Odds Ratio (M-H, Fixed, 95\% Cl) & $0.88[0.56,1.37]$ \\
\hline 4 RTIs & 18 & 2850 & $\begin{array}{l}\text { Odds Ratio (M-H, Random, 95\% } \\
\mathrm{Cl})\end{array}$ & $0.44[0.31,0.63]$ \\
\hline 4.1 Topical plus systemic versus systemic & 6 & 1115 & $\begin{array}{l}\text { Odds Ratio (M-H, Random, 95\% } \\
\mathrm{Cl} \text { ) }\end{array}$ & $0.79[0.56,1.13]$ \\
\hline 4.2 Topical versus no prophylaxis & 12 & 1735 & $\begin{array}{l}\text { Odds Ratio (M-H, Random, 95\% } \\
\mathrm{Cl} \text { ) }\end{array}$ & $0.34[0.21,0.55]$ \\
\hline $\begin{array}{l}5 \text { RTIs according to quality of allocation } \\
\text { concealment }\end{array}$ & 18 & 2850 & $\begin{array}{l}\text { Odds Ratio (M-H, Random, 95\% } \\
\mathrm{Cl} \text { ) }\end{array}$ & $0.44[0.31,0.63]$ \\
\hline 5.1 Adequate & 1 & 91 & $\begin{array}{l}\text { Odds Ratio (M-H, Random, 95\% } \\
\text { Cl) }\end{array}$ & $0.18[0.04,0.91]$ \\
\hline 5.2 Not adequate & 17 & 2759 & $\begin{array}{l}\text { Odds Ratio (M-H, Random, 95\% } \\
\mathrm{Cl})\end{array}$ & $0.46[0.32,0.66]$ \\
\hline 6 RTIs according to blinding of the studies & 18 & 2850 & $\begin{array}{l}\text { Odds Ratio (M-H, Random, 95\% } \\
\mathrm{Cl})\end{array}$ & $0.44[0.31,0.63]$ \\
\hline
\end{tabular}




\begin{tabular}{lllll}
\hline Outcome or subgroup title & $\begin{array}{l}\text { No. of } \\
\text { studies }\end{array}$ & $\begin{array}{l}\text { No. of } \\
\text { partici- } \\
\text { pants }\end{array}$ & Statistical method & Effect size \\
\hline 6.1 Double-blind & 14 & 2553 & $\begin{array}{l}\text { Odds Ratio (M-H, Random, 95\% } \\
\text { Cl) }\end{array}$ & $0.52[0.36,0.75]$ \\
\hline 6.2 Open & 4 & 297 & $\begin{array}{l}\text { Odds Ratio (M-H, Random, 95\% } \\
\text { Cl) }\end{array}$ & $0.20[0.10,0.41]$ \\
\hline
\end{tabular}

Analysis 2.1. Comparison 2 Topical versus control, Outcome 1 Overall mortality.

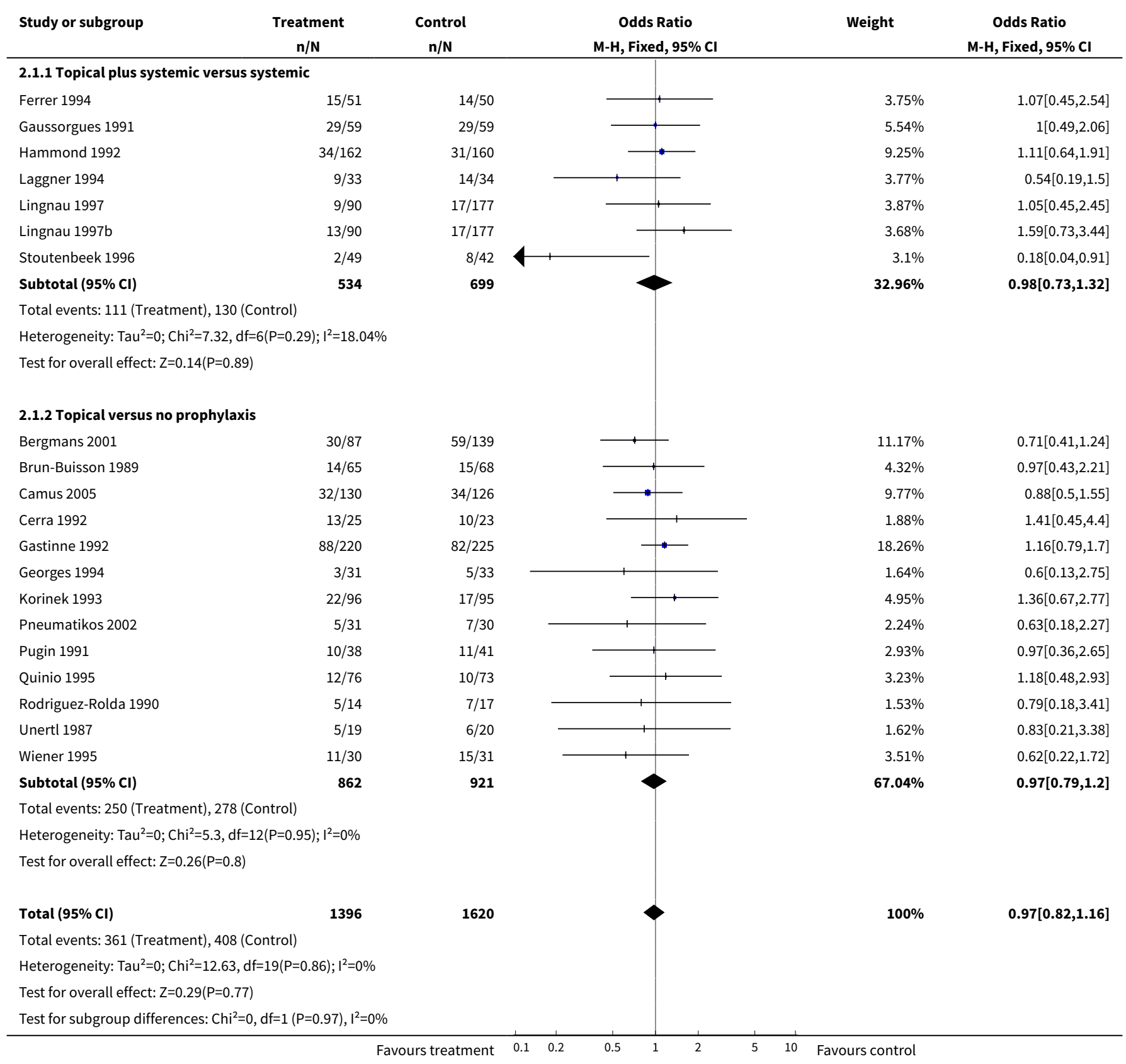


Analysis 2.2. Comparison 2 Topical versus control, Outcome $\mathbf{2}$ Mortality according to quality of allocation concealment.

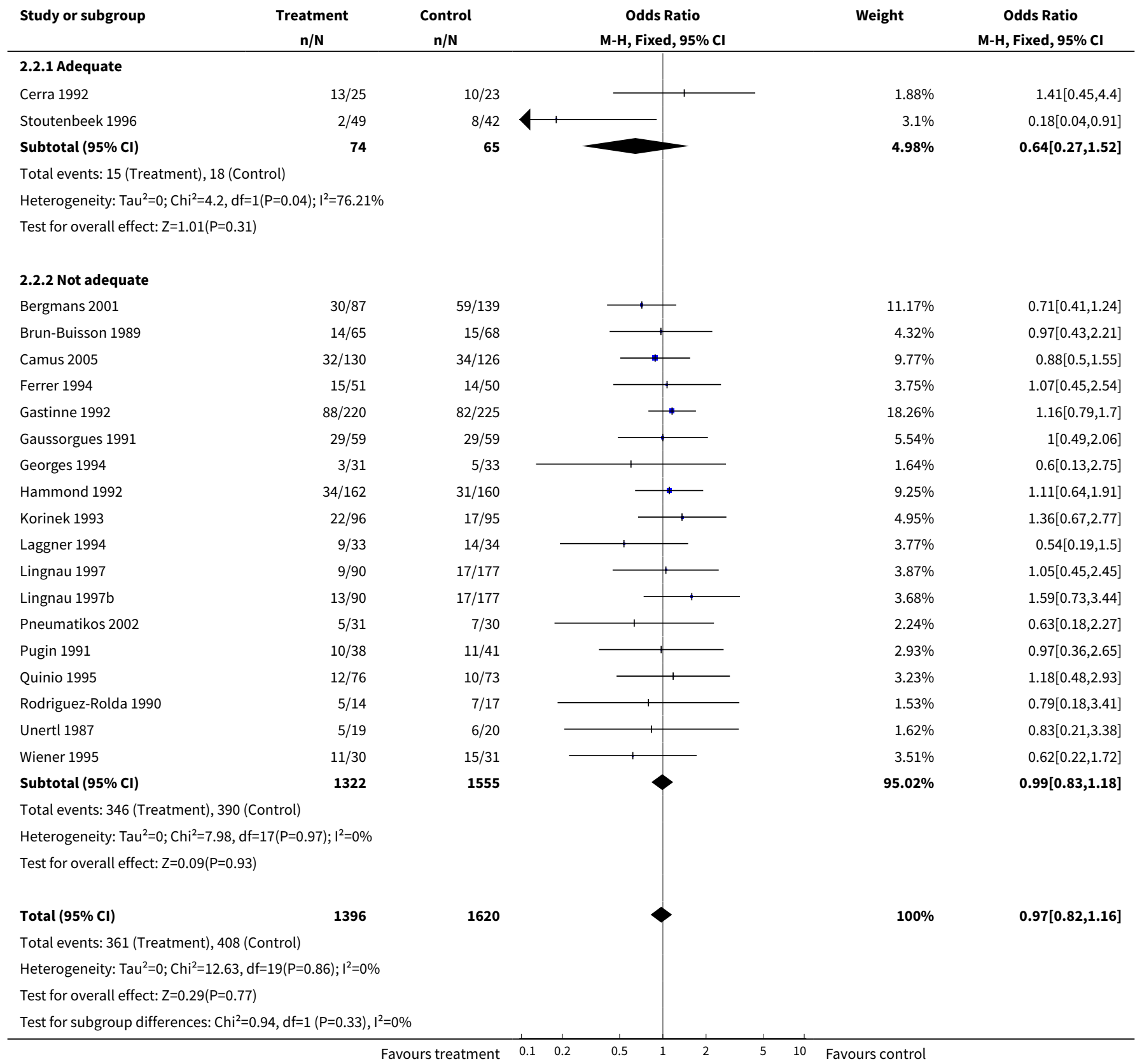

\section{Analysis 2.3. Comparison 2 Topical versus control, Outcome 3 Mortality according to blinding of the studies.}

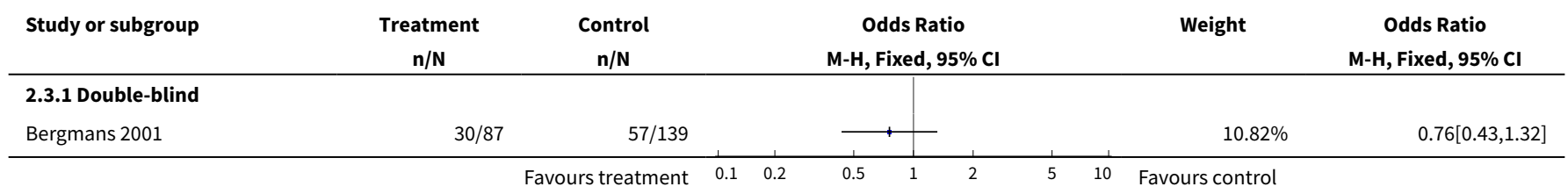




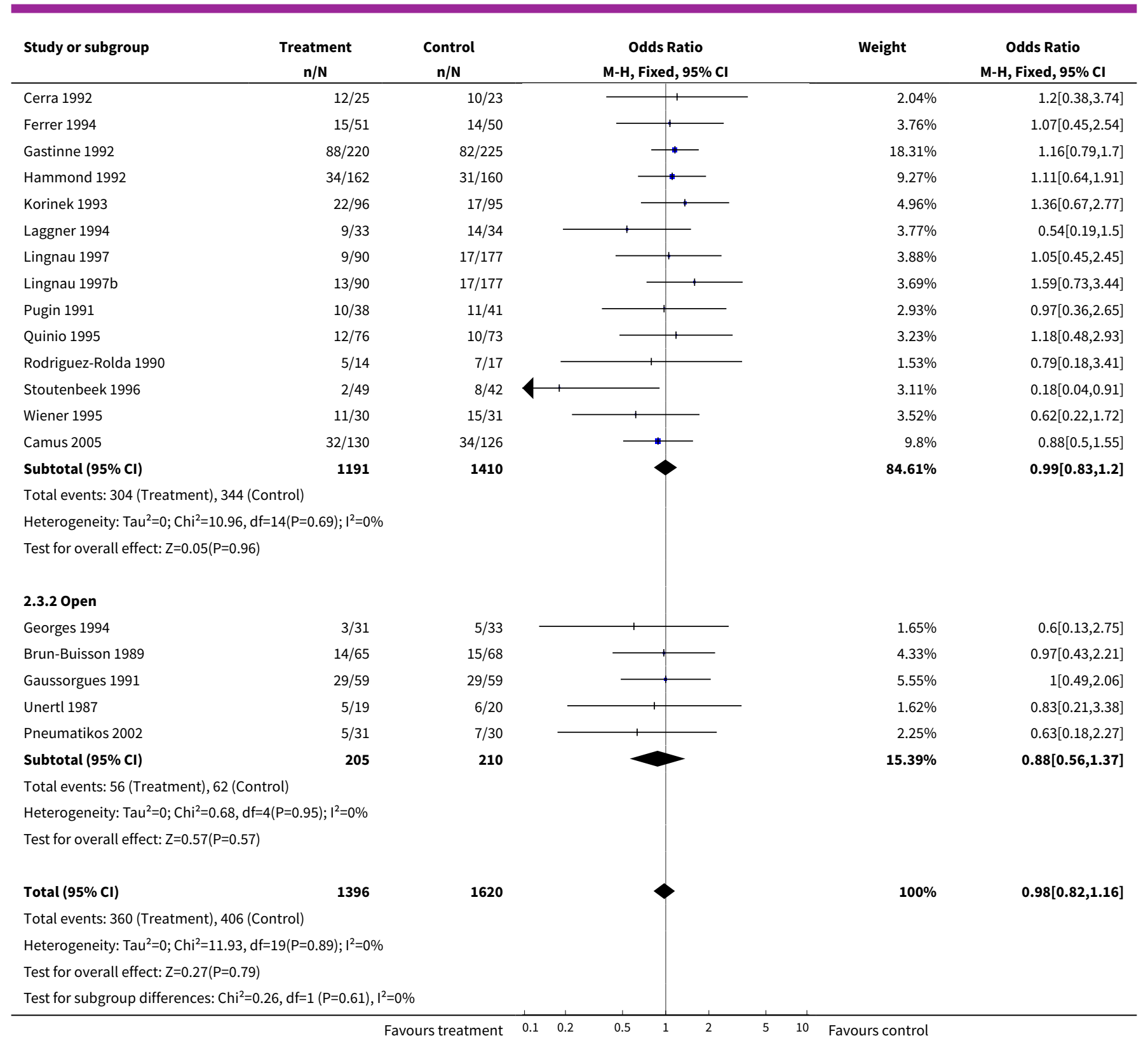

Analysis 2.4. Comparison 2 Topical versus control, Outcome 4 RTIs.

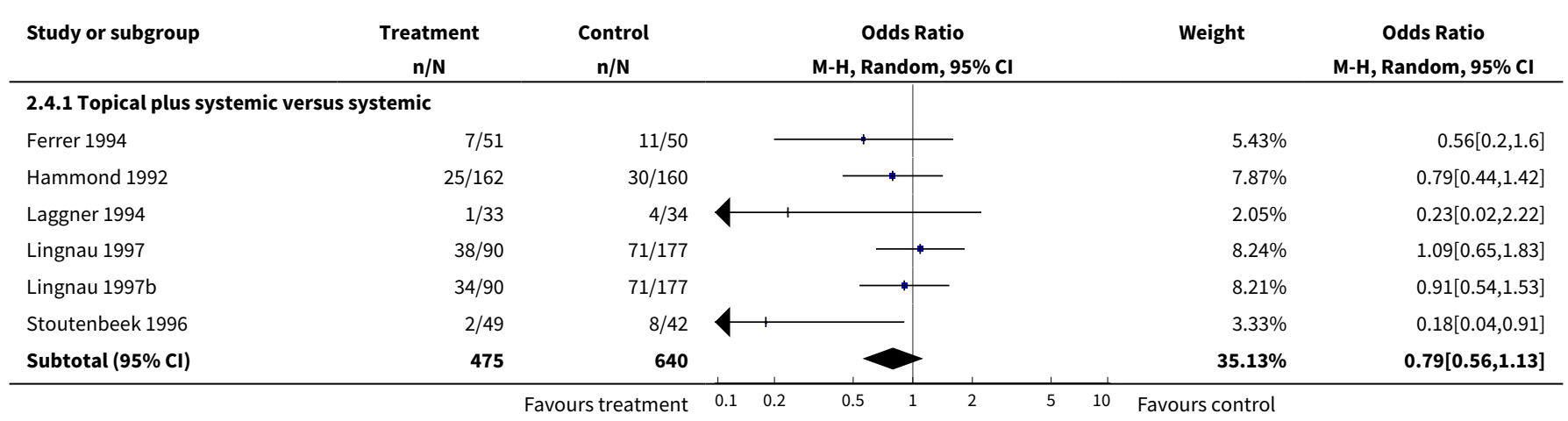




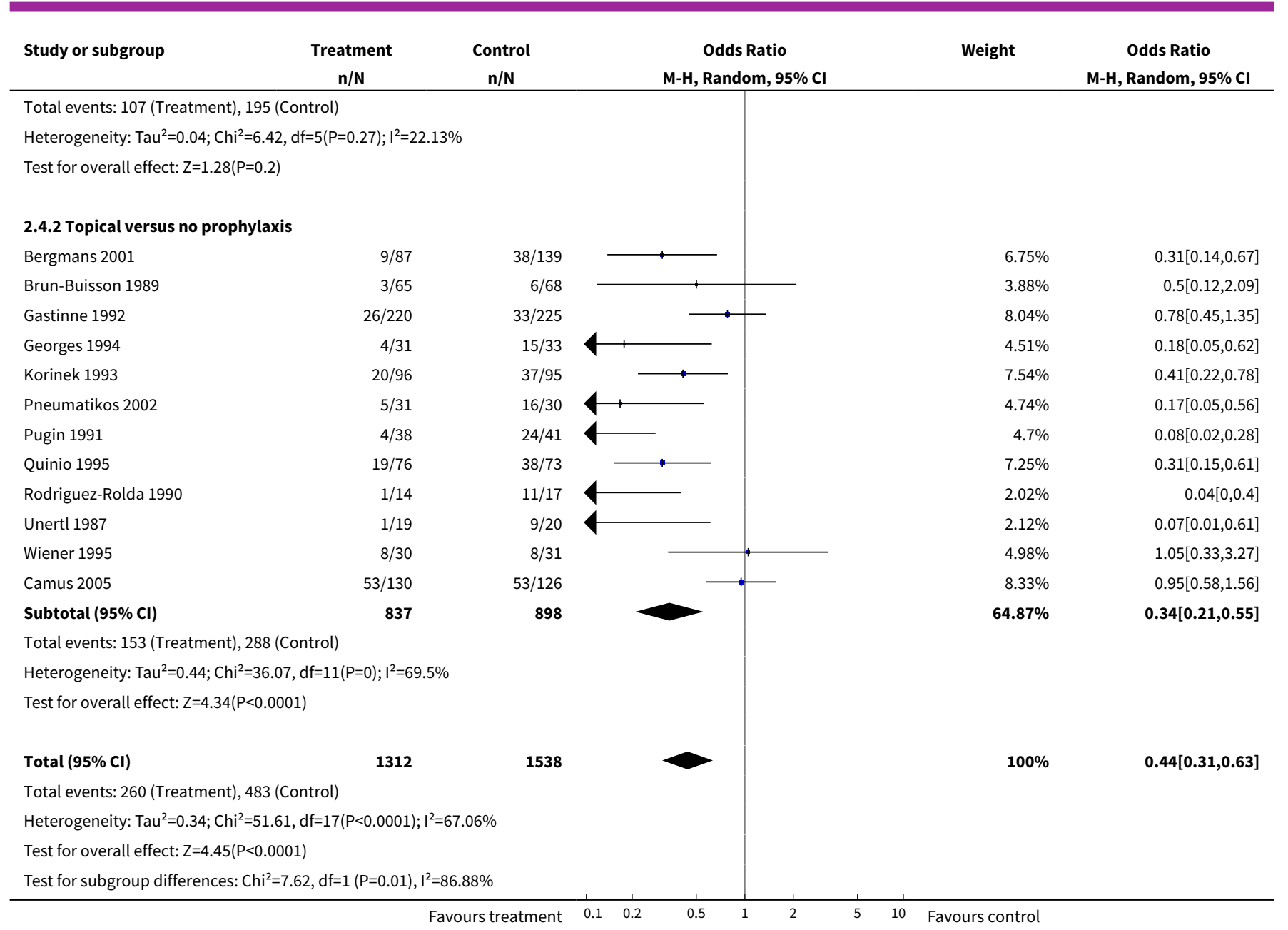

Analysis 2.5. Comparison 2 Topical versus control, Outcome 5 RTIs according to quality of allocation concealment.

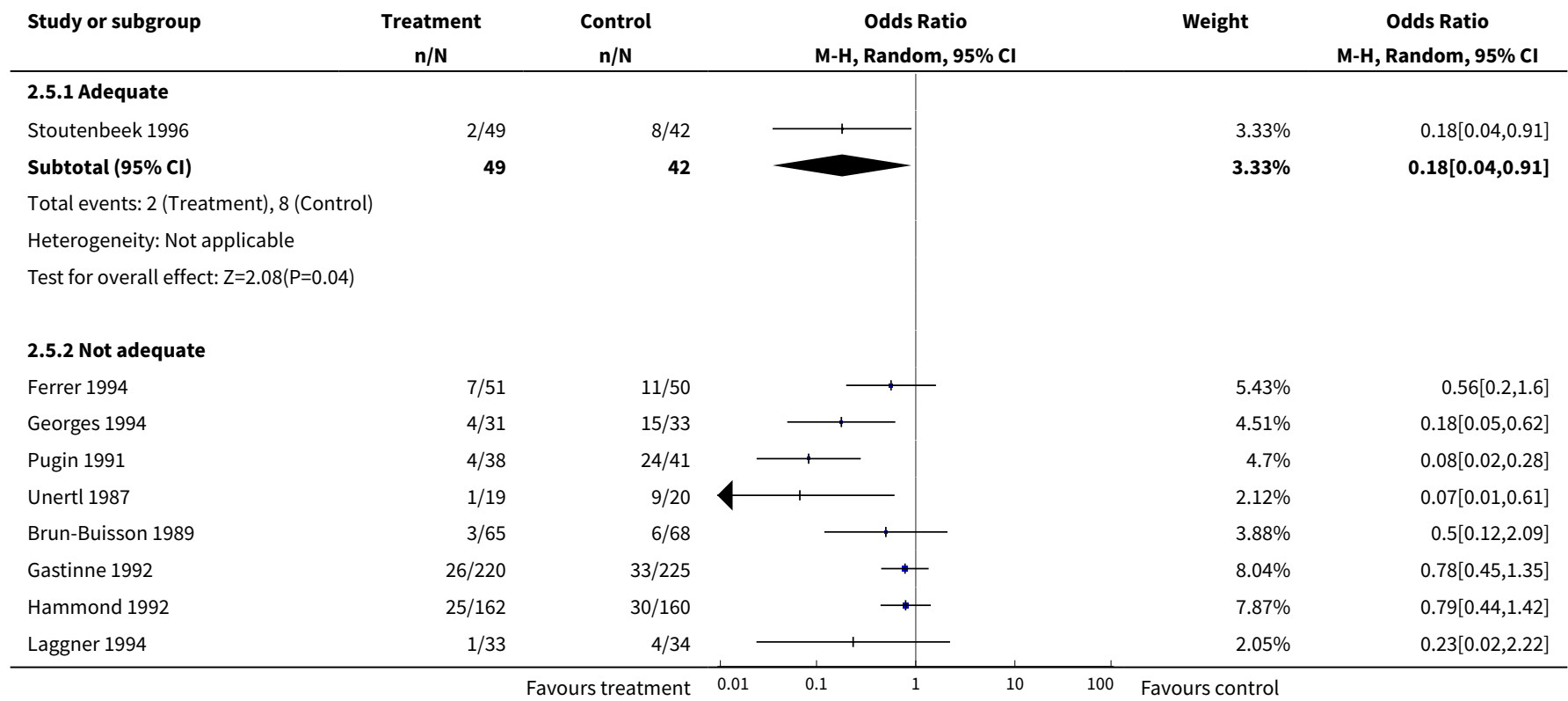




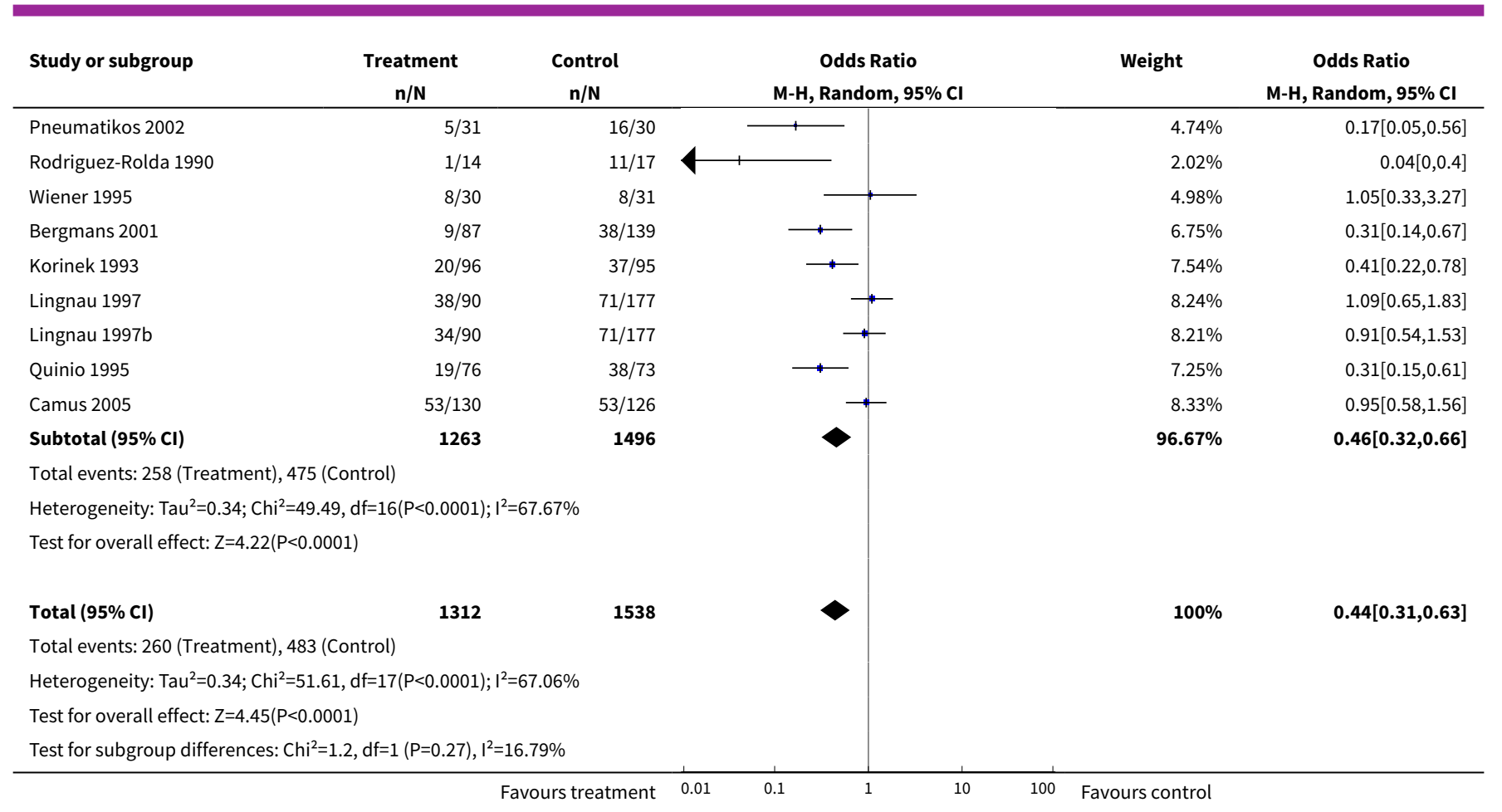

\section{Analysis 2.6. Comparison 2 Topical versus control, Outcome 6 RTIs according to blinding of the studies.}

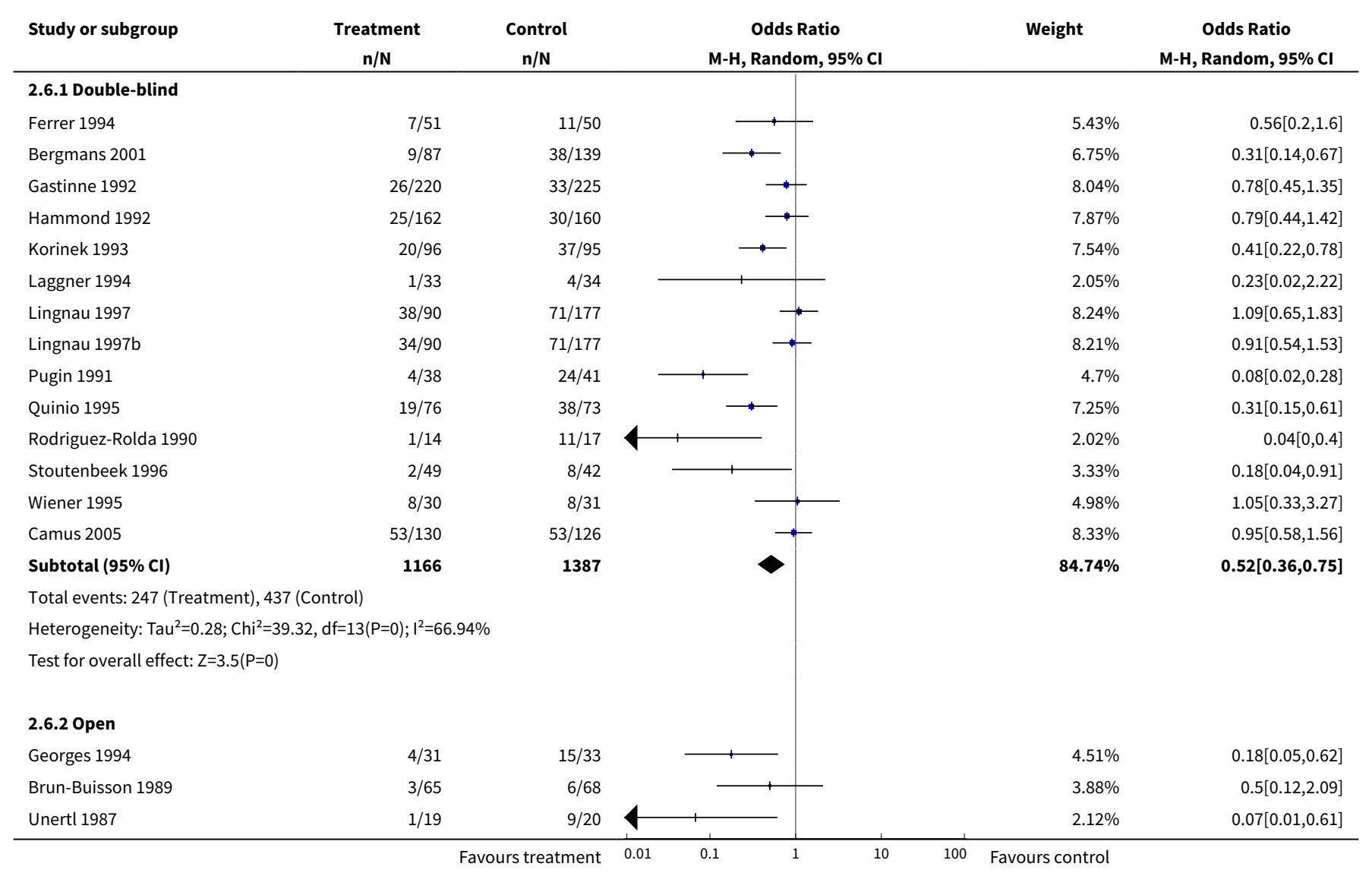




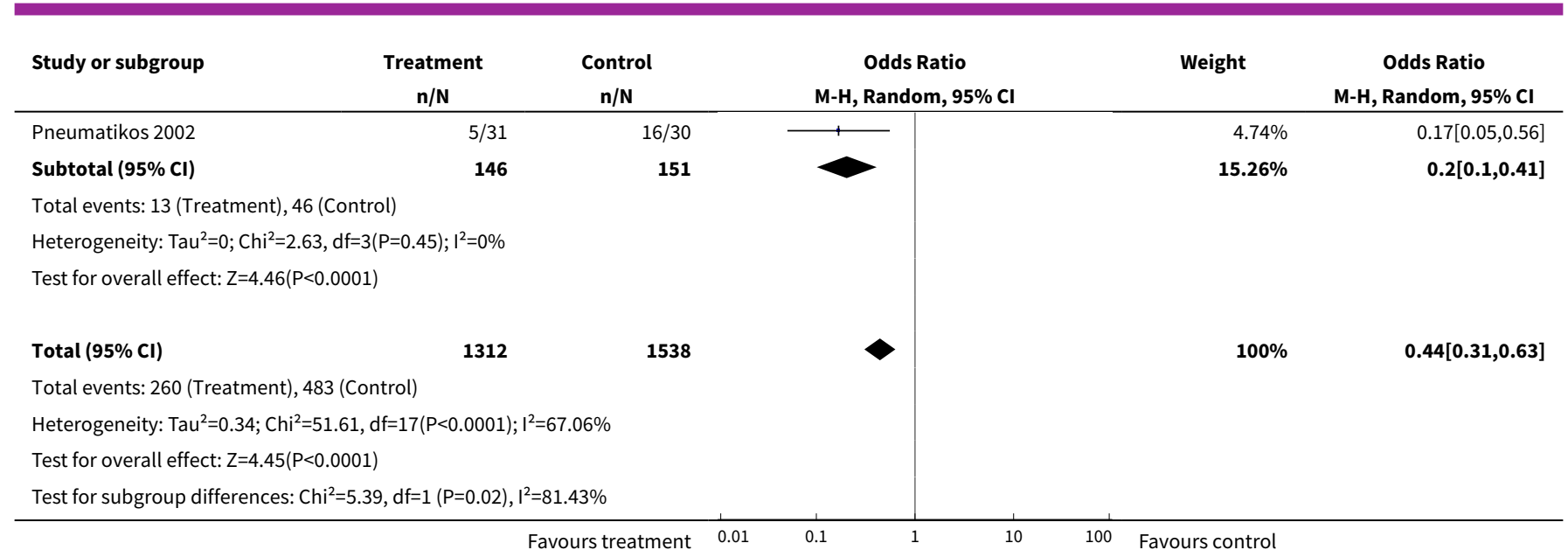

\section{APPENDICES}

\section{Appendix 1. Embase.com search strategy}

1. 'respiratory tract infection'/exp

2. 'respiratory tract infection':ti,ab OR 'respiratory tract infections':ti,ab

3. 'pneumonia'/exp

4. pneumon*:ti,ab

5. hap:ti,ab OR vap:ti,ab

6. bronchopneumonia*:ti,ab OR pleuropneumonia*:ti,ab

7. 'bronchitis'/exp

8. bronchit*:ti,ab OR bronchiolit*:ti,ab

9. 'pharyngitis'/exp

10. pharyngit*:ti,ab

11. 'tracheitis'/exp

12. tracheit*:ti,ab

13. \#1 OR \#2 OR \#3 OR \#4 OR \#5 OR \#6 OR \#7 OR \#8 OR \#9 OR \#10 OR\#11 OR \#12

14. 'intensive care unit'/exp

15. icu:ti,ab OR 'critical care':ti,ab OR 'intensive care':ti,ab OR 'burn unit':ti,ab OR 'burn units':ti,ab OR 'care unit':ti,ab OR 'care units':ti,ab

OR 'recovery room':ti,ab OR 'recovery rooms':ti,ab

16. 'critical illness'/exp

17. 'critically ill':ti,ab OR 'critical illness':ti,ab

18. 'ventilator'/exp

19. ventilator*:ti,ab

20. 'artificial ventilation'/exp

21. respirator*:ti,ab

22. \#14 OR \#15 OR \#16 OR \#17 OR \#18 OR \#19 OR \#20 OR \# 21

23. \#13 AND \#22

24. 'ventilator associated pneumonia'/exp

25. 'ventilator associated pneumonia':ti,ab

26. \#24 OR \#25

27. \#23 OR \#26

28. 'antibiotic prophylaxis'/exp

29. 'antibiotic agent'/exp

30. antibiotic $:$ ti,ab

31. \#28 OR \#29 OR \#30

32. \#27 AND \#31

33. 'randomized controlled trial'/exp

34. 'controlled clinical trial'/exp

35. 'single blind procedure'/exp

36. 'crossover procedure'/exp 
37. random*:ti,ab OR placebo*:ti,ab OR factorial*:ti,ab OR crossover*:ti,ab OR assign*:ti,ab OR allocat*:ti,ab OR volunteer*:ti,ab OR 'double blind':ti,ab OR 'double blinding':ti,ab OR 'double blinded':ti,ab OR 'single blind':ti,ab OR 'single blinded':ti,ab OR 'single blinding':ti,ab 38. \#33 OR \#34 OR \#35 OR \#36 OR \#37

39. \#32 AND \#38

WHAT'S NEW

\begin{tabular}{lll}
\hline Date & Event & Description \\
\hline 20 March 2012 & Amended & Byline citation updated. \\
\hline
\end{tabular}

\section{H ISTORY}

Review first published: Issue 3, 1997

\begin{tabular}{|c|c|c|}
\hline Date & Event & Description \\
\hline 19 May 2011 & New search has been performed & Searches conducted \\
\hline 13 March 2009 & New search has been performed & Searches conducted. \\
\hline \multirow[t]{2}{*}{13 March 2009} & $\begin{array}{l}\text { New citation required but conclusions } \\
\text { have not changed }\end{array}$ & $\begin{array}{l}\text { One study has been included in this update (Camus 2005). Two } \\
\text { studies, whose data were reported in congress proceedings } \\
\text { (Lenhart 1994) and were unpublished (Stoutenbeek 2), have } \\
\text { been replaced by Krueger } 2002 \text { and Stoutenbeek } 2007 \text { which are } \\
\text { their published versions in peer-reviewed journals. }\end{array}$ \\
\hline & & $\begin{array}{l}\text { One study (Jacobs 1995) included in the previous version of this } \\
\text { review as a personal contact with the principal investigator, has } \\
\text { been excluded due to lack of feedback from the trial author. To } \\
\text { date, this study has not been published. }\end{array}$ \\
\hline 30 January 2008 & Amended & Converted to new review format \\
\hline 5 September 2003 & New search has been performed & Searches conducted. Updated review published Issue 4, 2002 \\
\hline 5 December 1999 & New search has been performed & Searches conducted. Review published Issue 3, 1997 \\
\hline 5 December 1995 & New search has been performed & Searches conducted. Updated review published Issue 1, 2004 \\
\hline
\end{tabular}

\section{CONTRIBUTIONS OF AUTHORS}

Alessandro Liberati prepared the protocol and review, oversaw the data collection and critical appraisal of studies, updated the review and prepared the final version of the manuscript.

Roberto D'Amico prepared the protocol and review, oversaw the data collection and critical appraisal of studies, carried out the statistical analysis, updated the review and prepared the final version of the manuscript.

Luca Brazzi collaborated in the preparation of the protocol, the identification of trials and their critical appraisal.

Valter Torri collaborated in the preparation of the protocol and the statistical analysis.

Silvia Pifferi collaborated in the identification and critical appraisal of trials.

Elena Parmelli collaborated in the update of the review.

\section{DECLARATIONSOF INTEREST}

None known. 


\section{SOURCES OF SUPPORT}

\section{Internal sources}

- Italian Cochrane Centre, Italy.

\section{External sources}

- No sources of support supplied

\section{INDEX TERMS}

\section{Medical Subject Headings (MeSH)}

*Antibiotic Prophylaxis; *Critical Care; *Hospital Mortality; Anti-Bacterial Agents [therapeutic use]; Cross Infection [mortality] [ ${ }^{\star}$ prevention \& control]; Randomized Controlled Trials as Topic; Respiratory Tract Infections [mortality] [ ${ }^{\star}$ prevention \& control]

\section{MeSH check words}

Adult; Humans 